
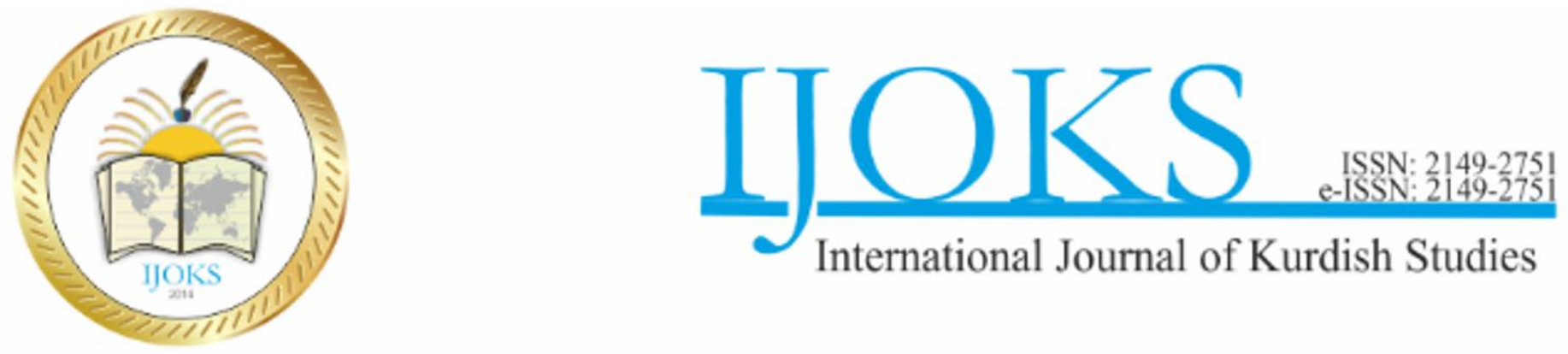

Article

International Journal of Kurdish Studies

6 (2), pp. 222- 243

http://ijoks.com

\title{
Concepts of Nationalism and Rights of Citizenship in the Ottoman State and Nations of the Empire 1789 - 1908
}

Fahir A. MIRHAN ${ }^{1}$ (D)

Received: May 31, 2020

Reviewed: June 26, 2020

Accepted: Jul 15, 2020

\begin{abstract}
From ancient times, civil conflicts have competed for the sake of expanding their hegemony of power over spheres such as the economic, political, religious, racial, and social. These conflicts compounded with nationalist thought in general were seen as dimensions of wars and conflicts in the 18th, 19th and 20th centuries. Against the historical background of the emergence of nationalistic concepts and concepts of the rights of citizens in nationstates, this study delves into the reasons for the Ottoman mindset and movements. Ottoman concepts in the Ottoman state affected the life-style and thought of individual nations within the Empire; the resultant clash and conflicts with external regional aspirations then played a role in the rise of nationalistic thought in the Ottoman state and nations of the Empire.
\end{abstract}

Keywords: Ottoman nationalism, Ottoman Empire, Ottoman concepts of citizenship, Expansion of the hegemony of power, Linguistic verifications

\section{Recommended citation:}

Mirhan, F.A. (2020). Concepts of Nationalism and Rights of Citizenship in the Ottoman State and Nations of the Empire 1789 - 1908. International Journal of Kurdish Studies 6 (2), 222 - 243,

DOI: https://doi.org/10.21600/ijoks. 745840

\footnotetext{
${ }^{1}$ Ph.D. Candidate, Sakarya University, Institute of Social Sciences, Department of History, Academic Staff at Soran University, KRG, Iraq, E-mail: Fa.mirhan@yahoo.com / Fakhir.ababakr@soran.edu.iq ORCID ID: 0000-0001-9315-2713
} 


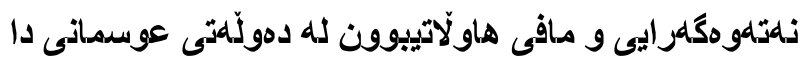 \\ 1908 - 1789 \\ فاخز عالى عبابكز ميزخان \\ قوتابى دكتورا له زانكوّى سدكاريا / ماموستاى باريدهدهر له زانكوّى سوّران
}

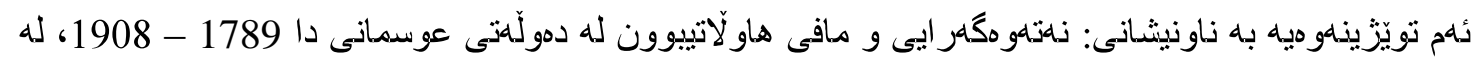

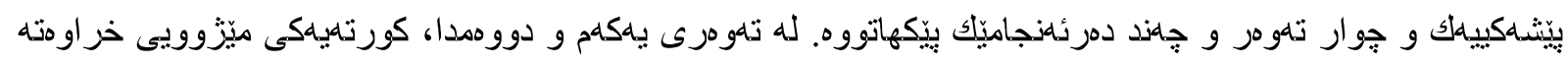

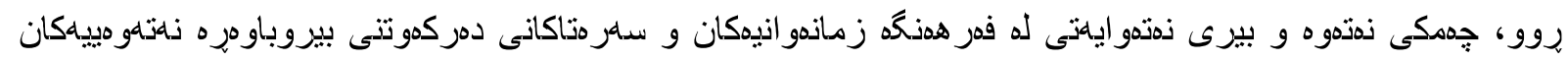

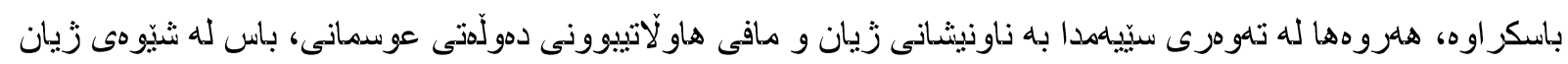

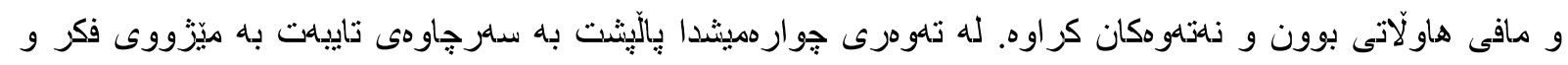

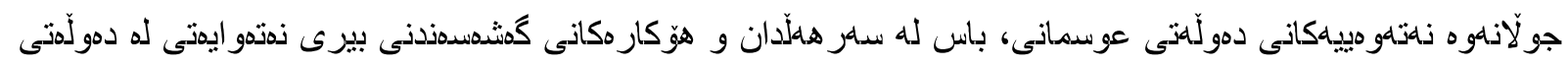

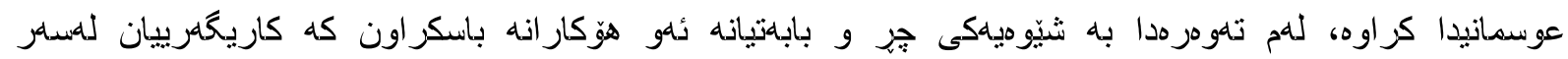

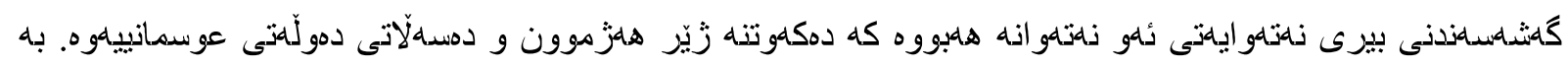

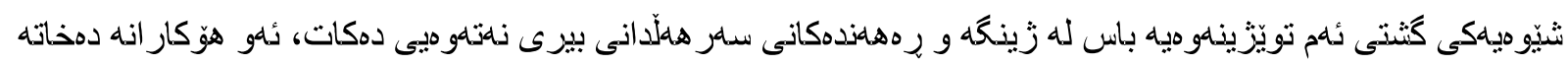

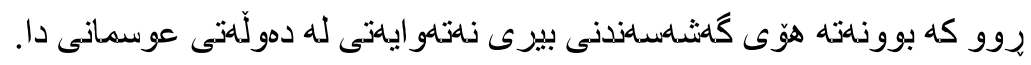

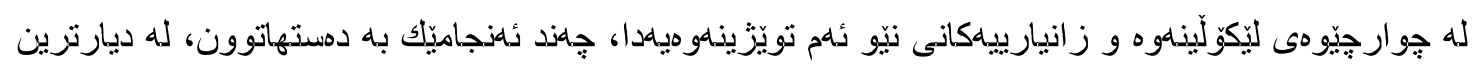

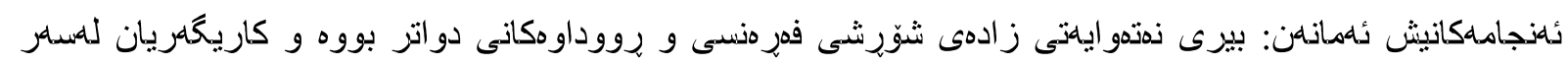

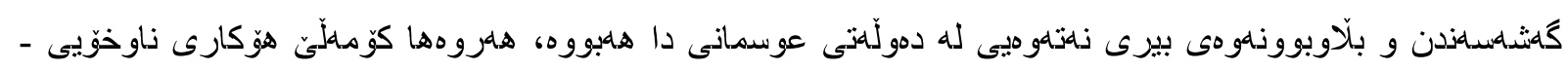

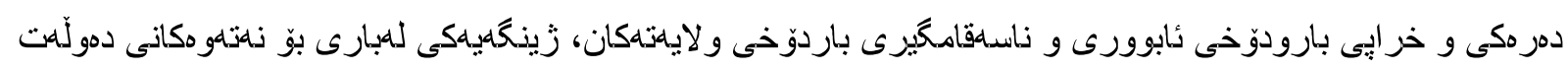

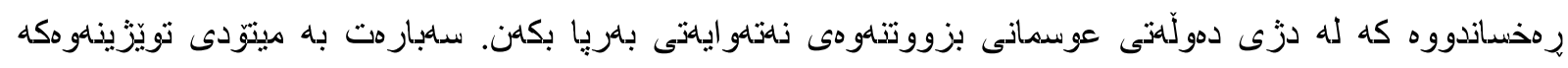

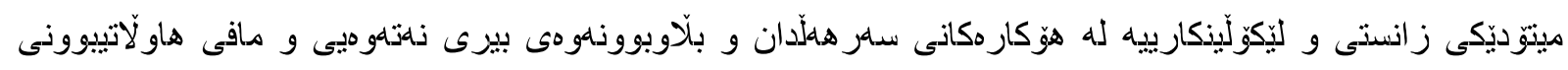

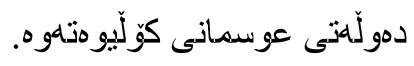

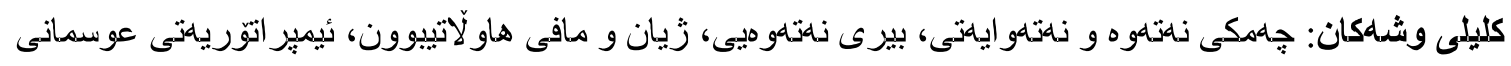




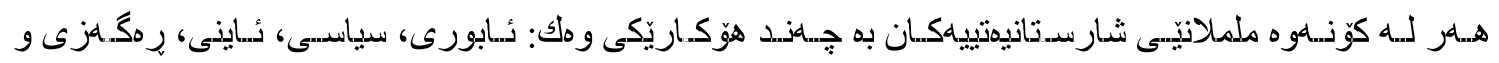

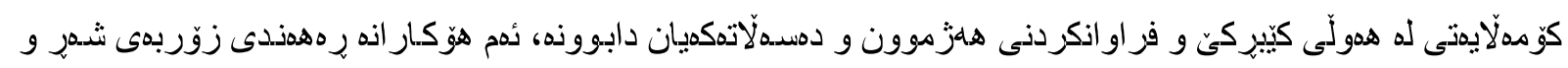

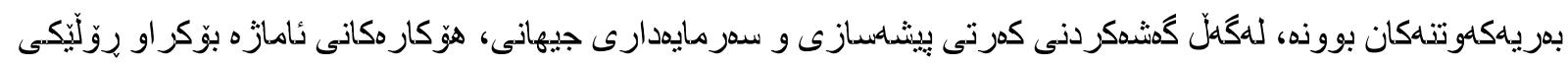

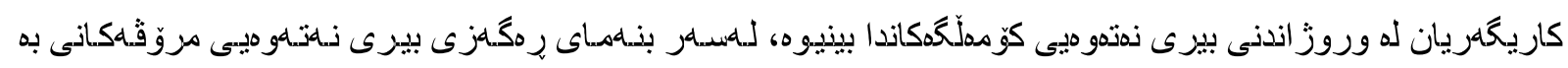

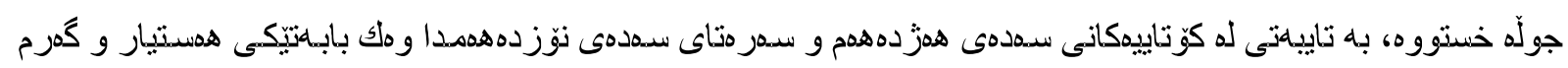

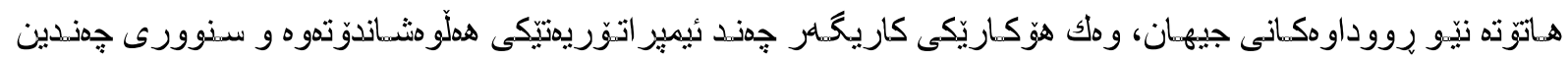

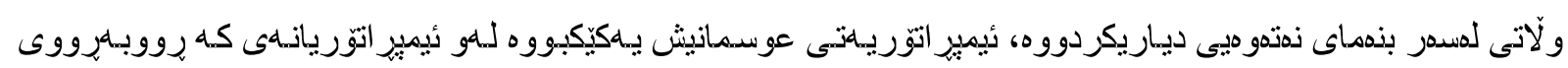

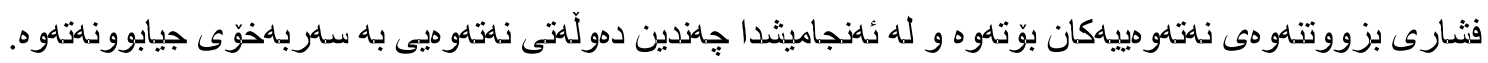

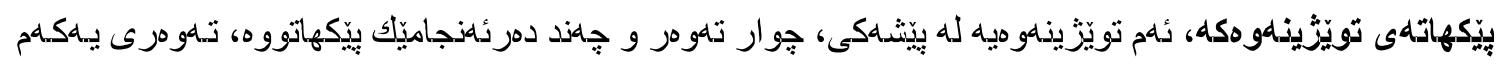

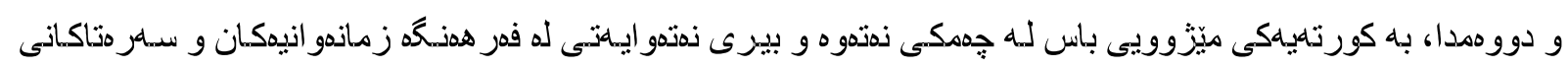

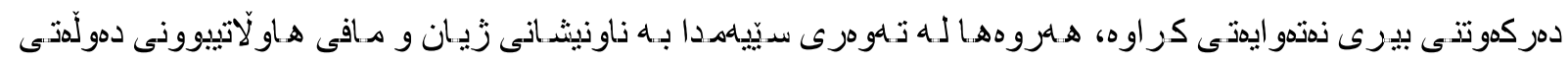

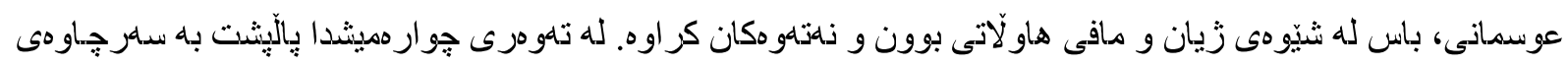

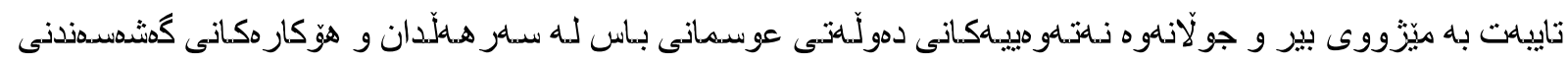

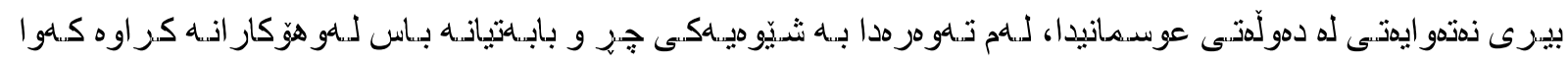

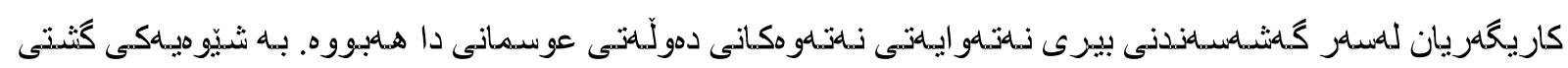

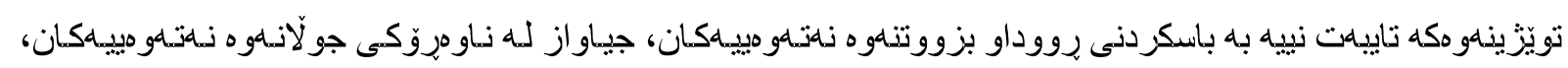

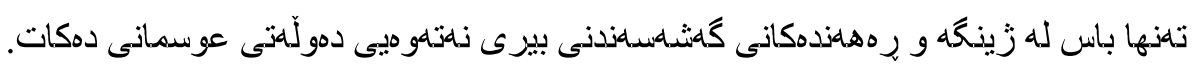

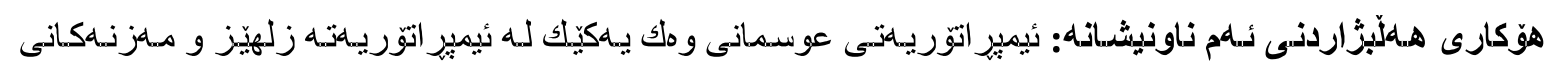

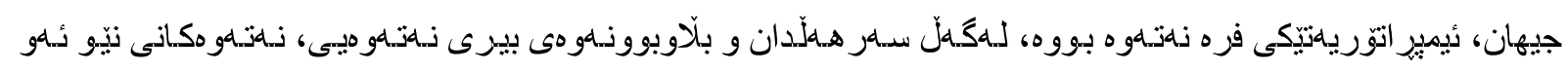

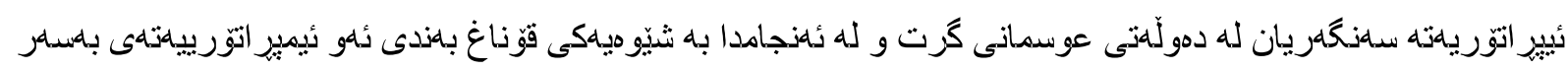

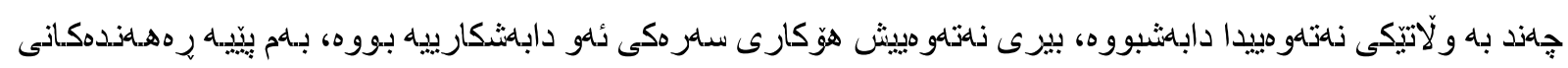

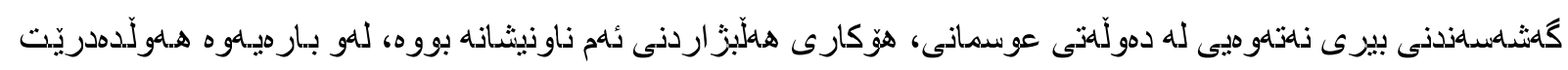

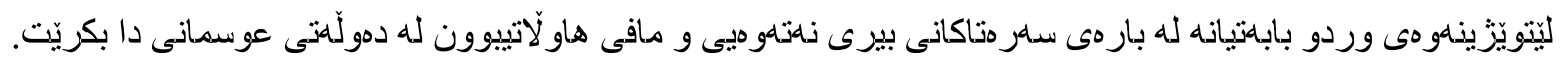

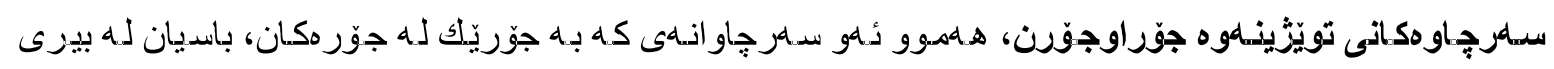

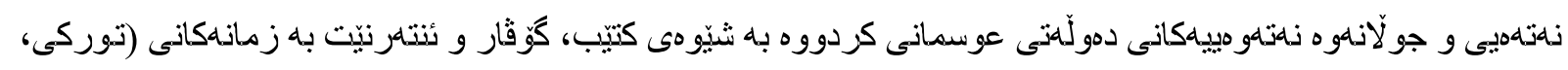

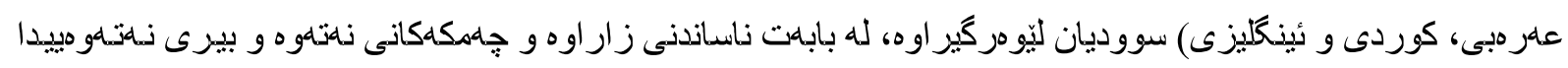

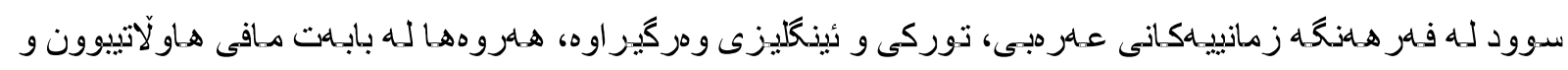

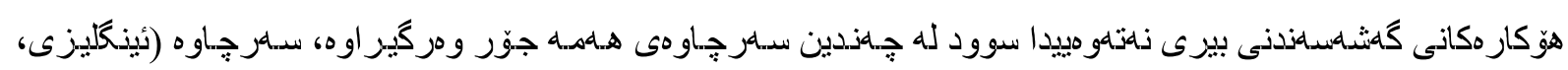

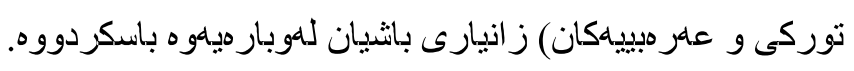




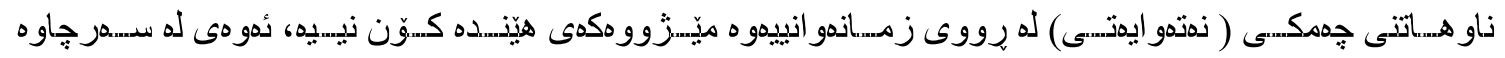

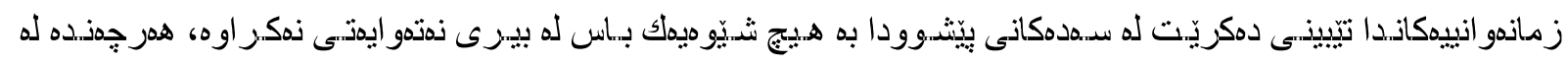

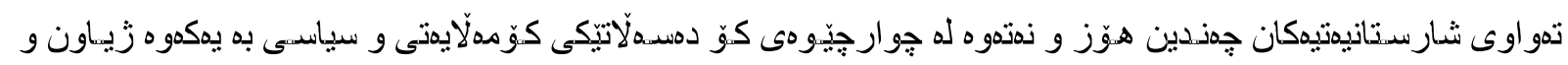

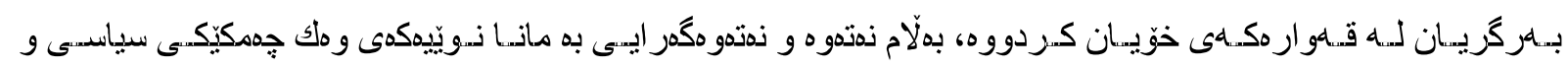

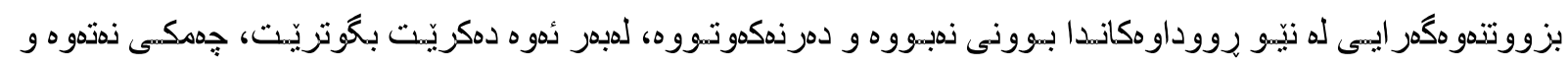

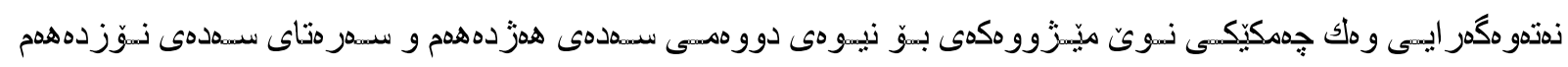

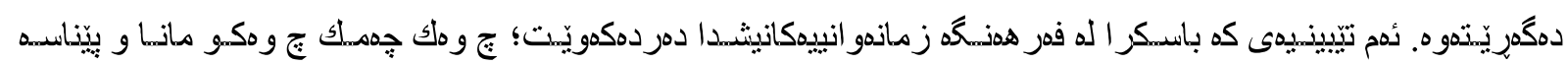

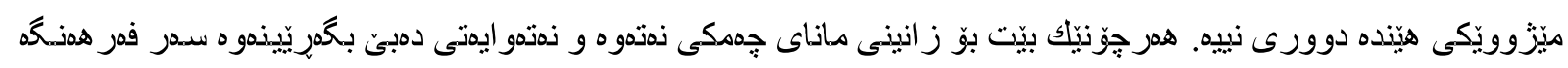

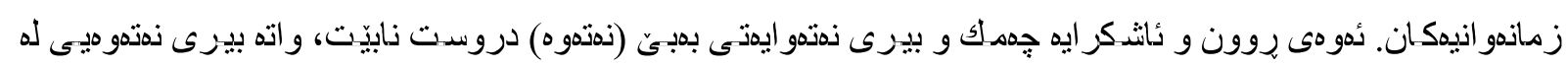

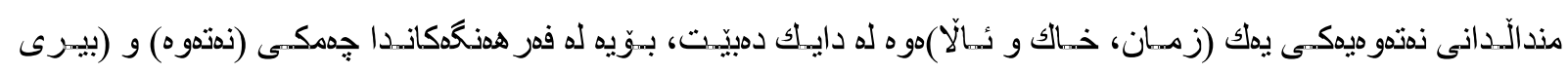

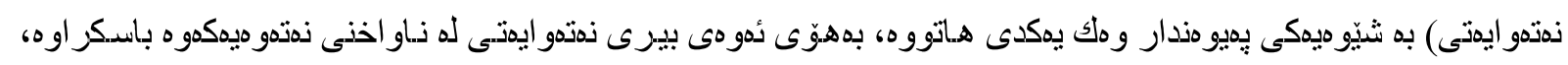

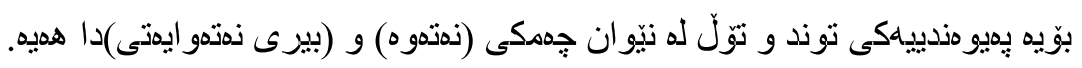

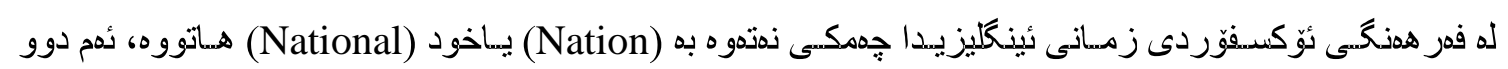

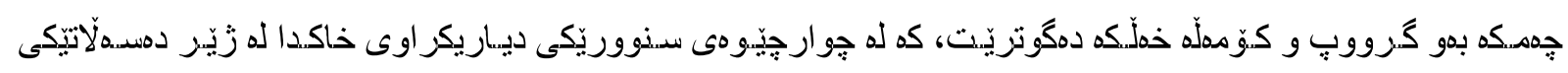

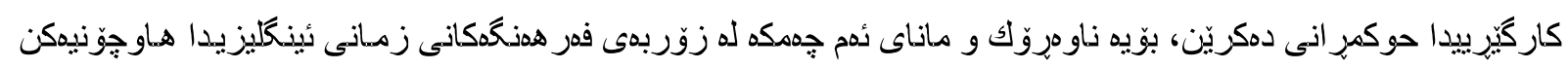

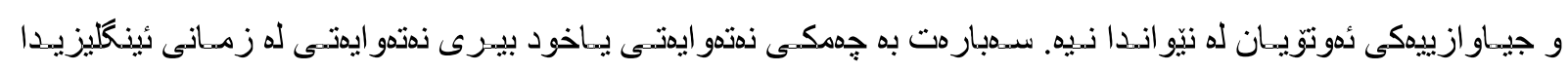
(Nationalism)

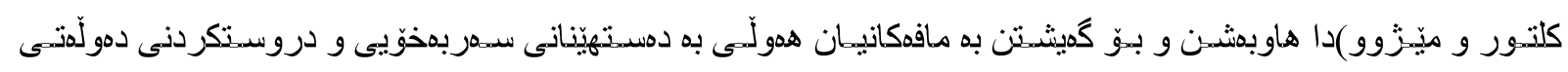

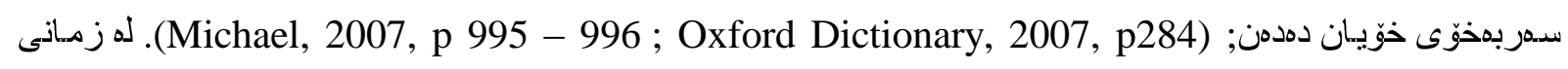

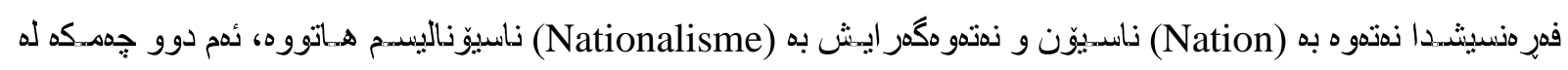

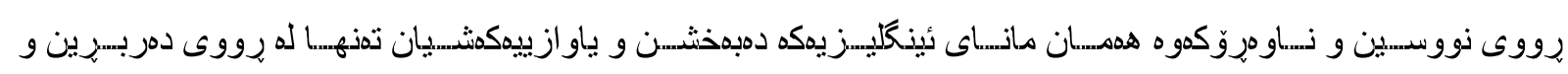

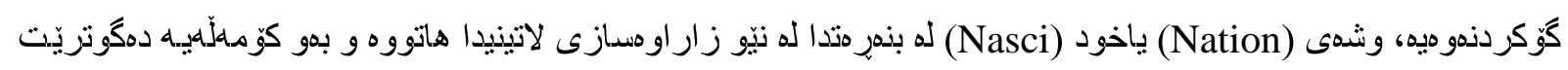

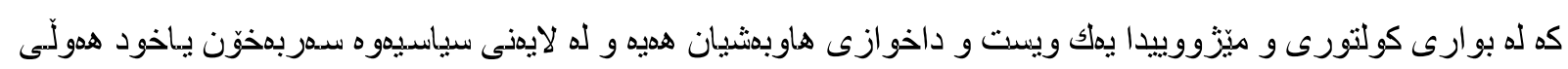

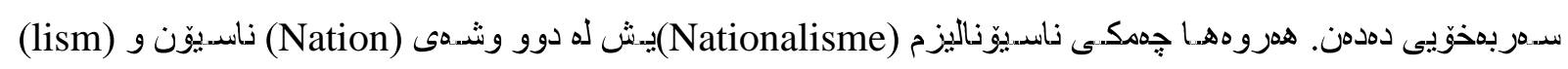

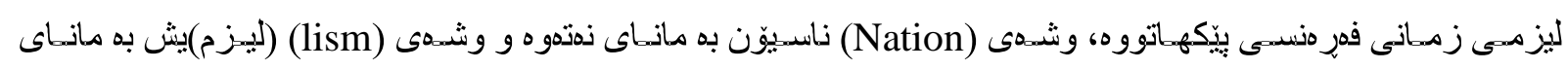

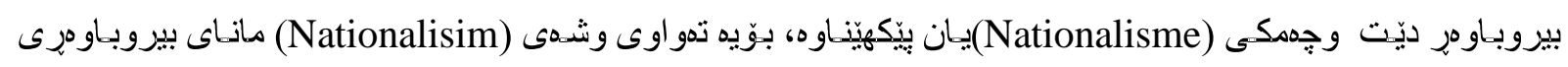

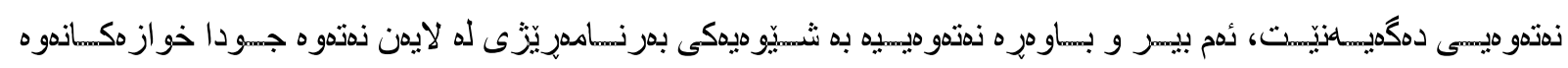

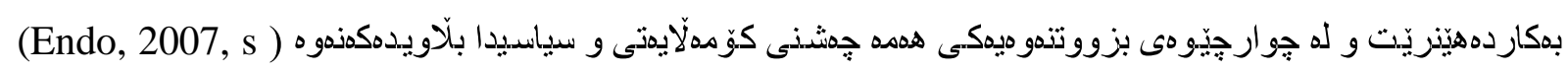

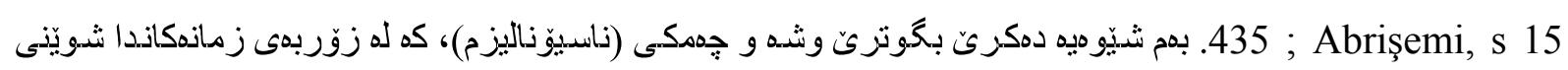

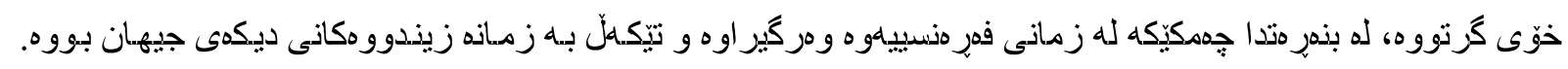

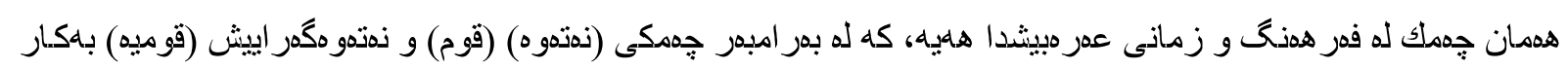

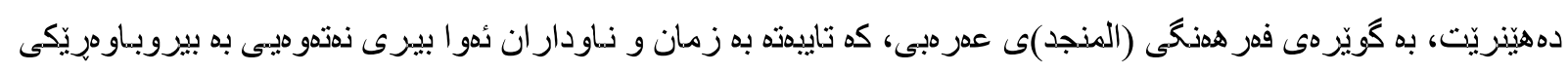




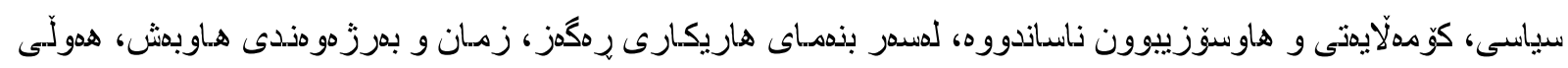

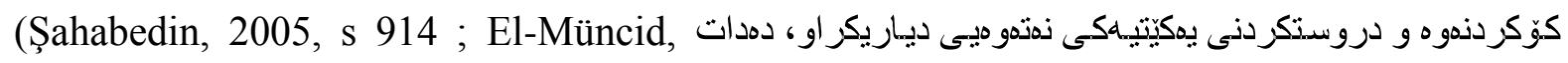

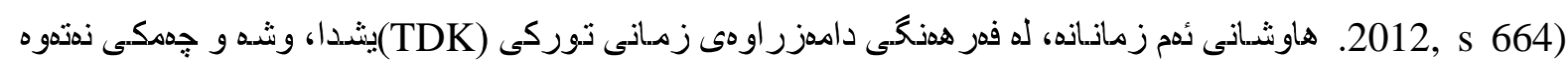

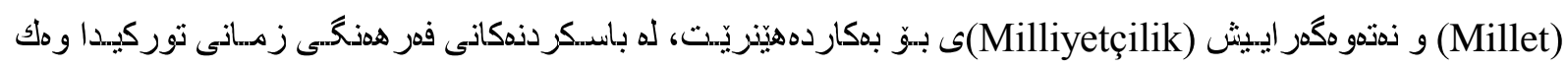

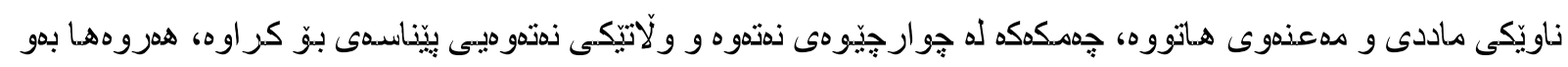

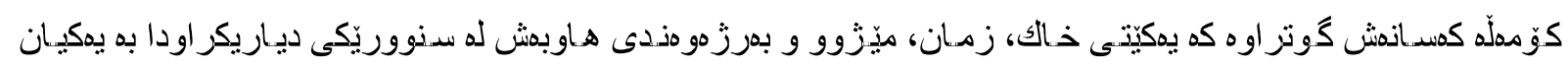

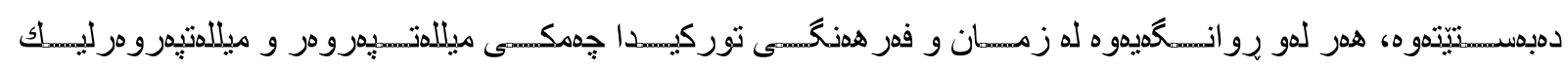

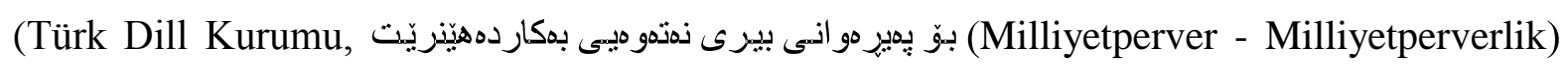

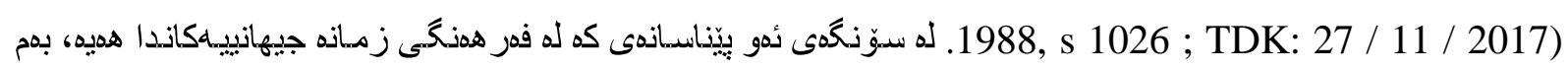

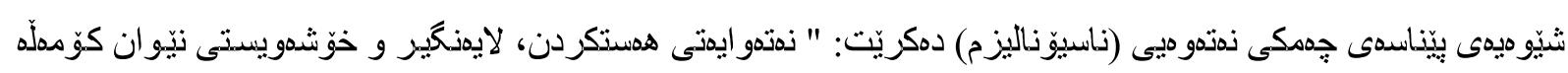

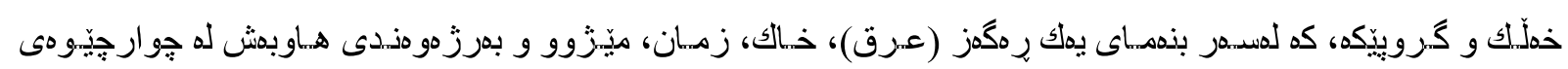

سذووريّكى دياريكر اوى ولّاتيّكدا به بهكيان دمبهستيّتهوه.

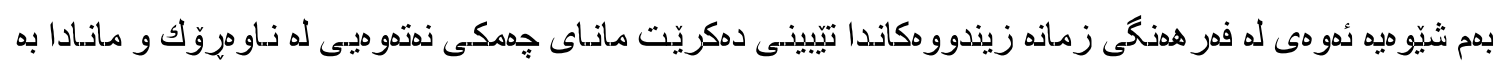

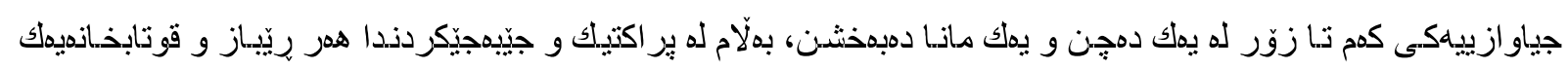

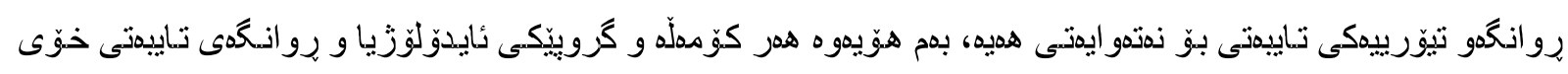

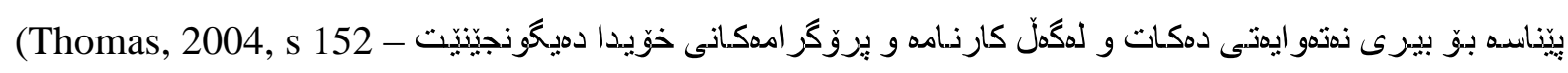

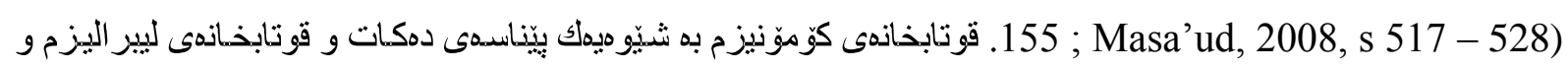

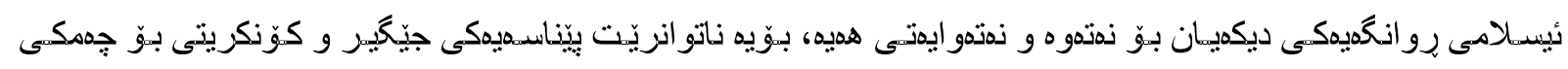

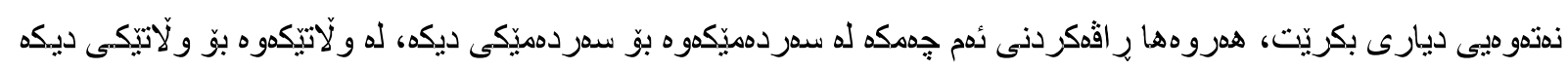

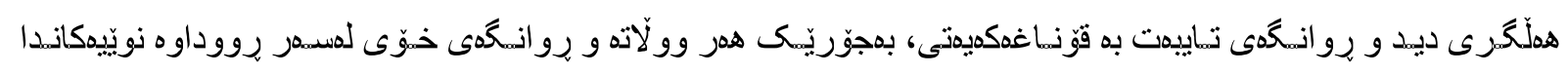

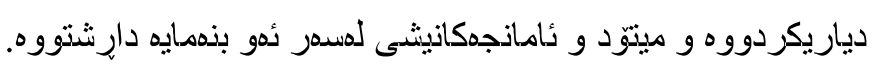

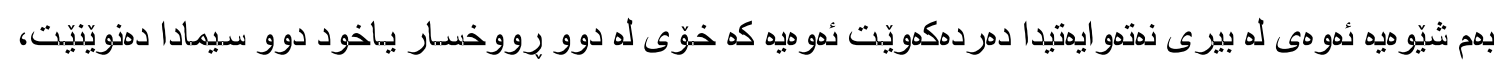

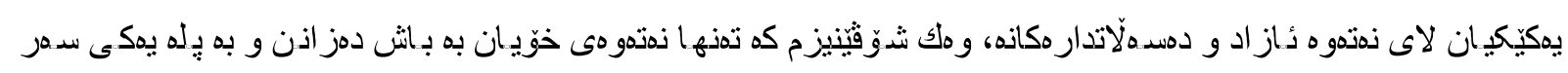

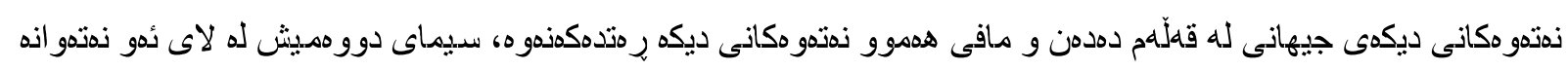

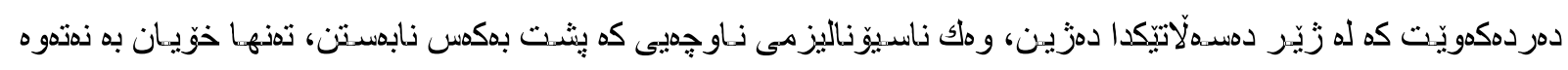

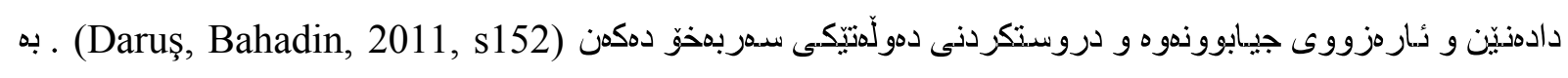

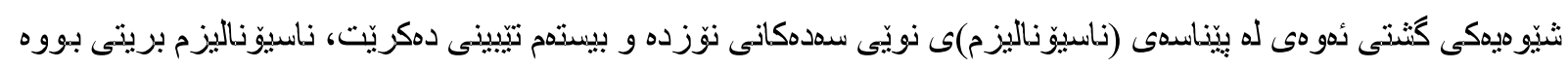

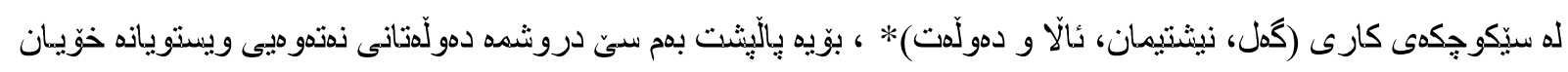

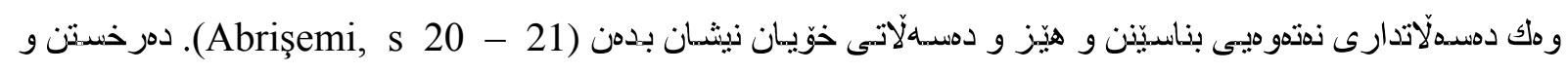

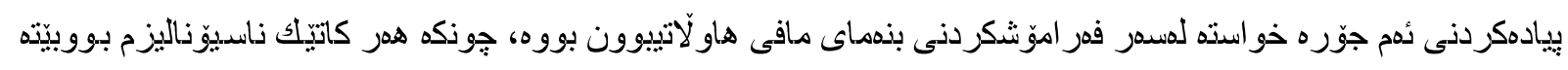

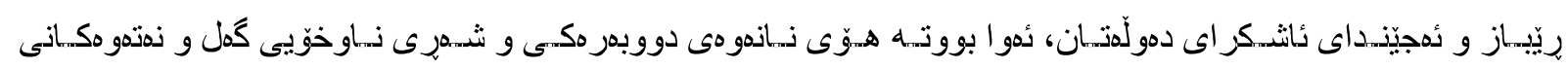

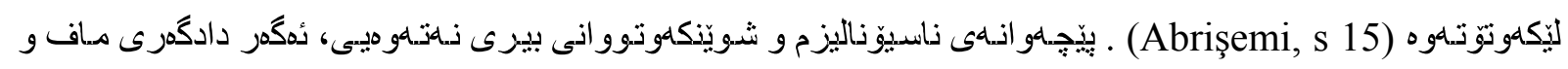

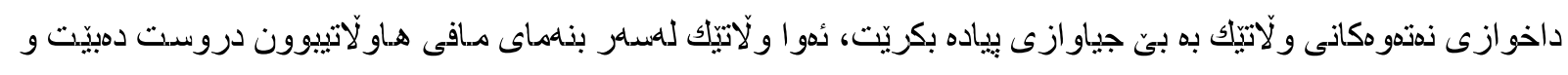

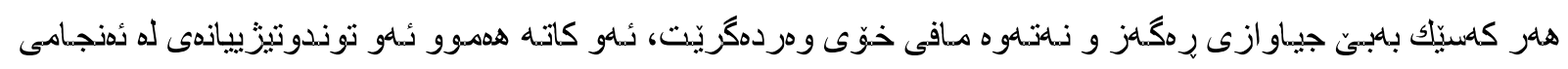




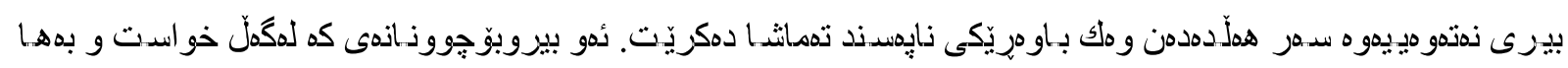

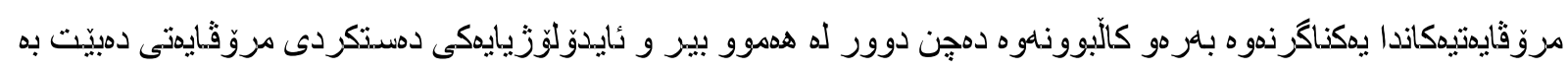

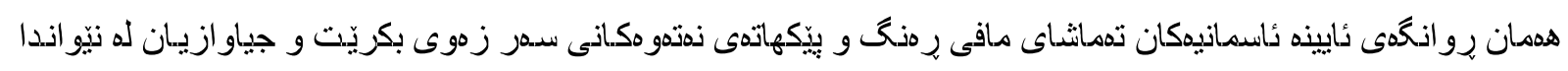

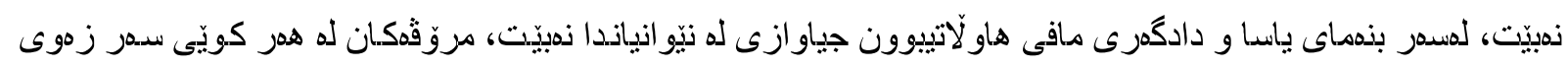

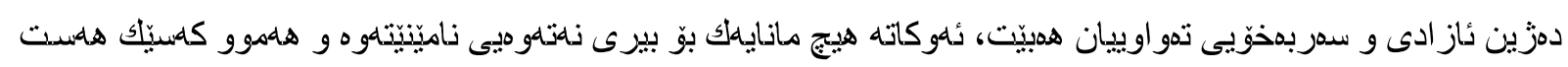
به مافه سروشتييهكانى خوّى ددكات.

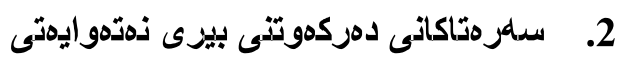

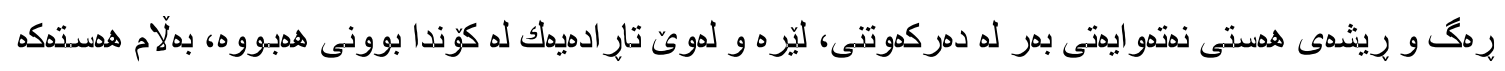

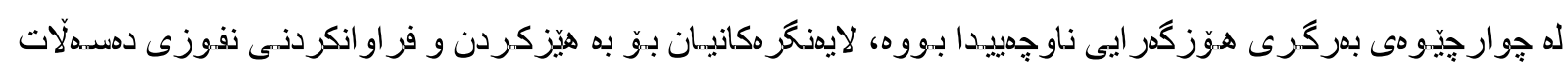

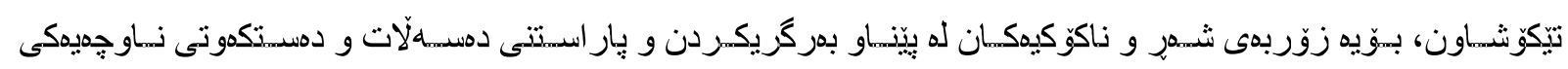

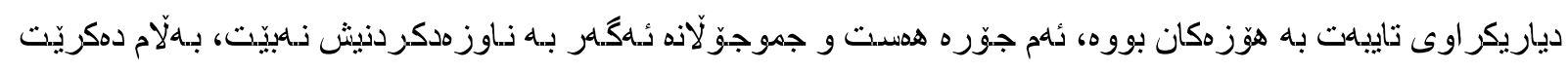

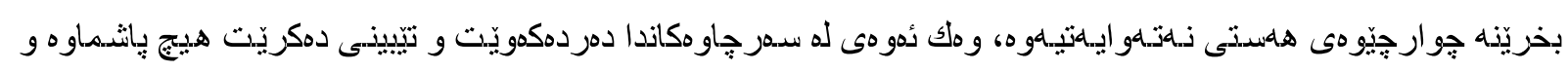

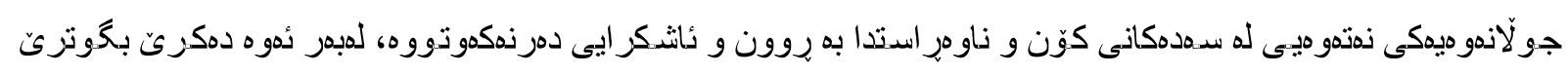

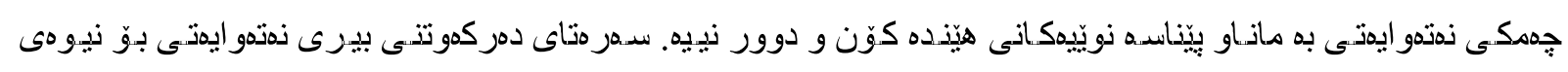

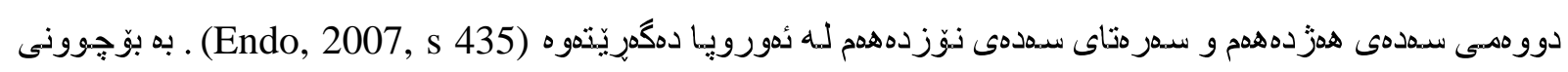

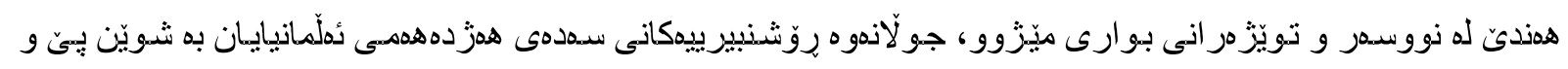

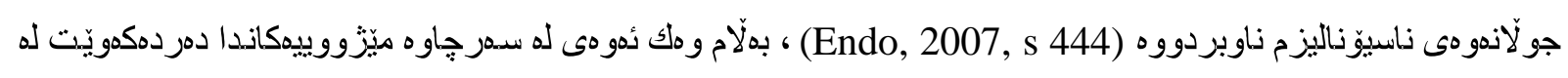

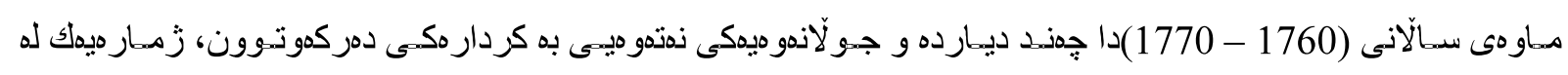

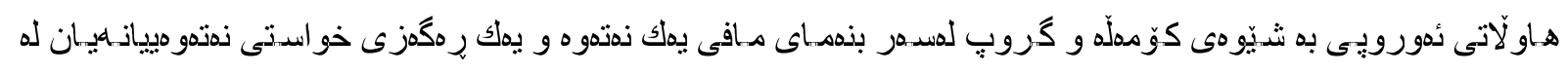

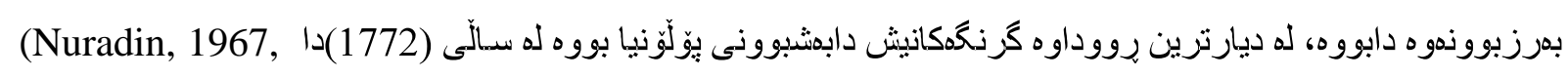

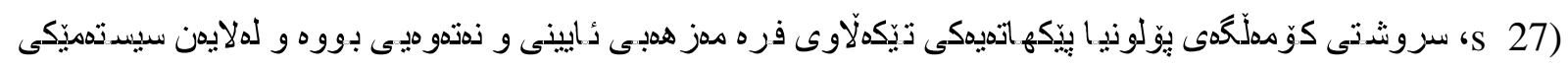

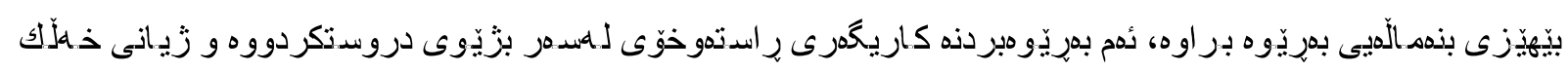

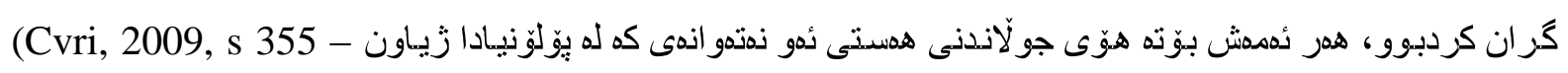

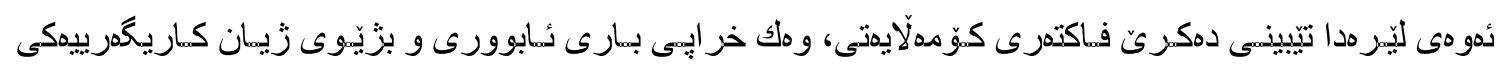

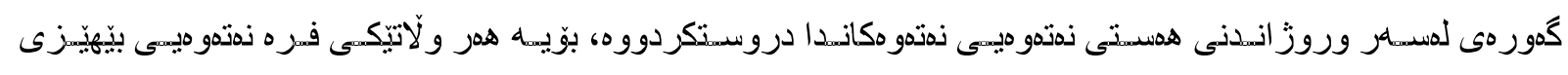

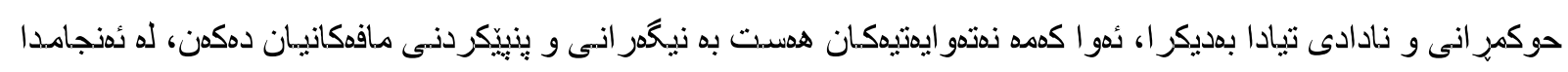

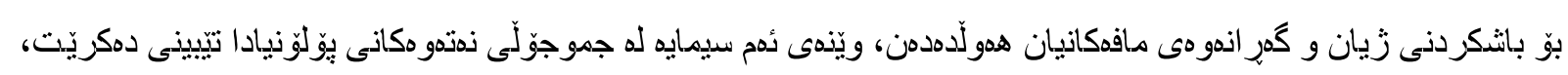

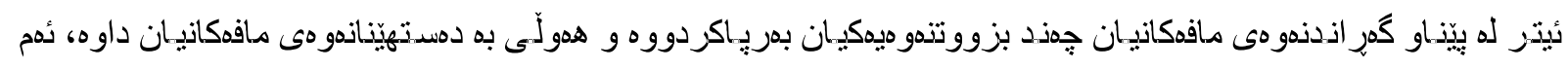

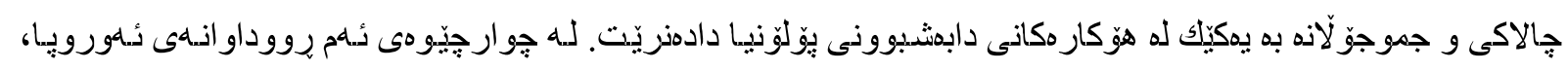

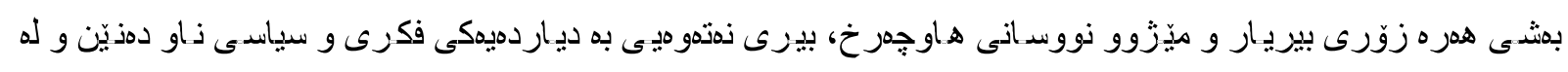

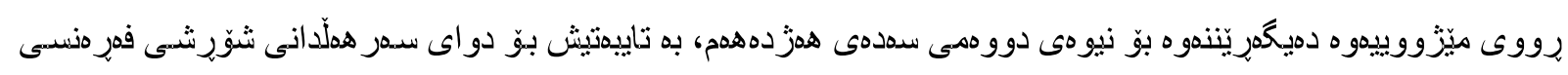




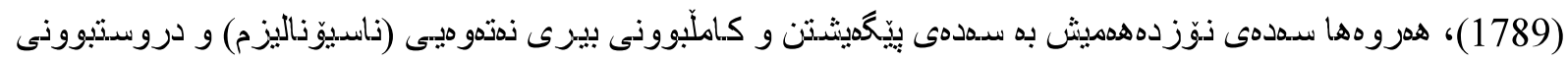

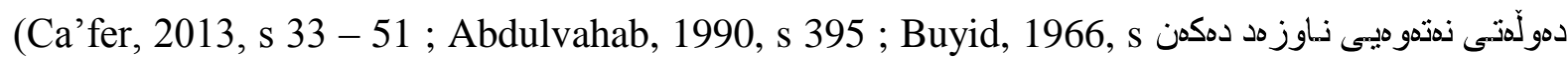

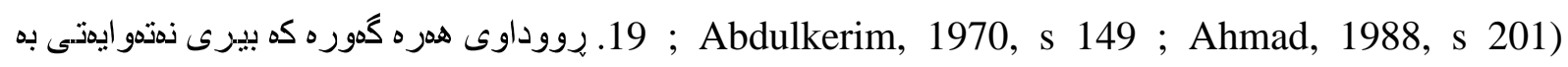

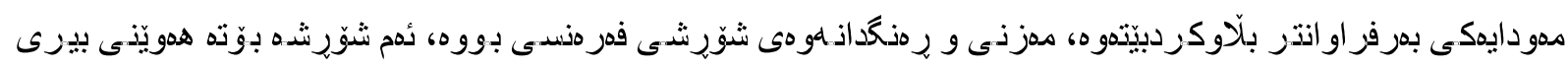

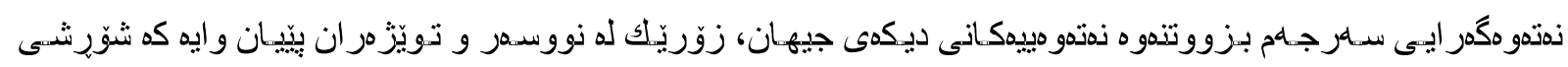

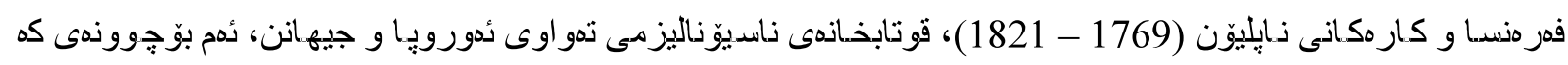

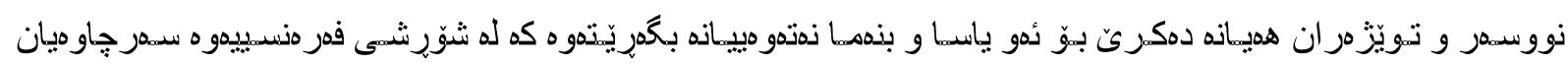

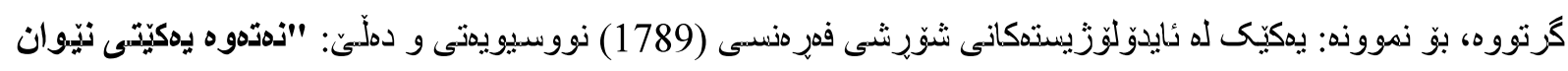

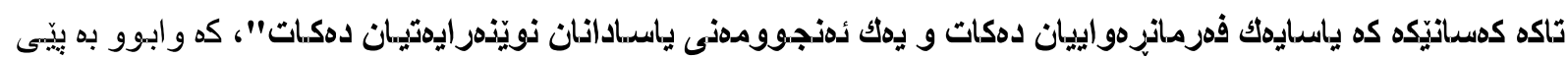

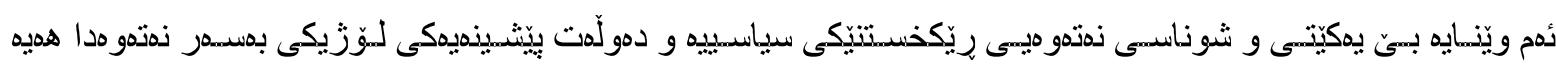
دوك تو (Komalek Nusar, 2017, s 6)

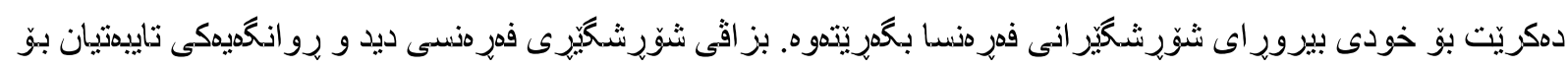

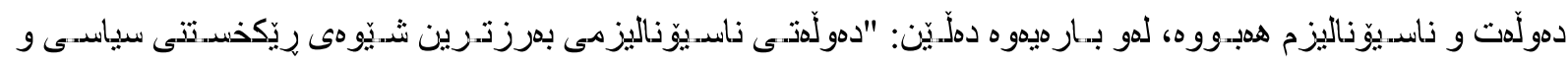

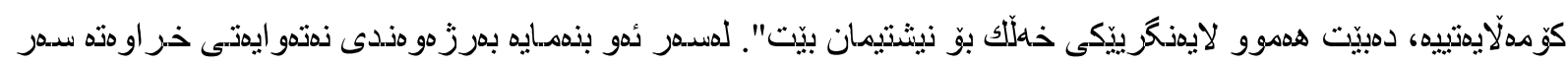

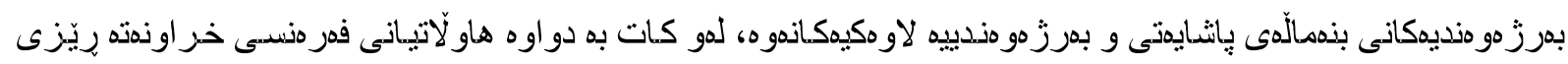

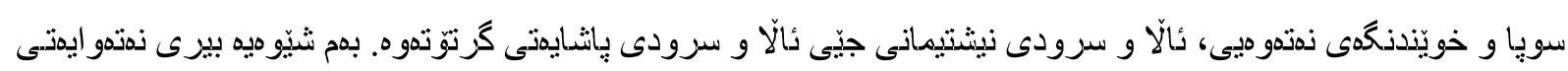

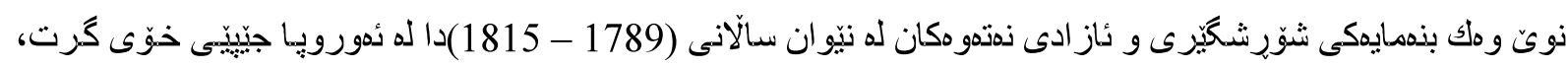

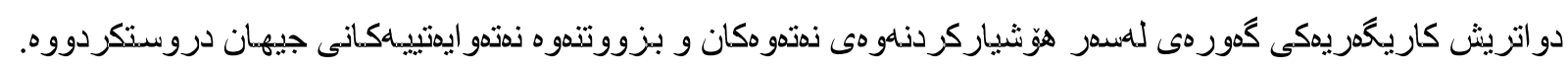

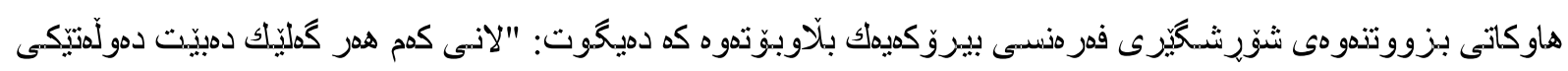

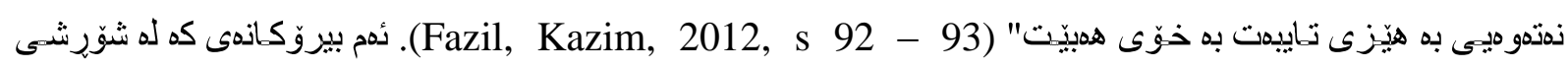

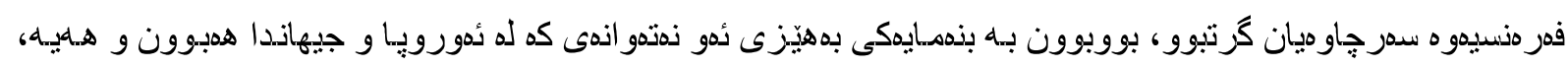

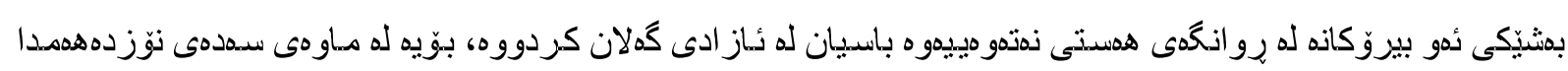

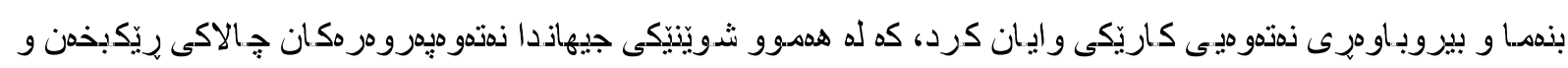

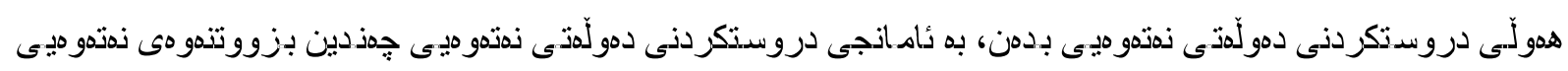

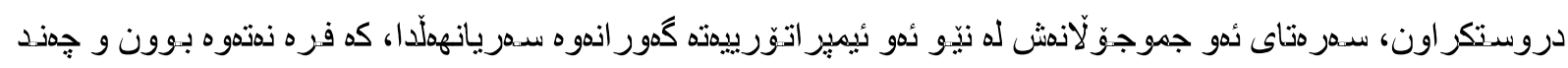

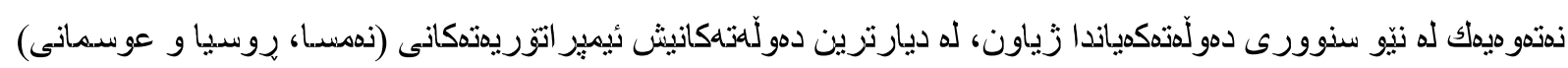
بوون (Nuradin, 1967, s 27)

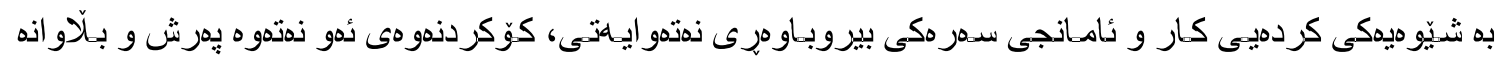

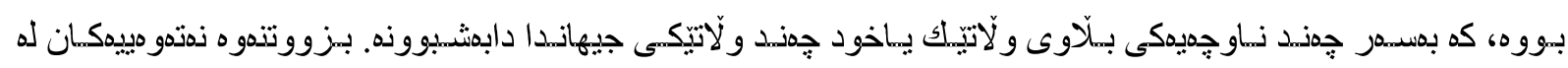

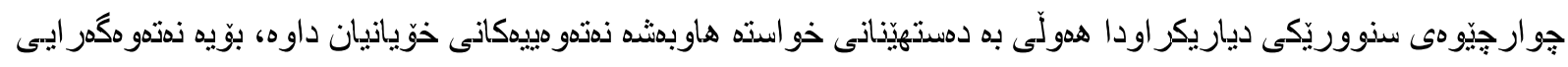

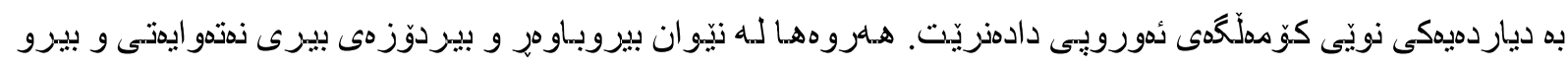

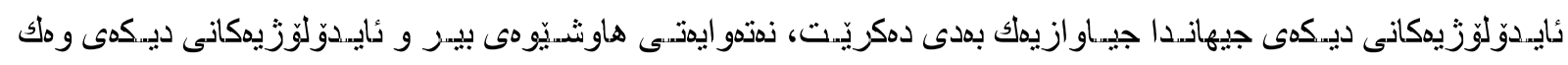

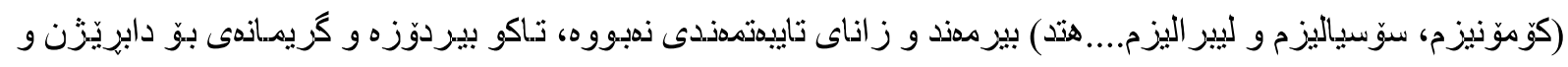

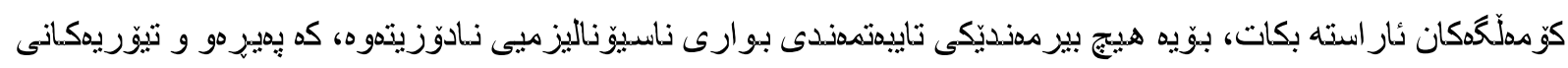




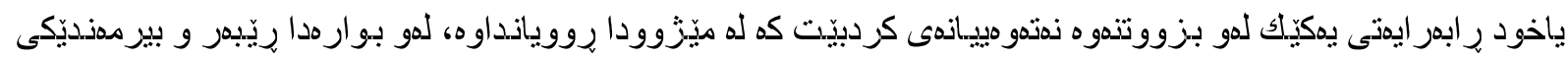

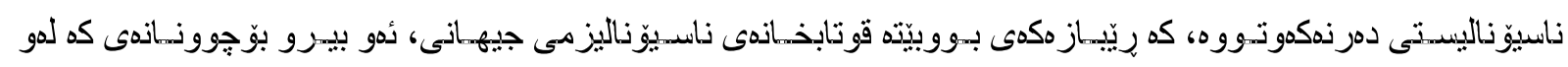

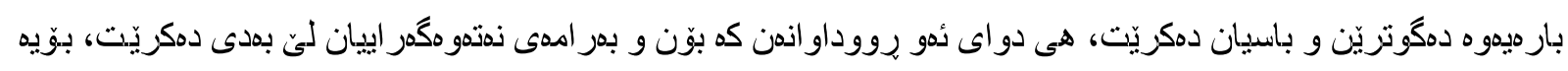

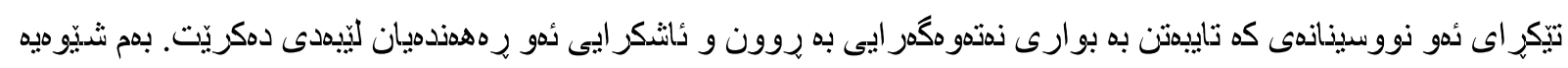

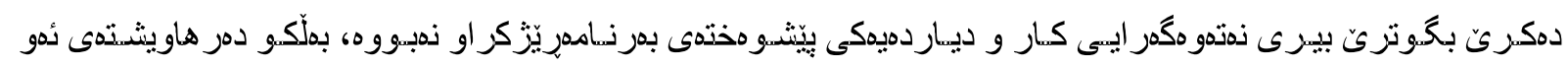

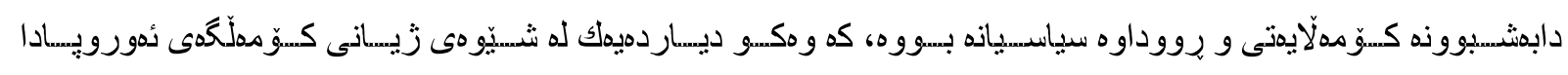

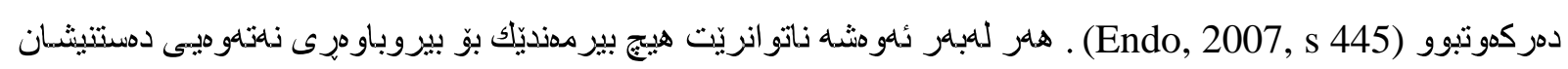

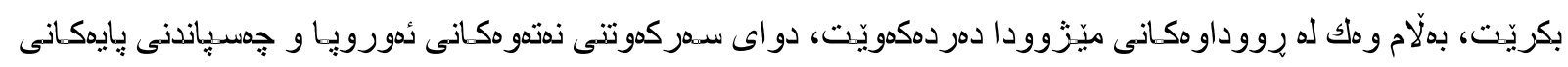

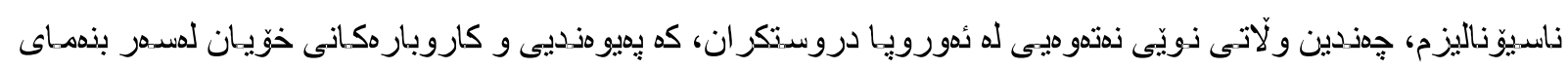

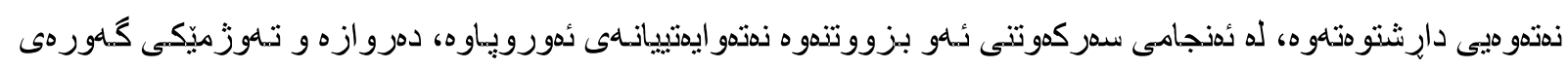

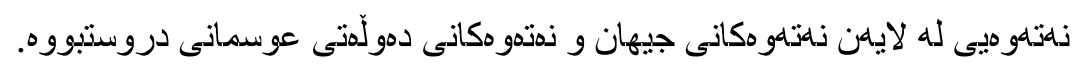

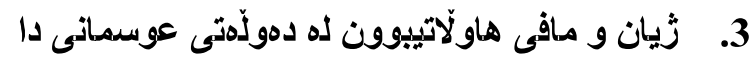

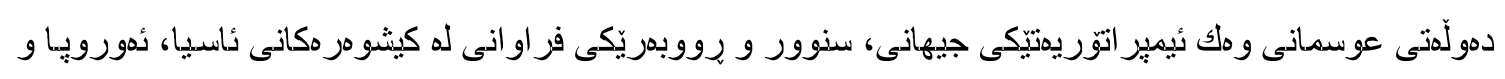

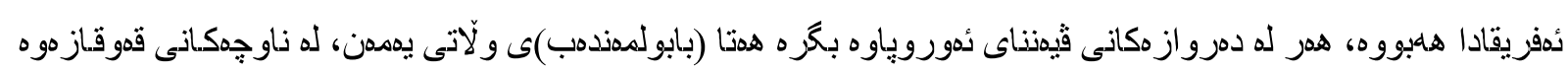

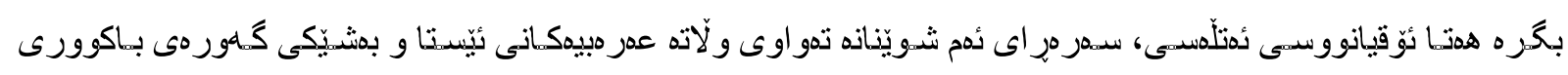

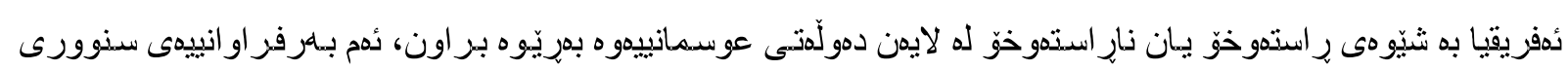

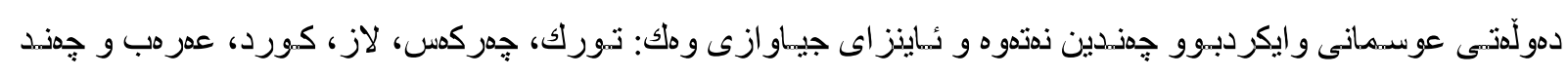

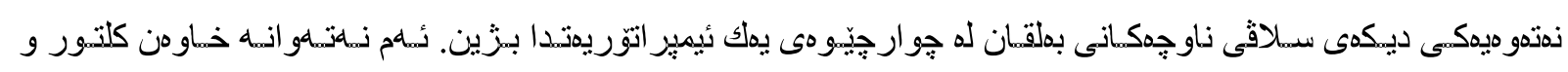

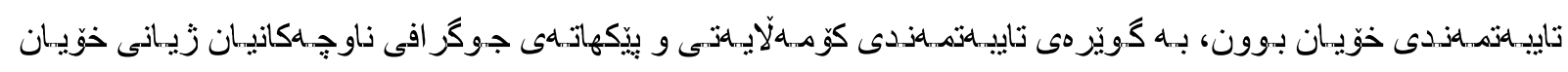

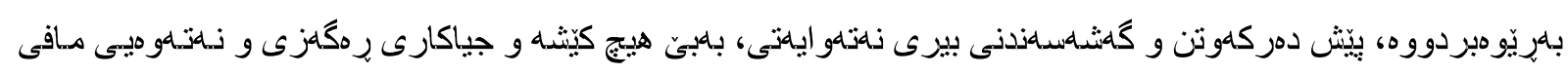

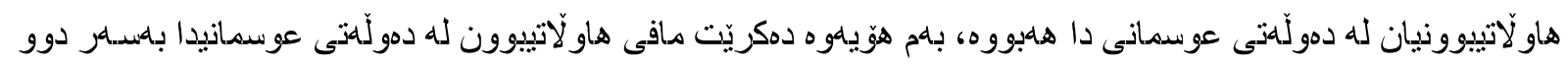

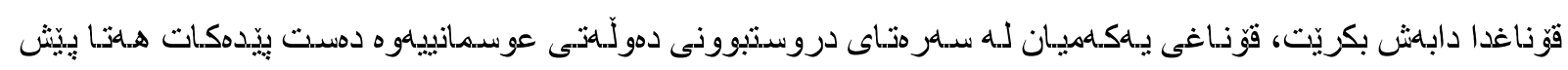

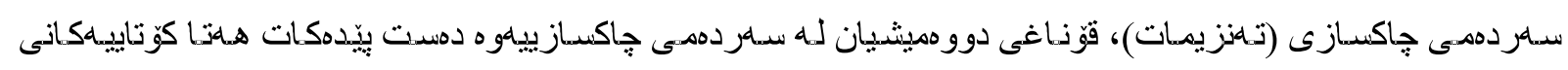

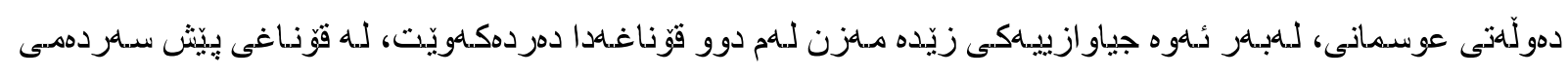

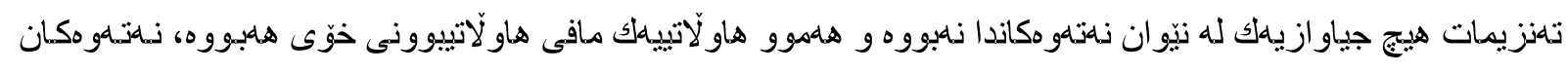

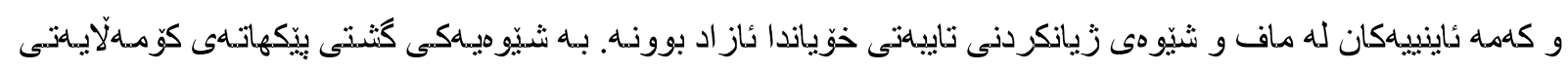

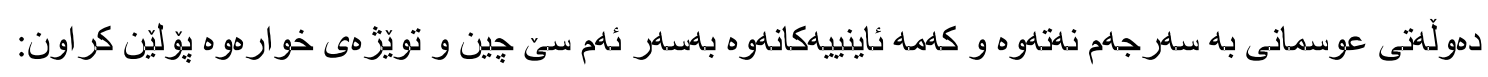

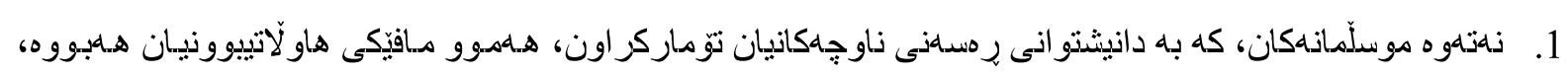

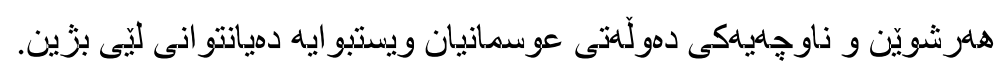

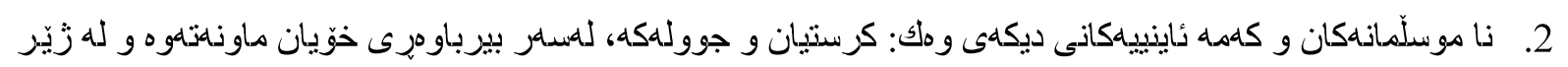

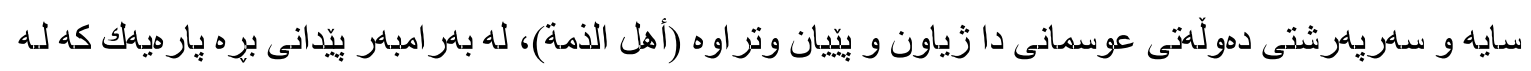




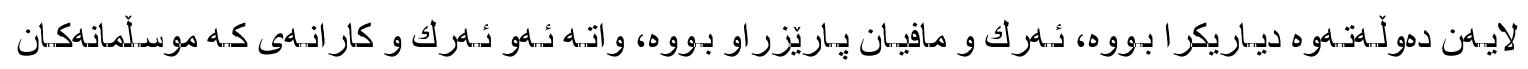

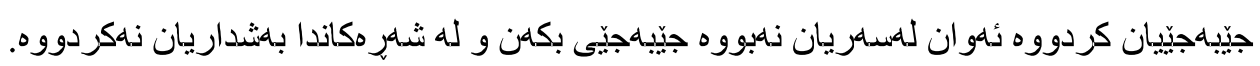

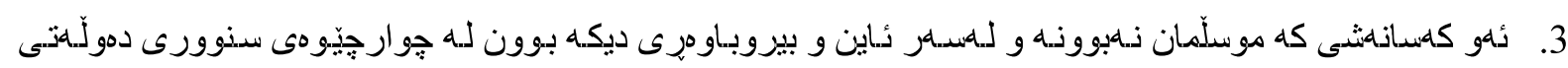

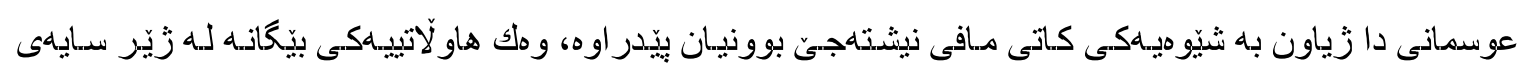
دهولّهندا ماف و زيانيان باريّزراوه.

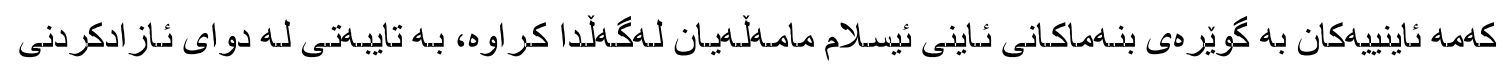

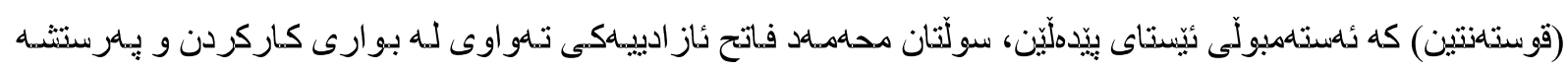

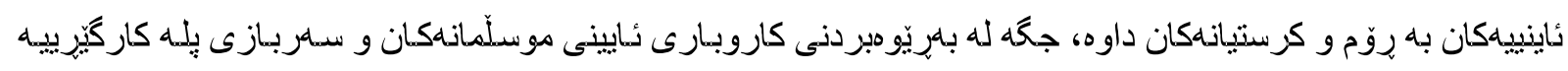

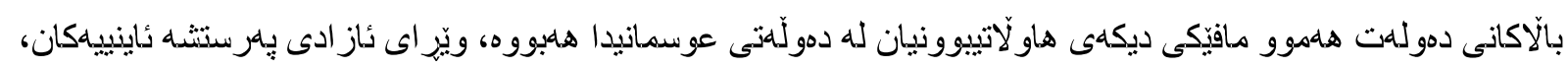

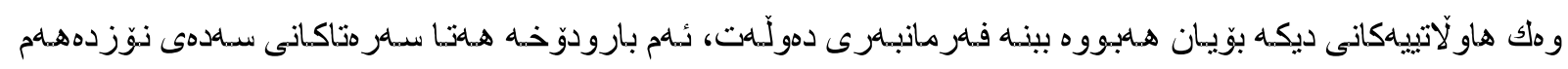

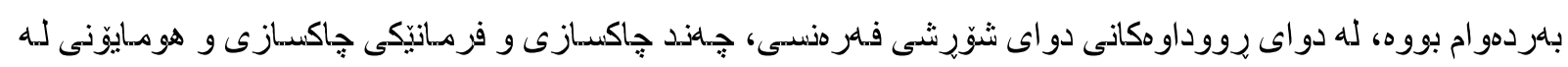

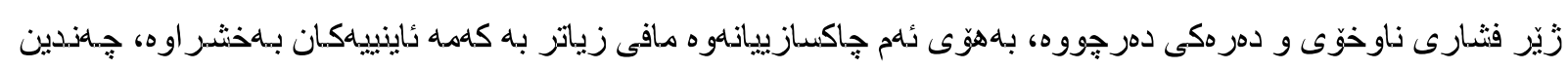

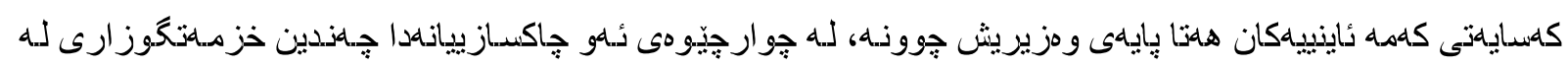

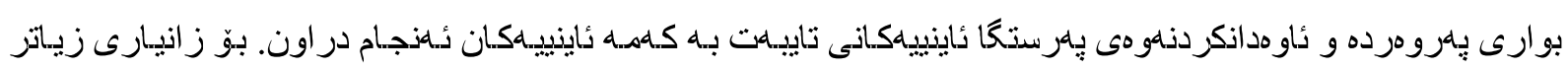

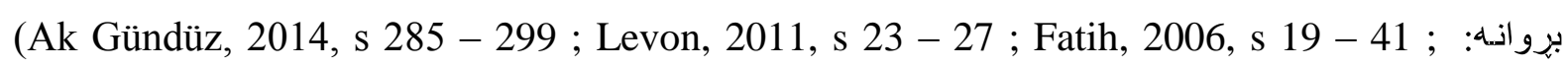
.Güler, 2003, s $9-29$ )

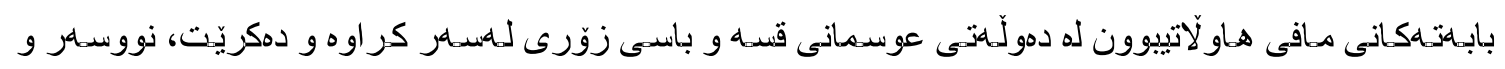

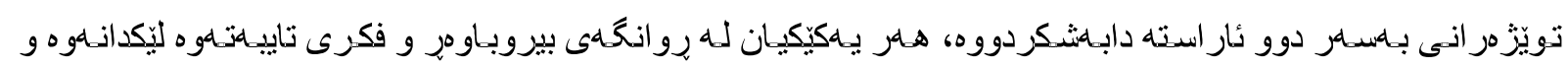

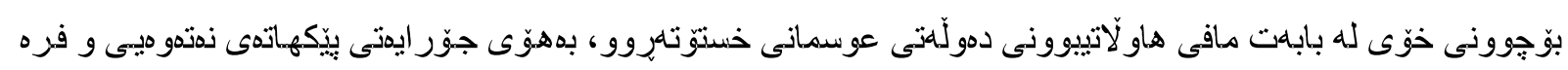

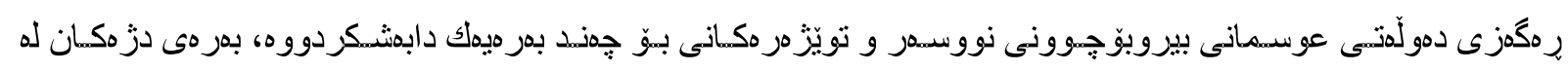

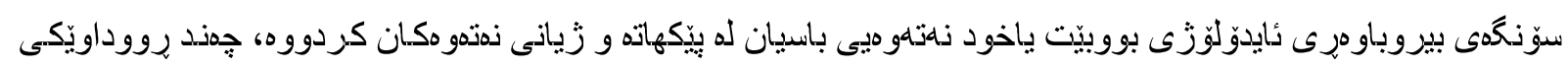

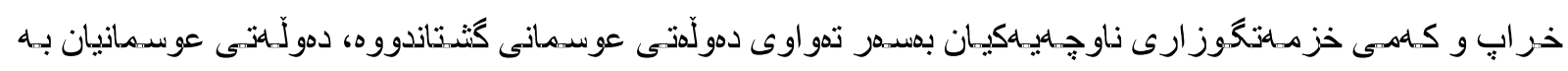

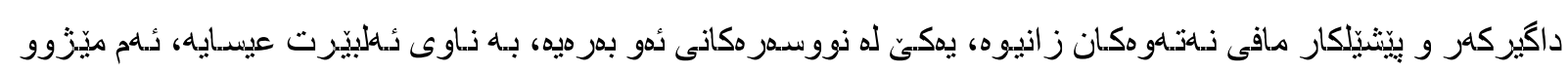

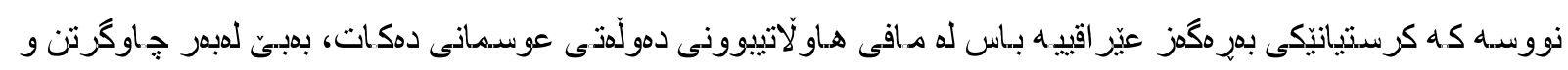

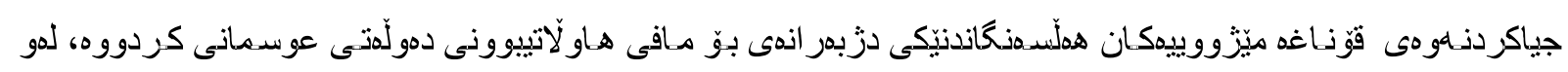

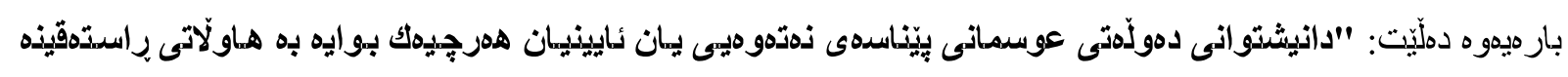

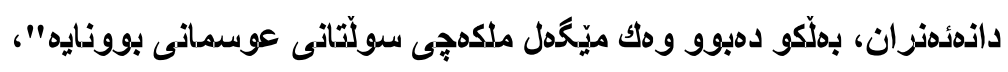

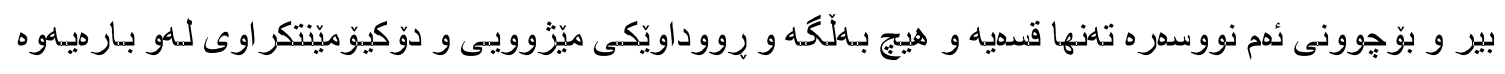

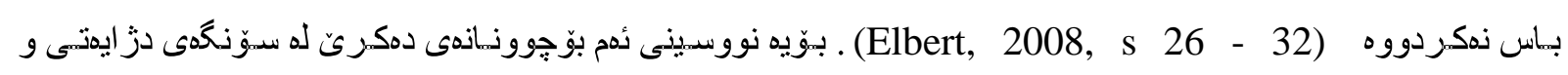

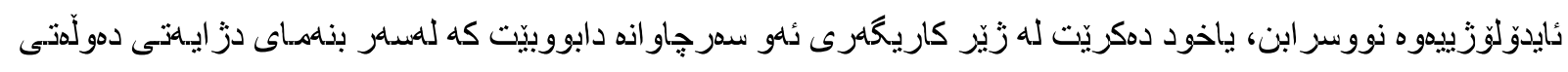

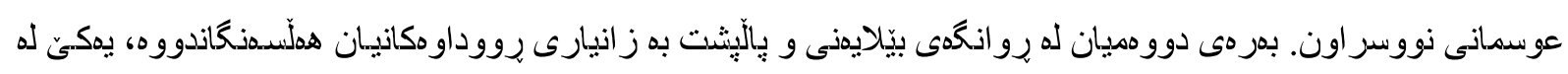

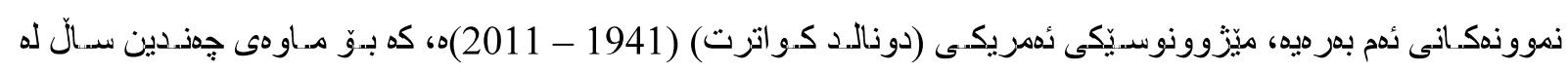

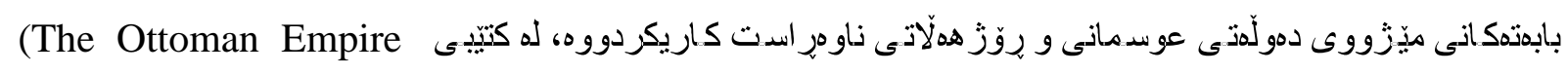

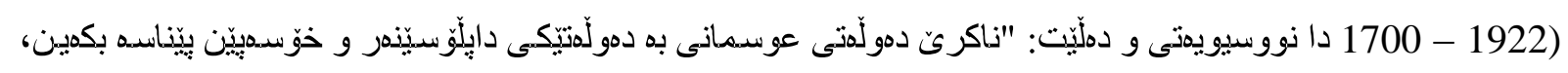




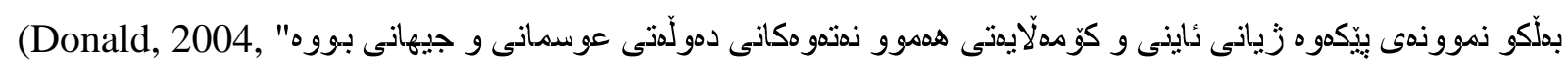

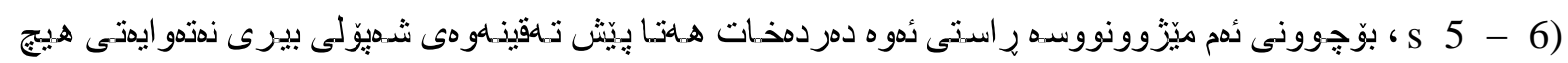

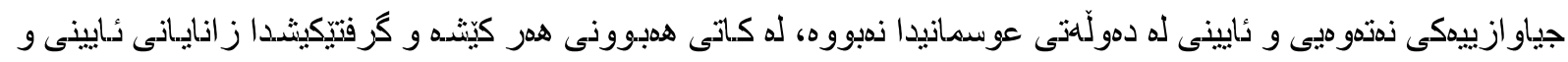

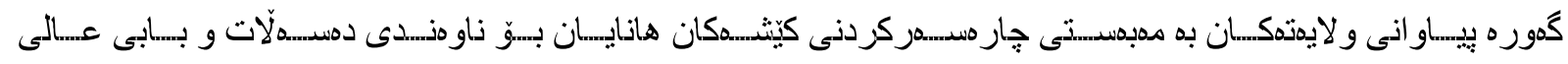

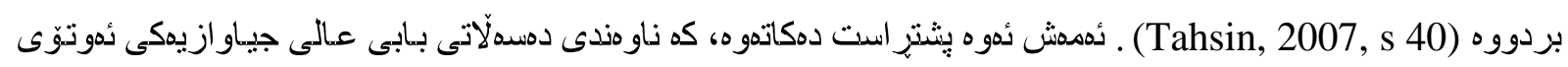

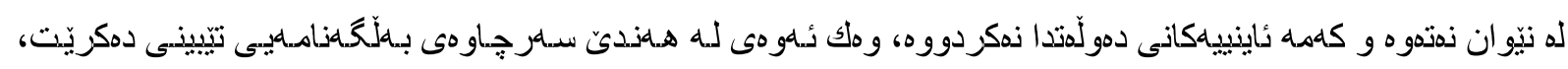

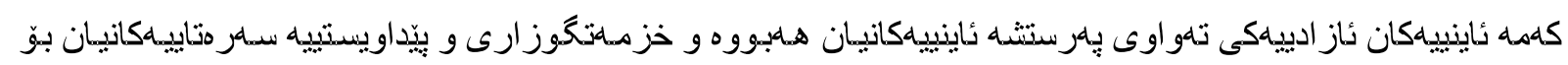
دابينكر اوه (Levon, 2011, s 23 - 28).

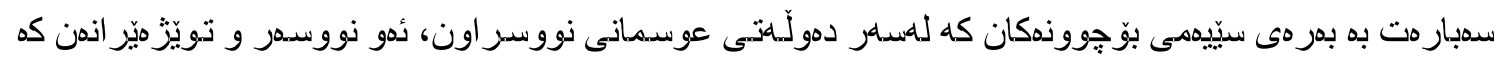

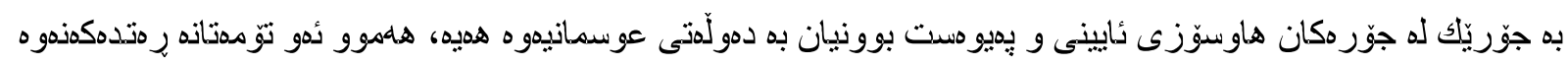

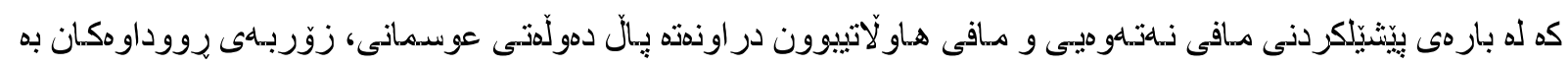

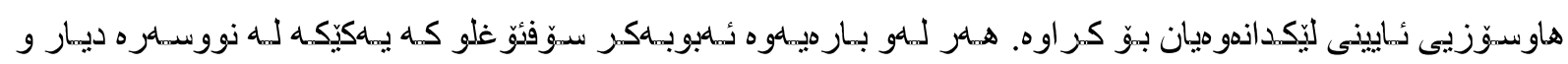

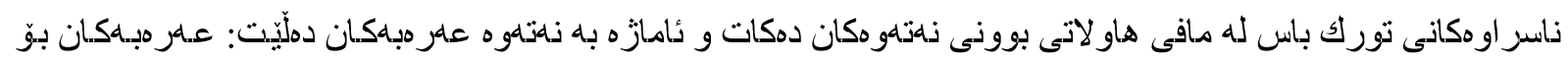

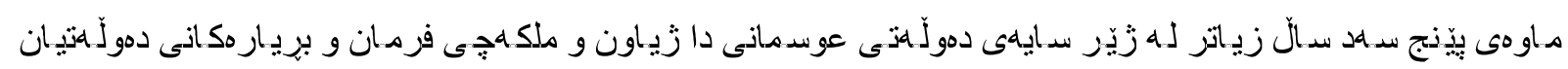

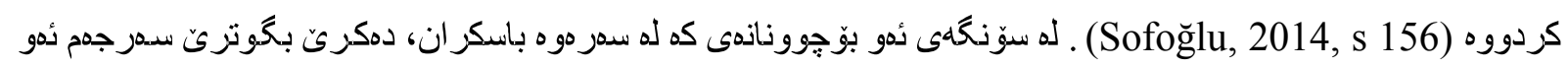

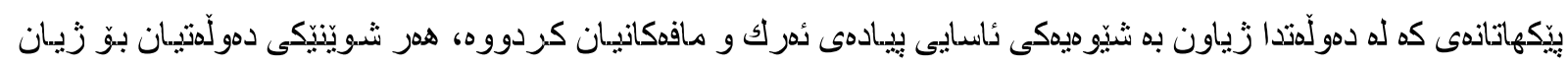

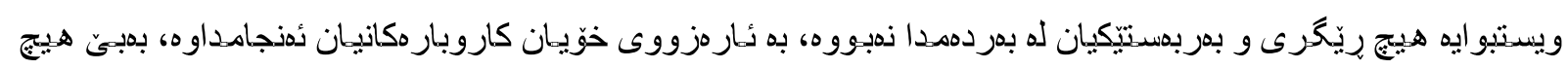

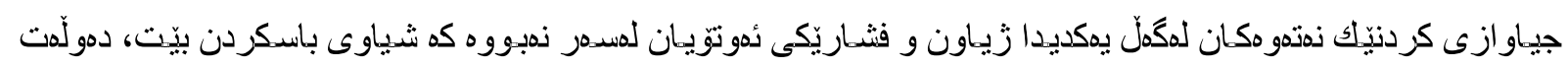

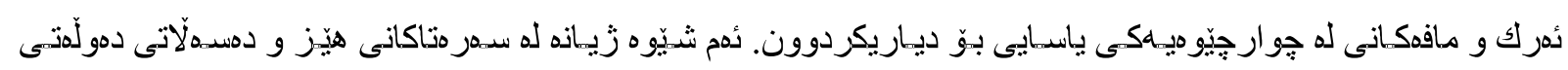

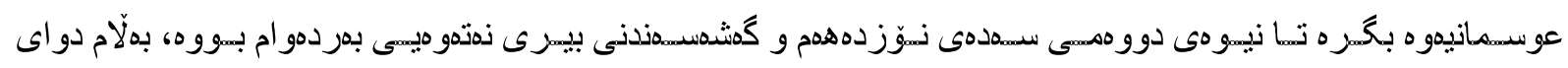

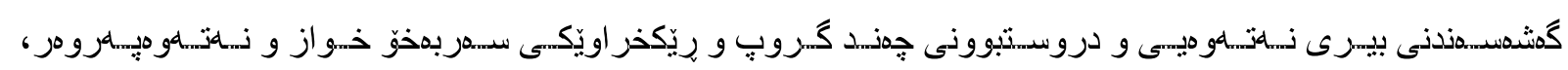

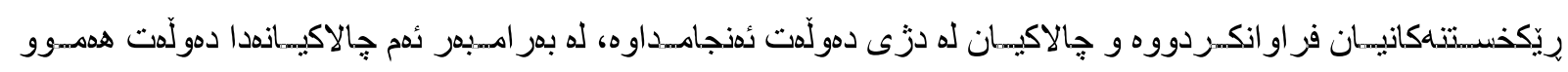

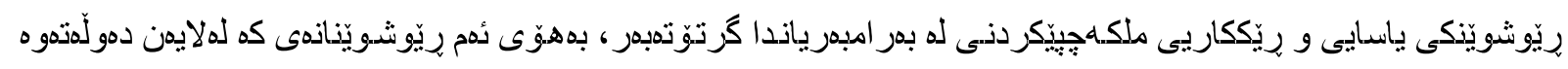

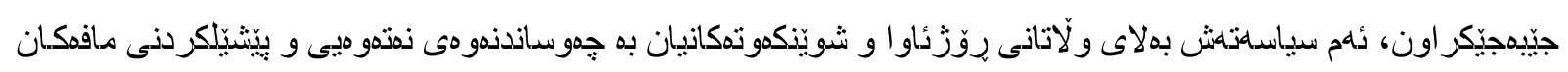
له سهرجهاو هكاندا باسكر اون.

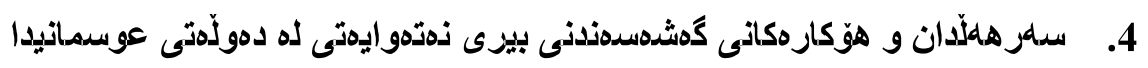

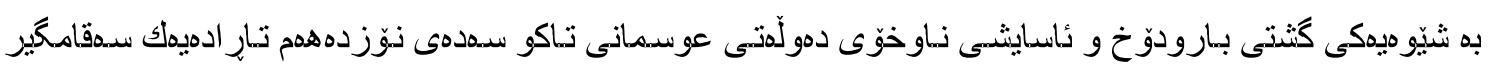

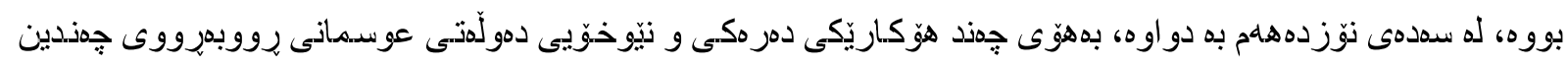

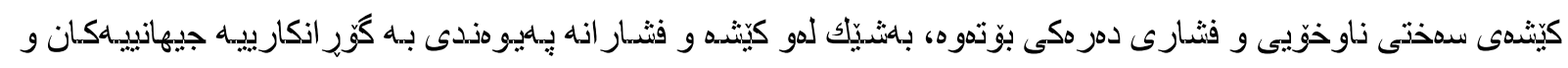

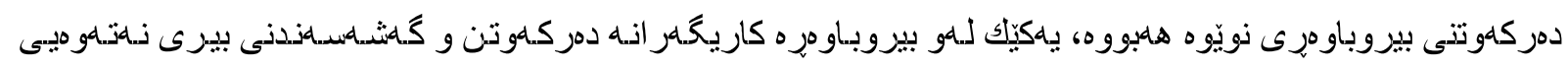

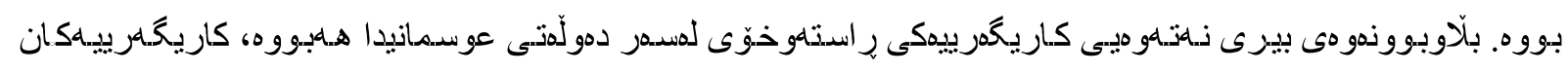

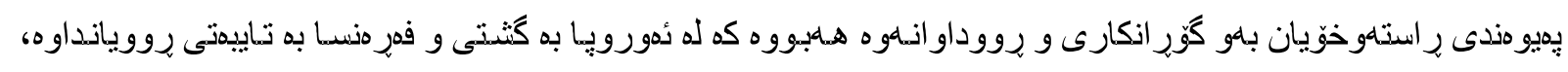




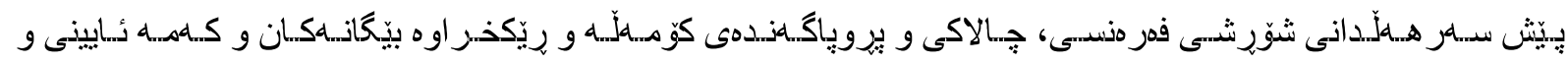

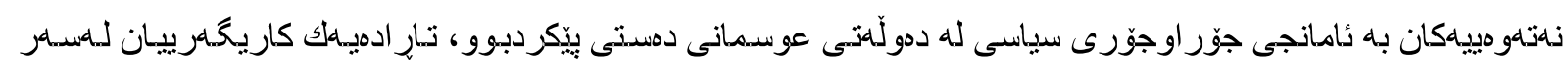

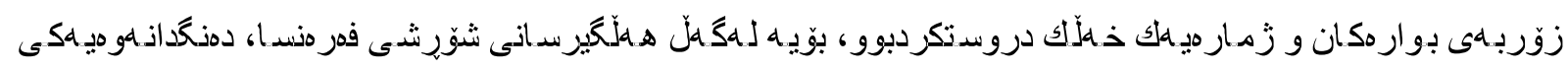

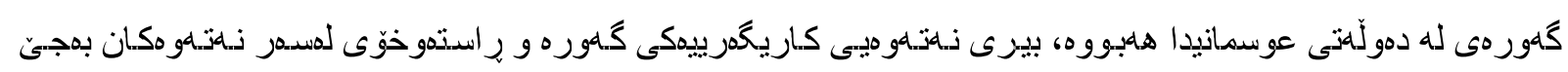

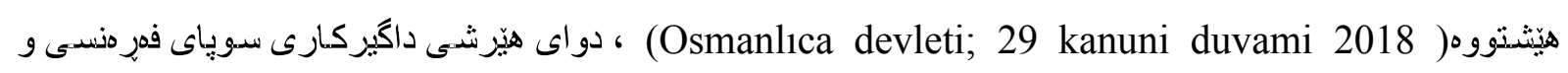

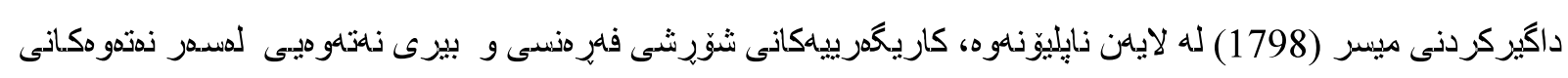

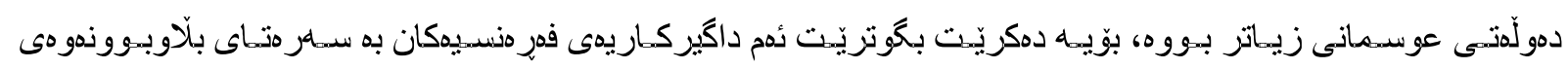

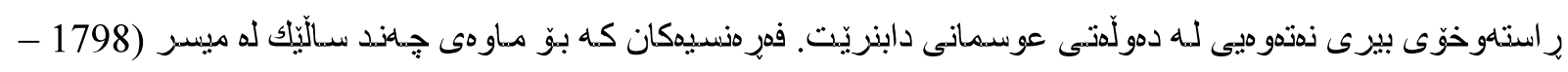

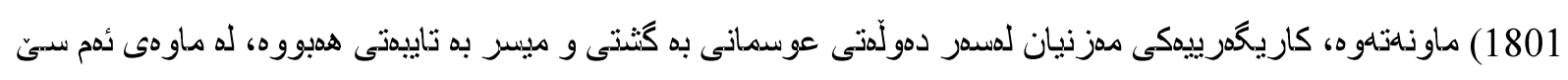

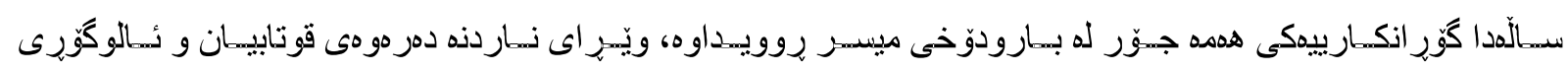

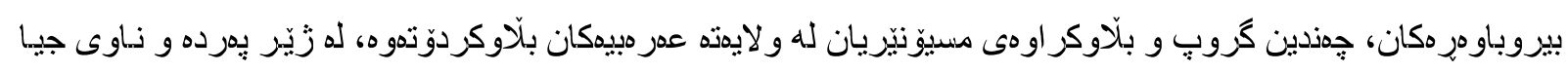

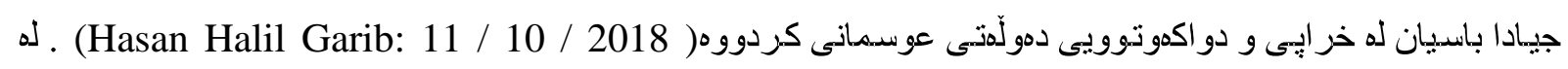

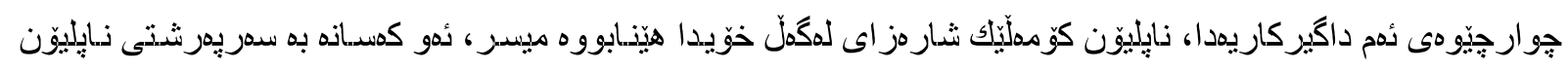

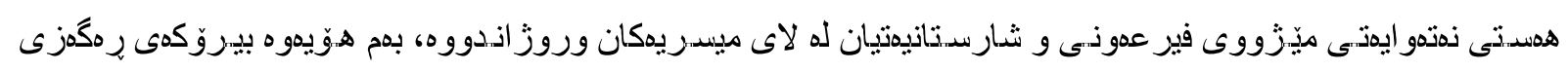

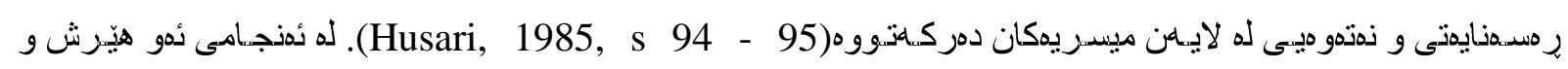

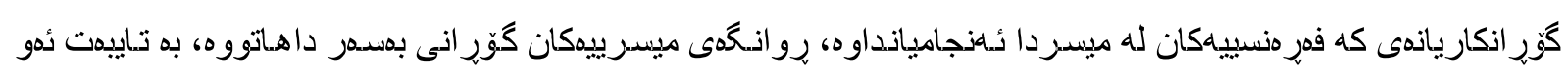

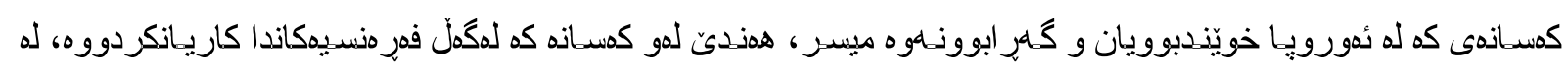

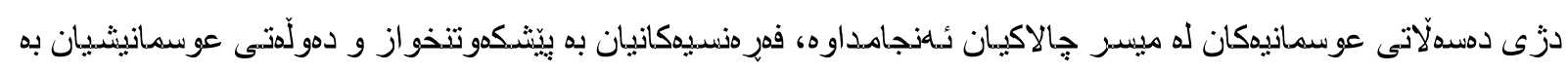

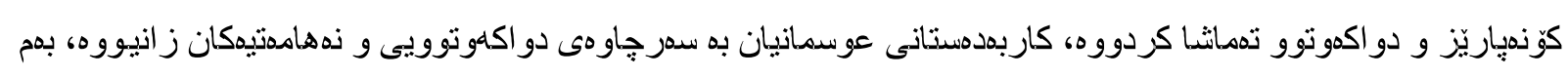

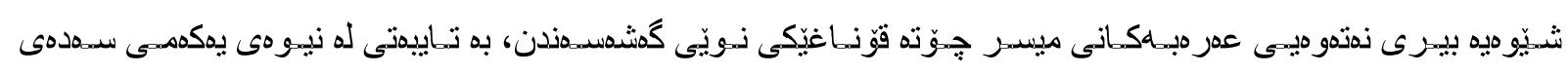

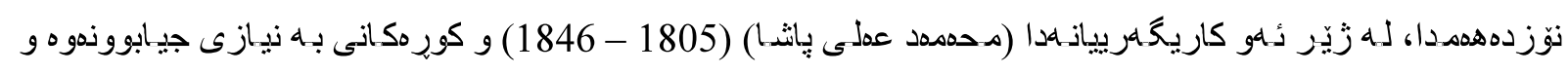

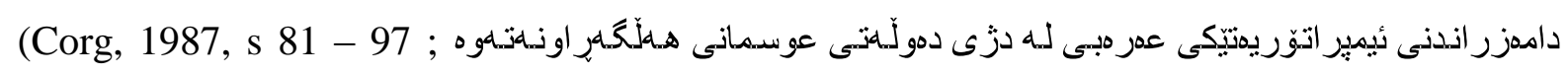

.Ortayl1, 2013, s 109)

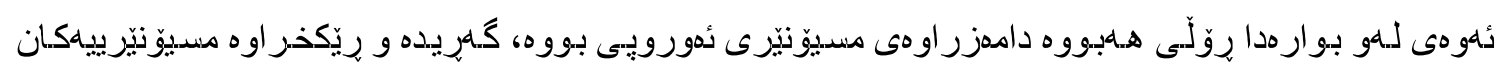

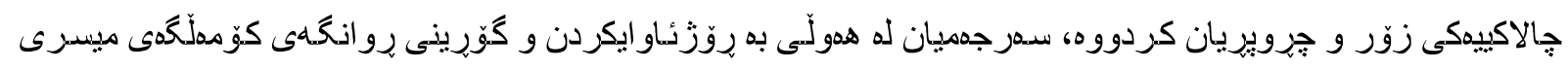

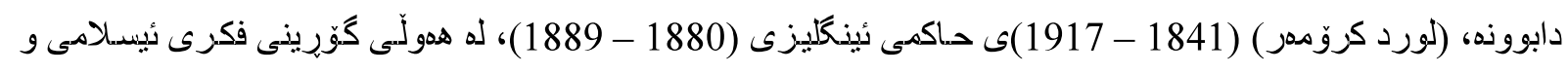

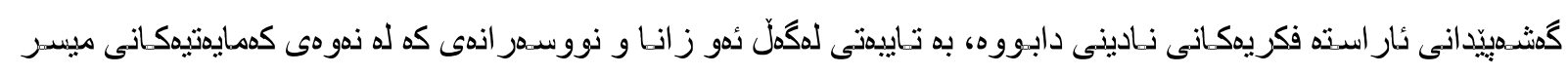

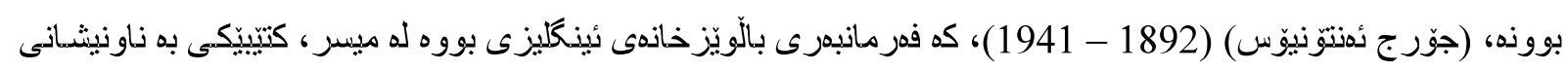

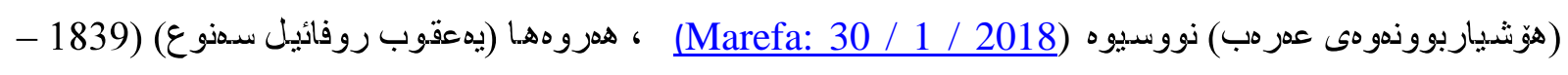

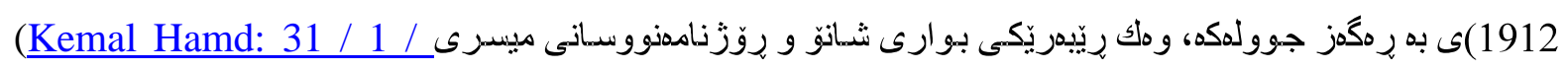

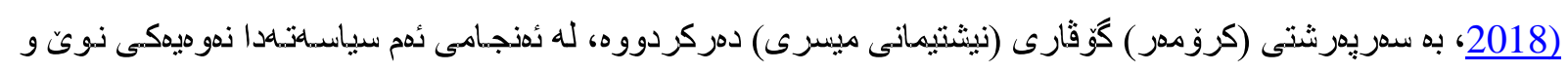

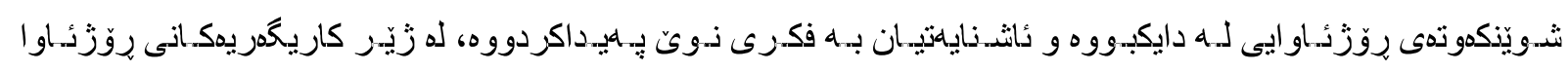

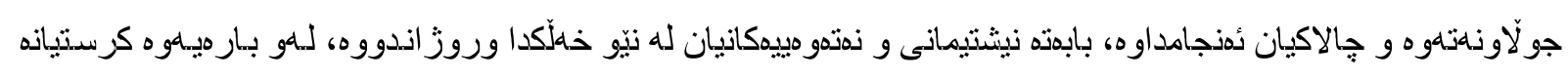

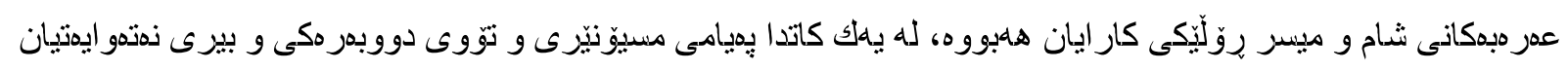




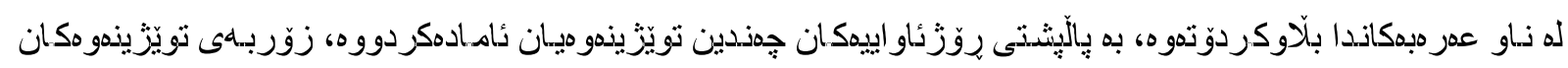

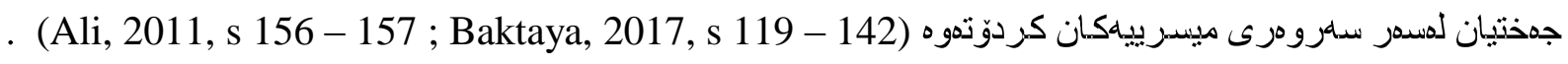

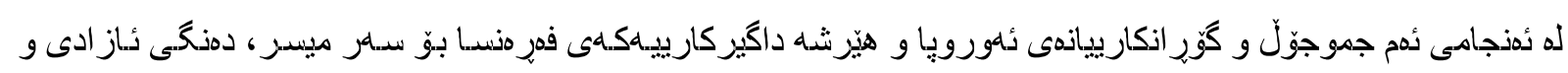

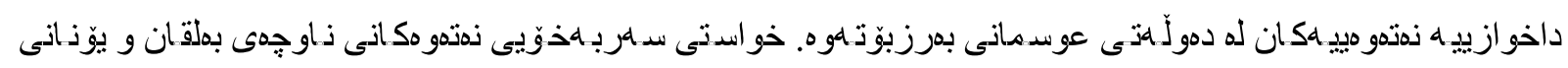

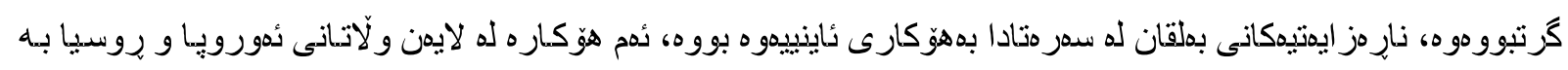

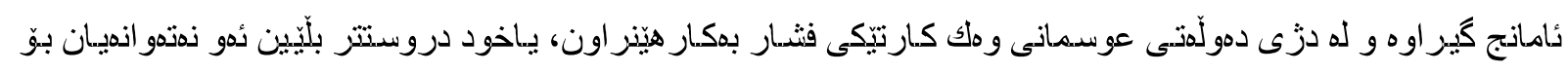

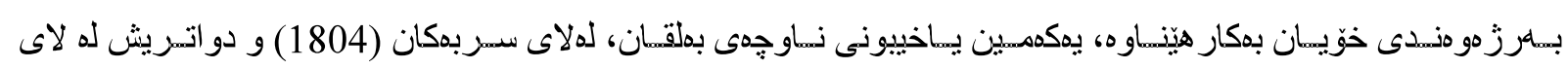

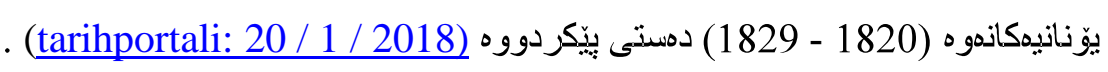

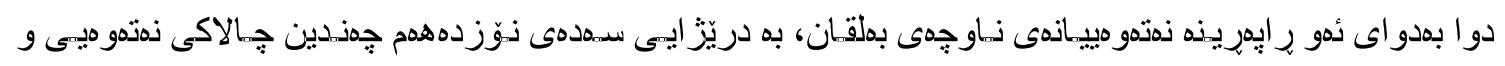

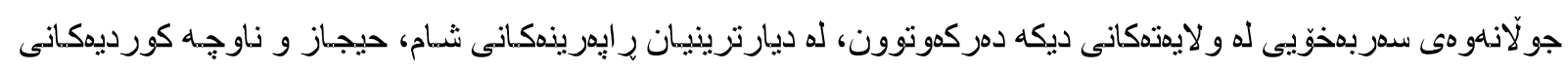

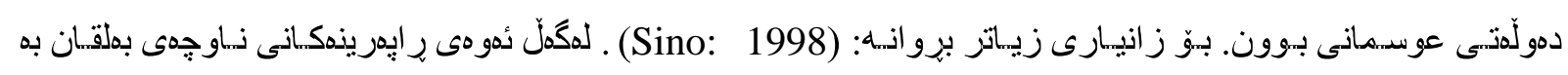

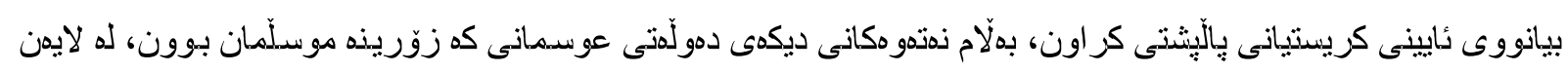

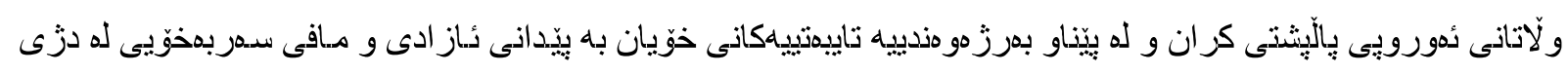

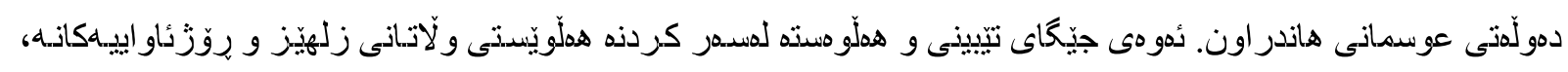

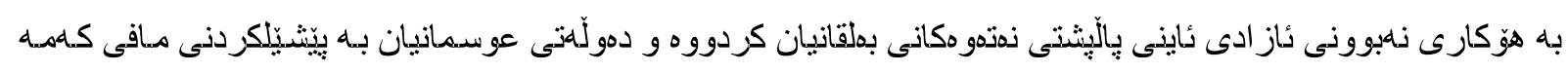

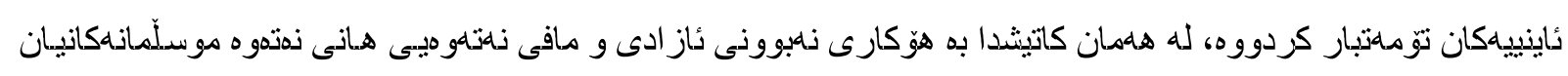

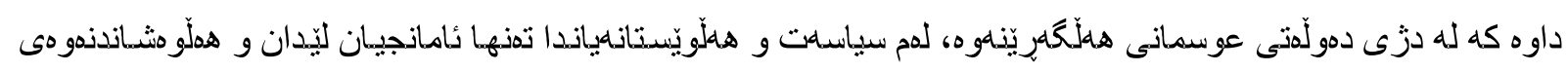

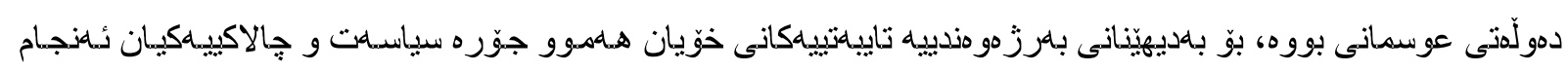

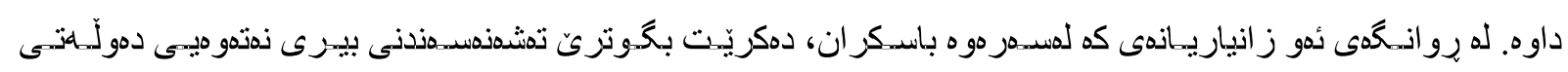

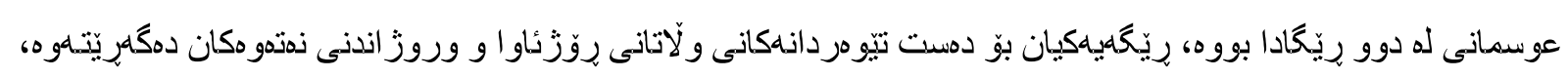

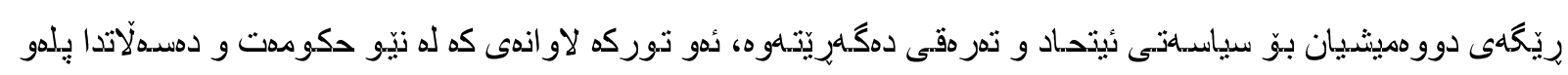

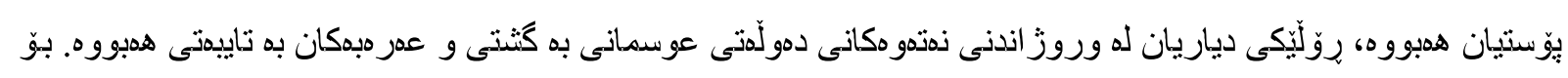

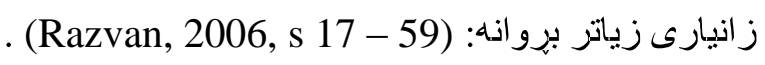

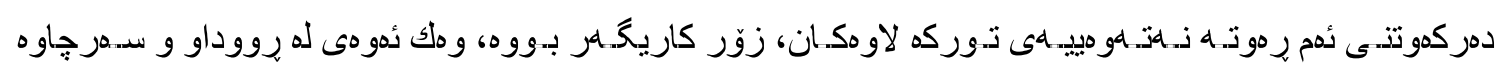

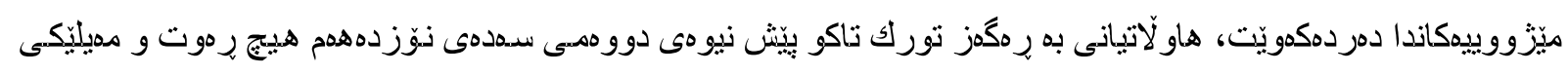

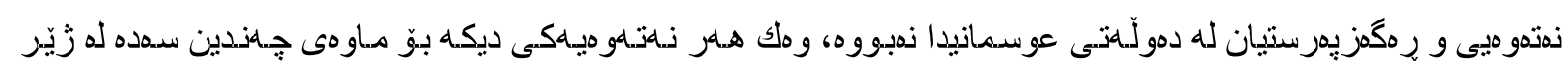

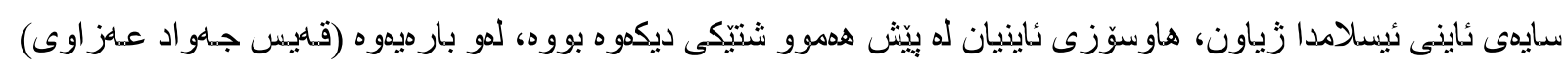

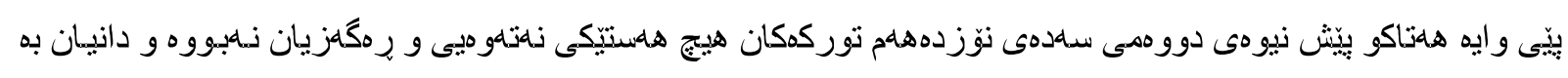

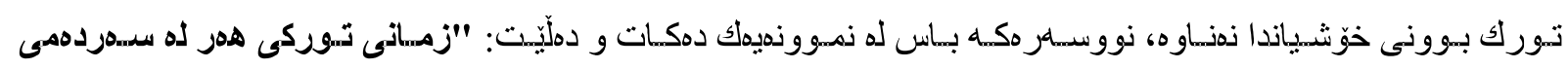

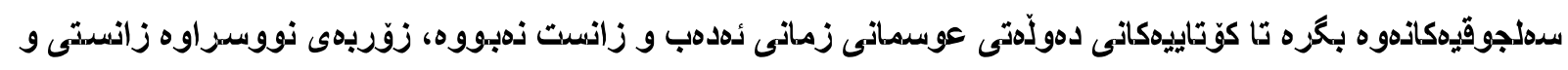

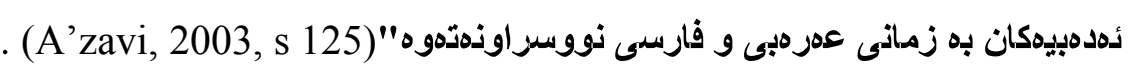

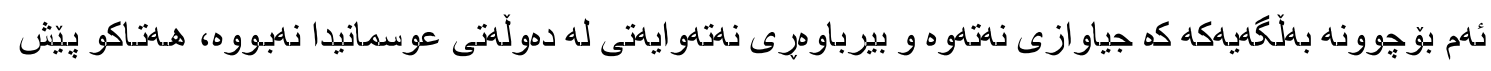

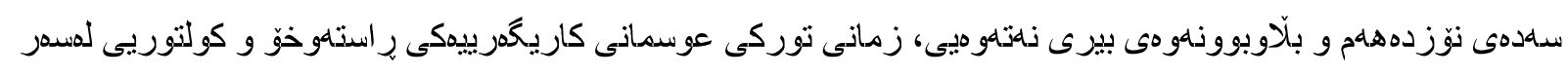

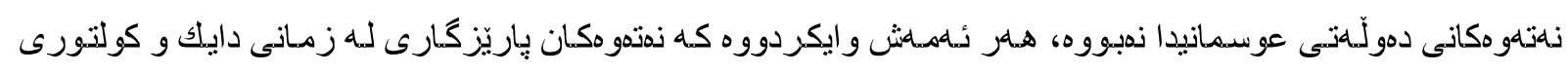




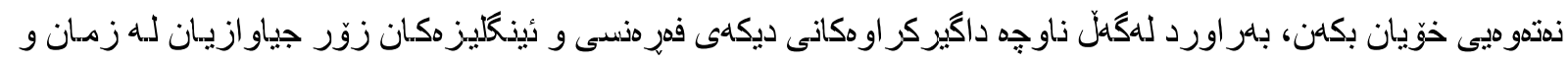

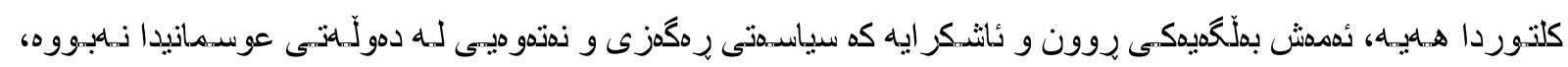

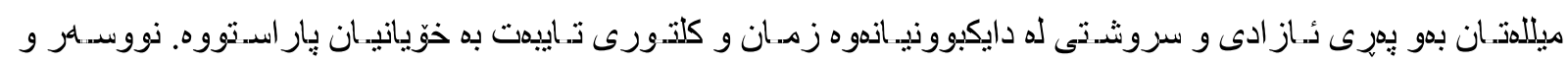

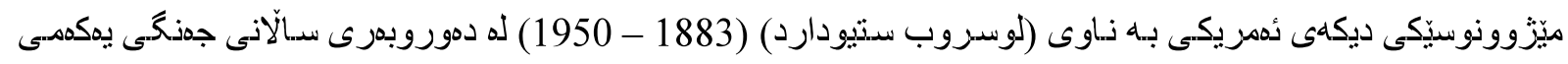

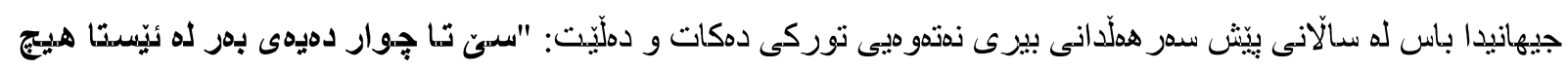

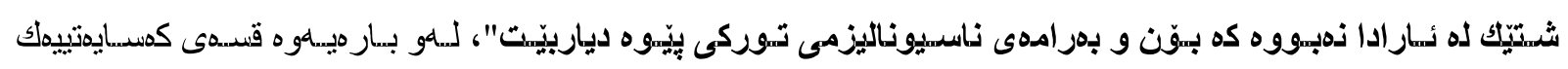

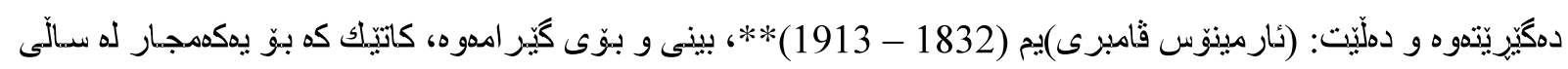

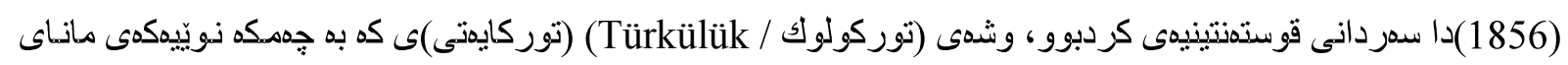

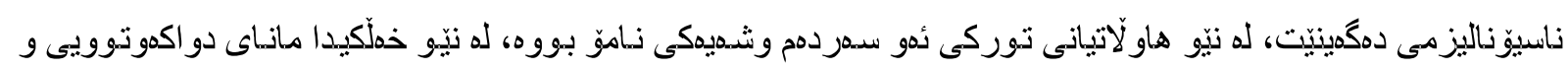

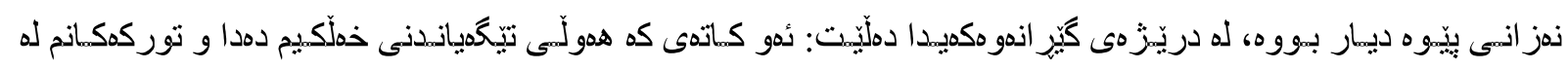

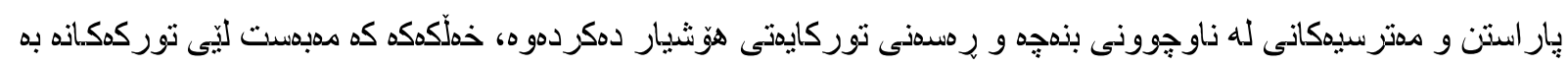

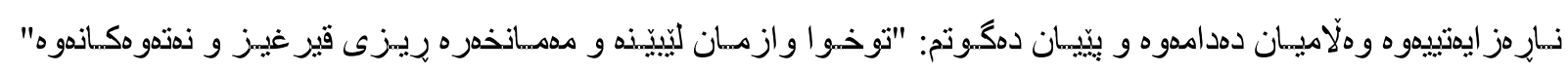

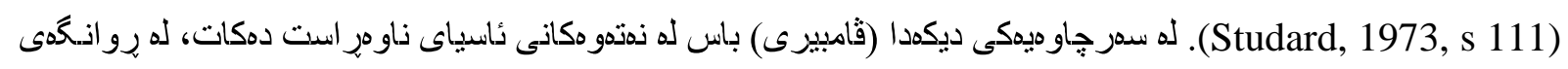

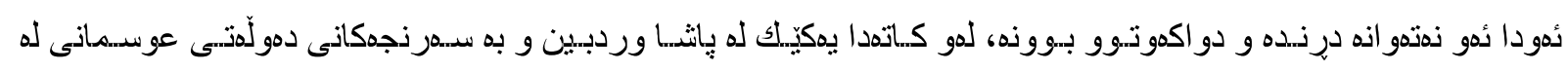

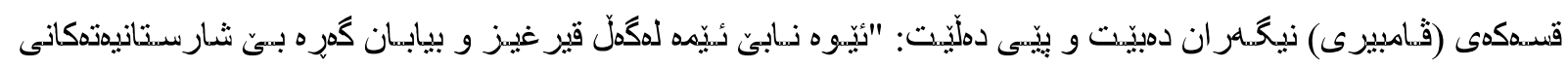

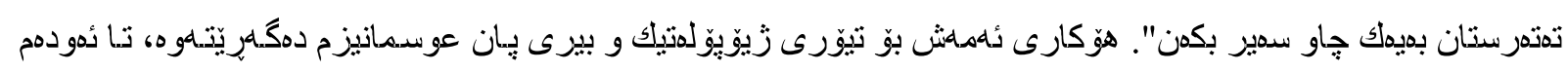

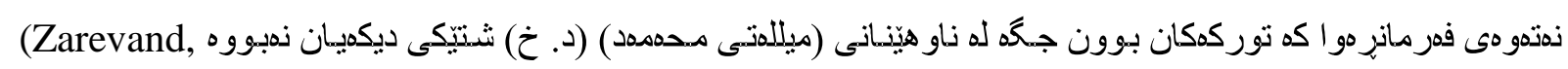

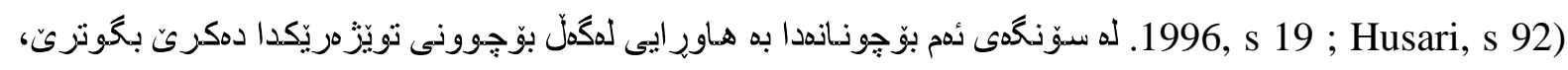

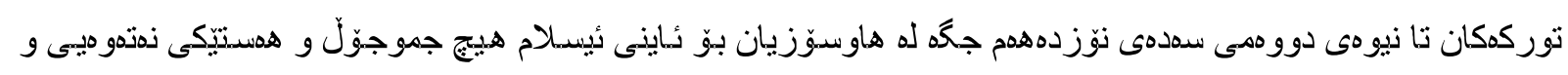

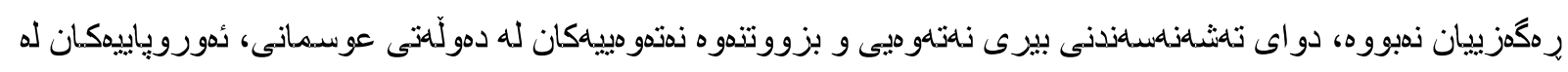

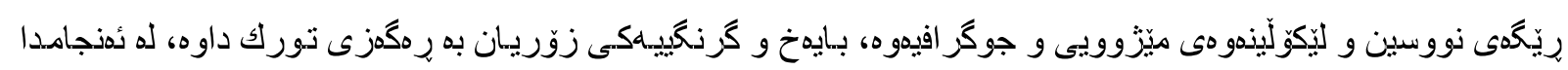

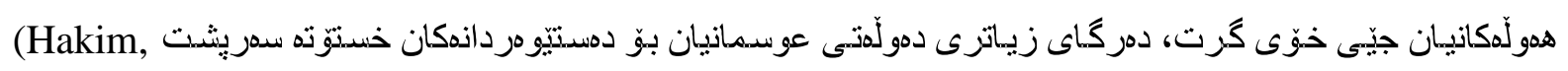

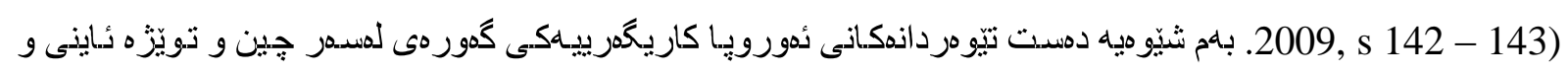

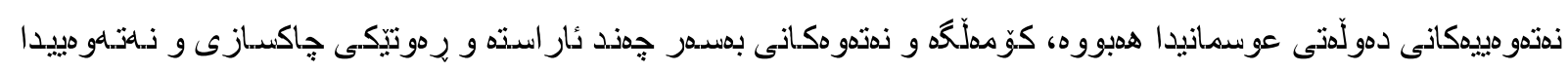

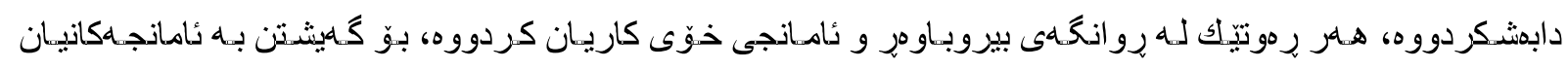

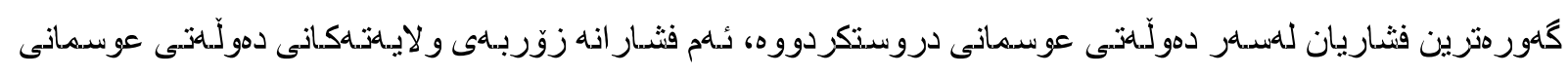

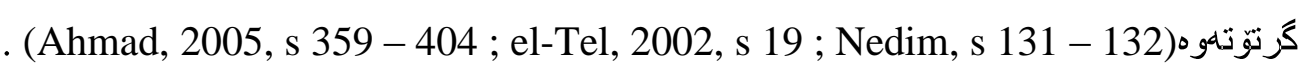

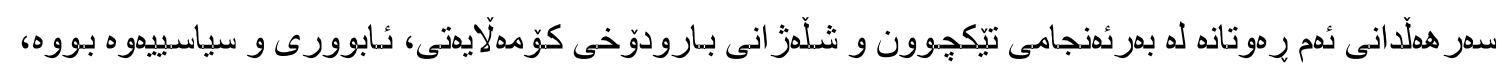

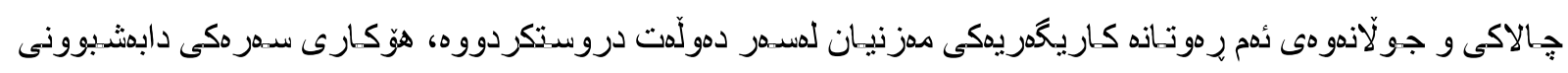

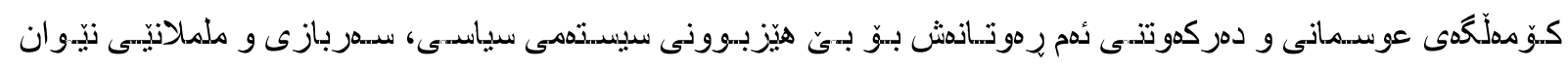

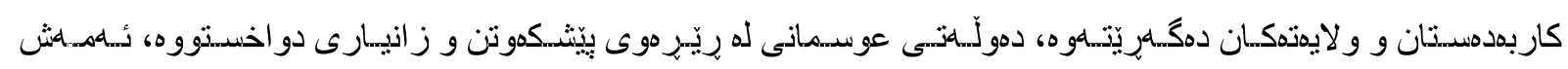

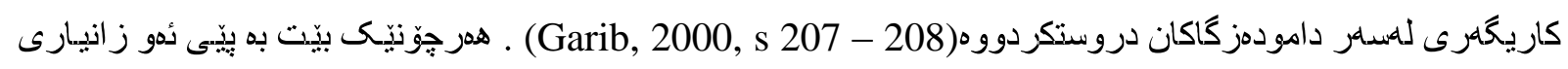

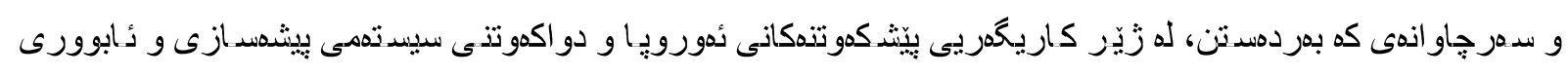

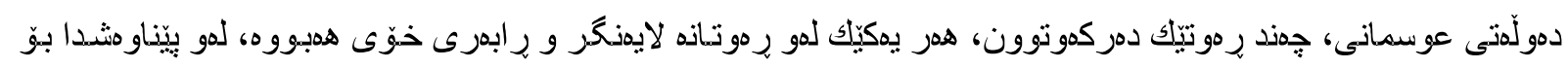




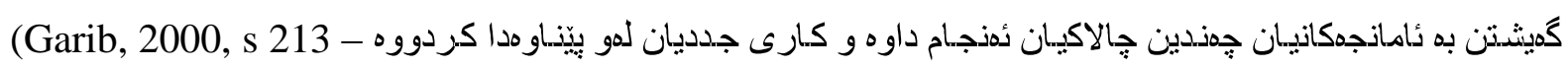

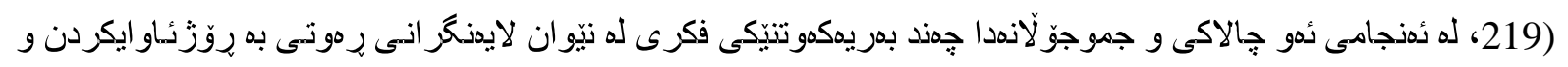

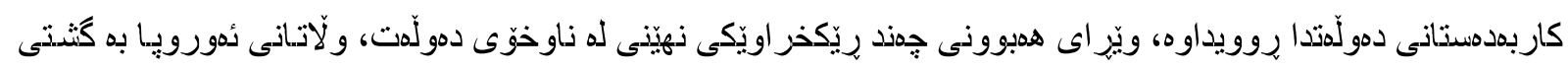

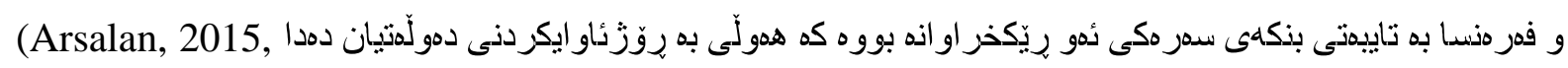
.s $34-35$ ve s $41-46)$

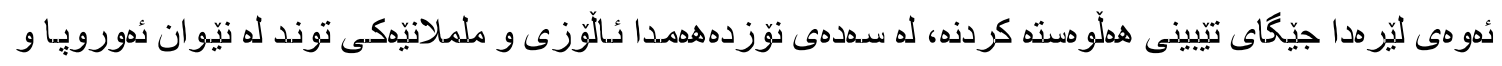

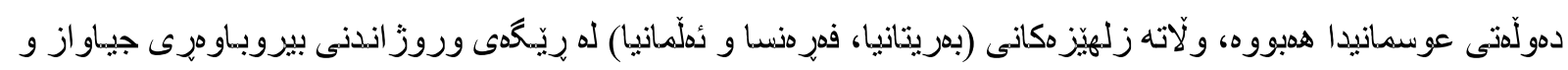

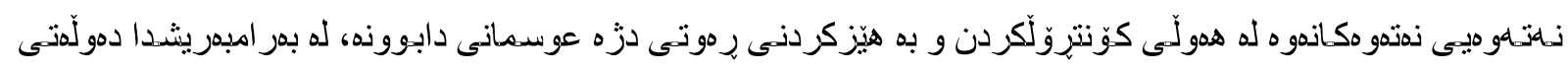

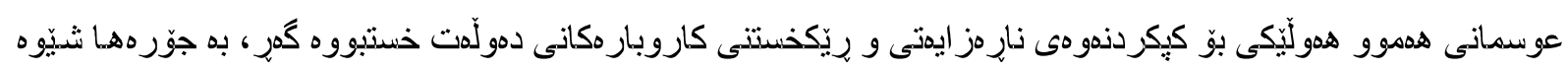

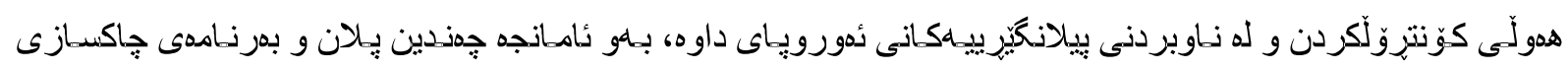

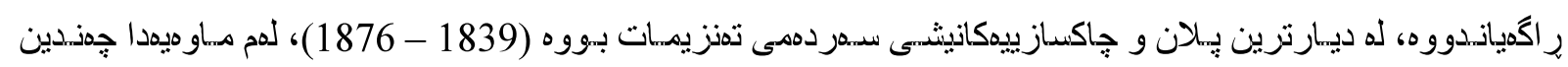

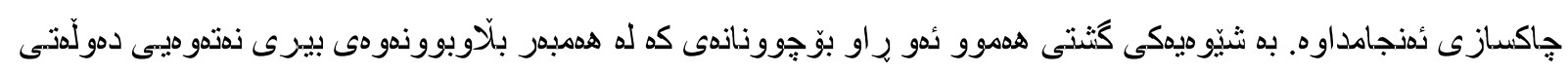

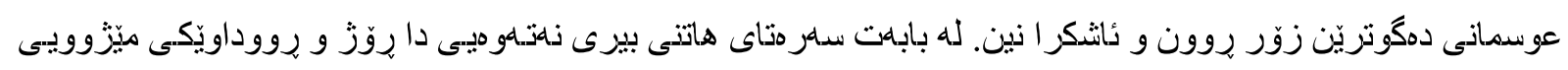

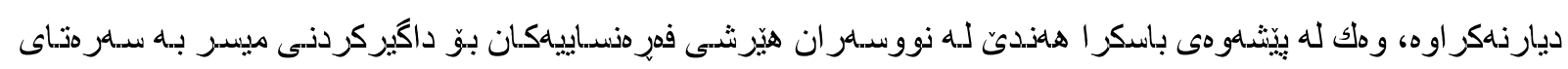

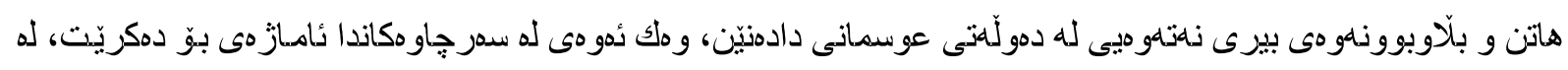

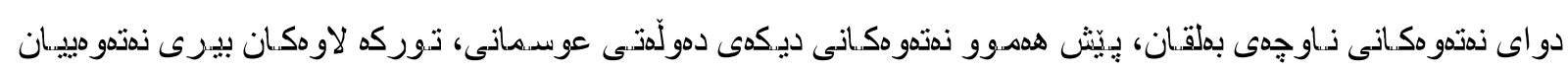

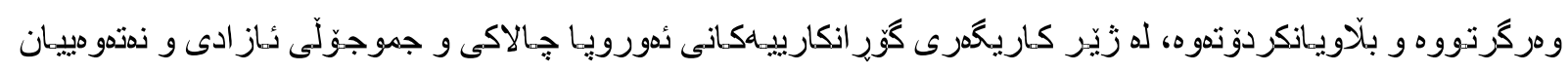

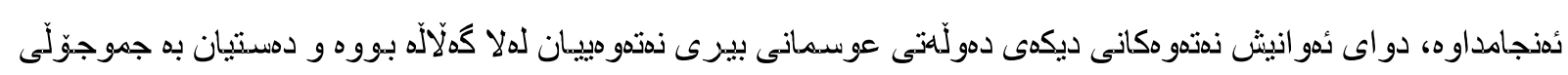

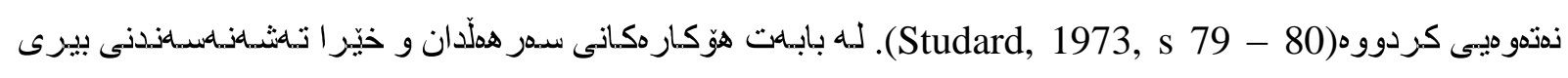

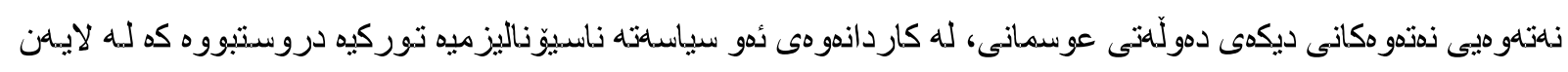

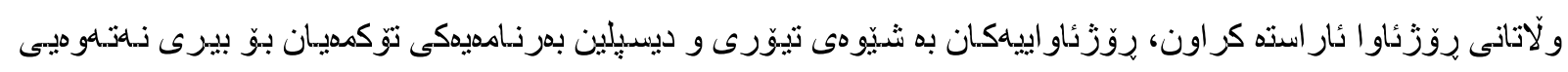

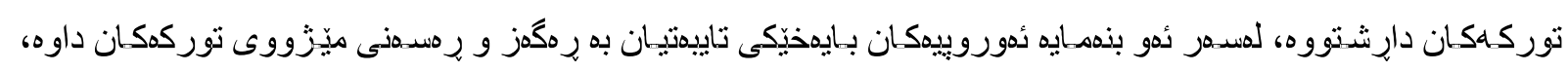

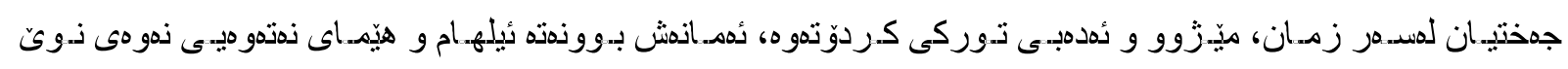

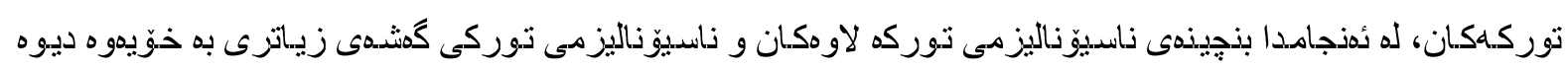

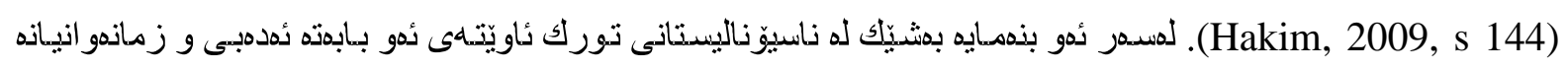

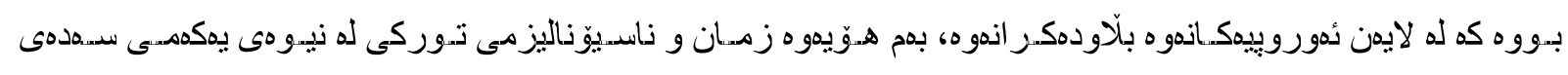

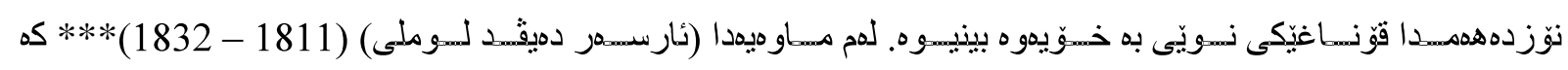

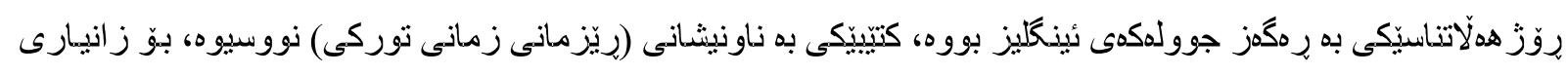

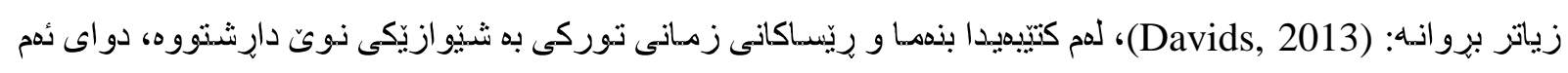

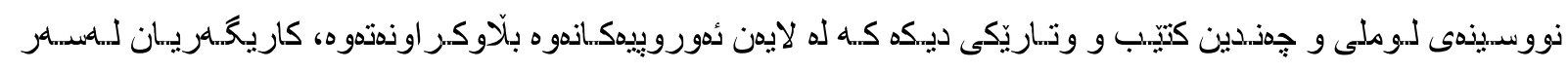

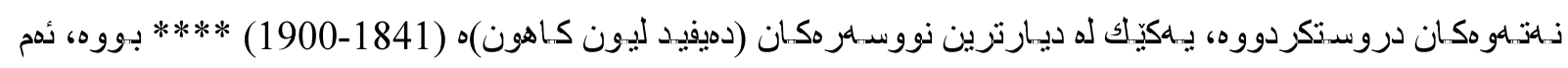

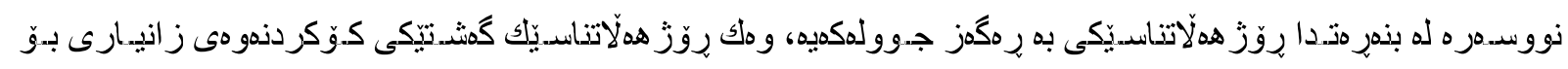

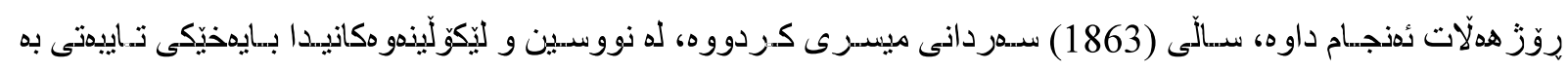

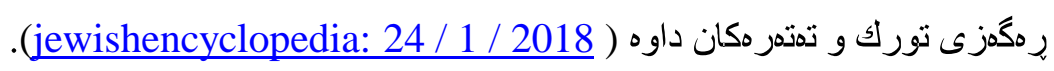




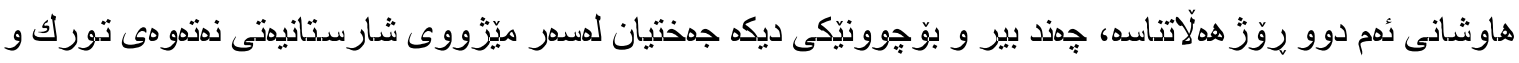

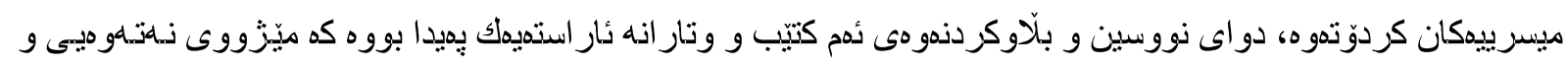

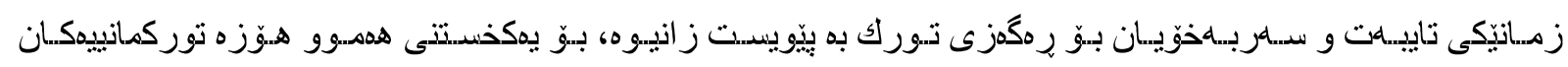

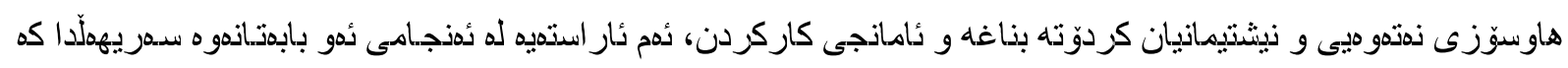

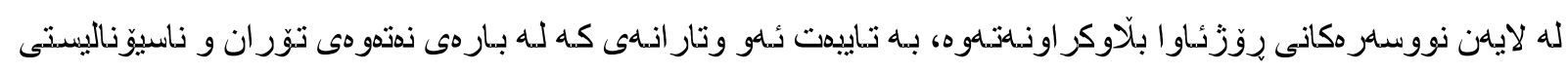

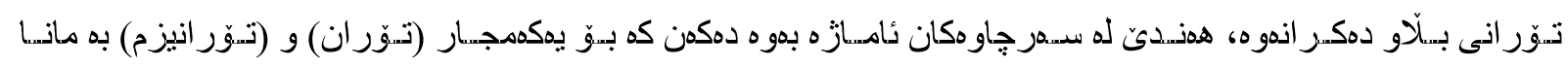

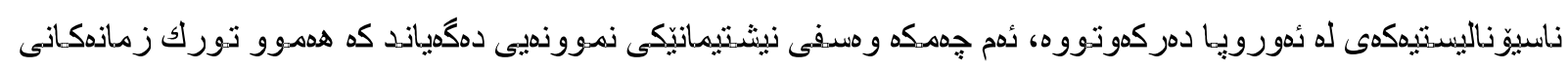

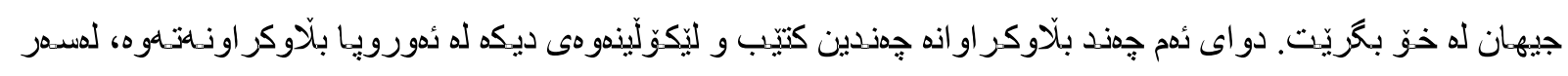

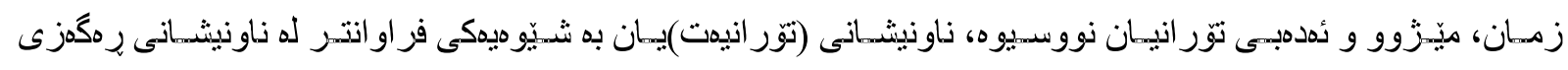

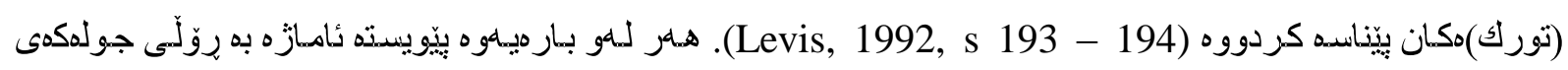

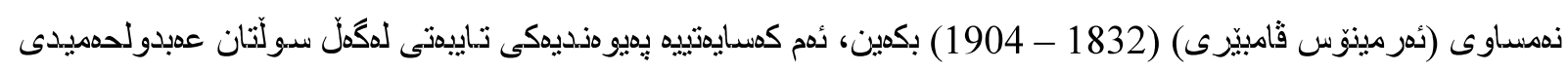

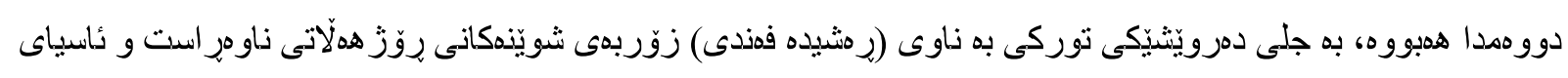

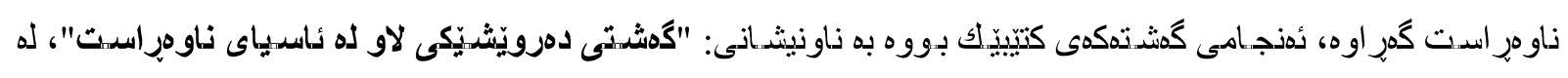

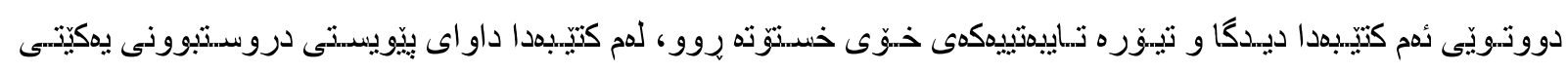

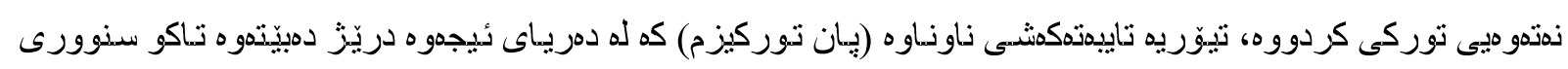

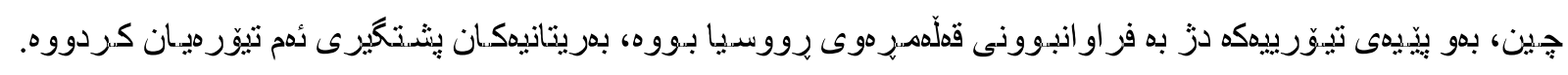

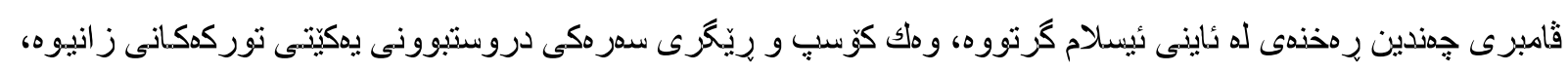

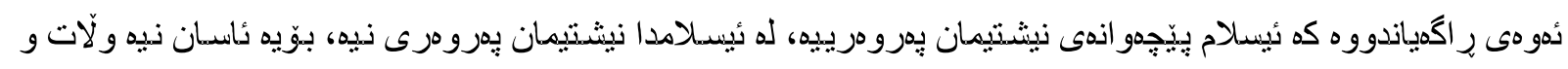

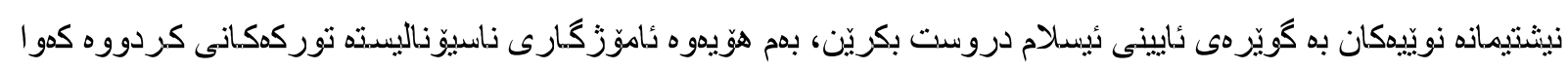

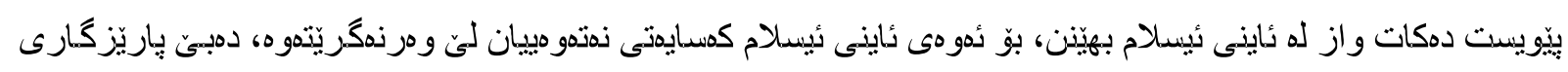

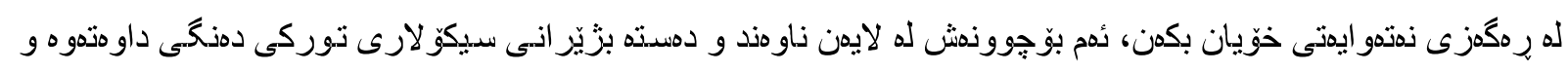

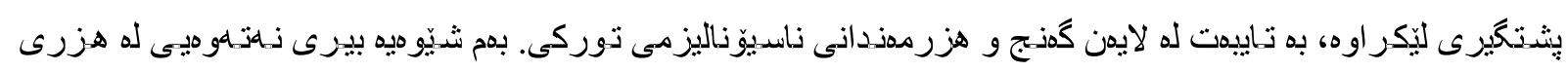

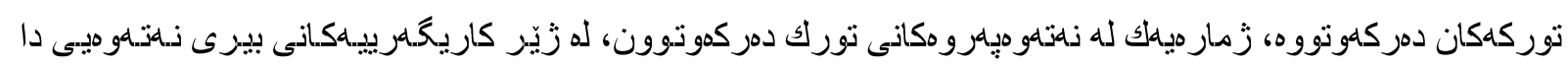

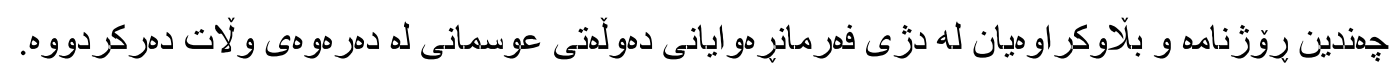

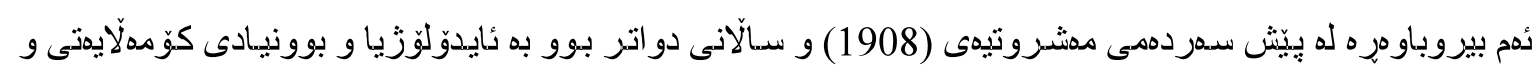

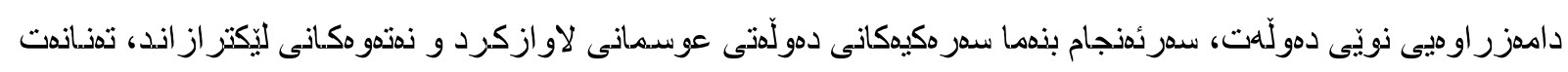

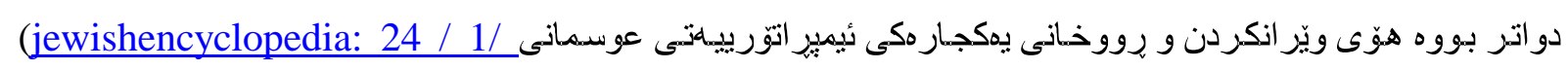

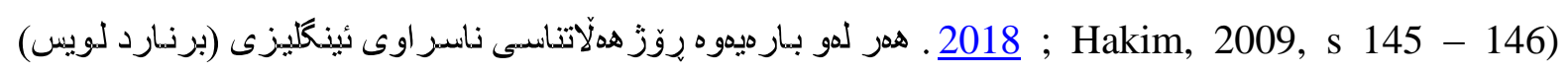

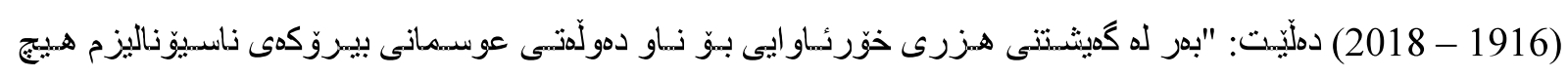

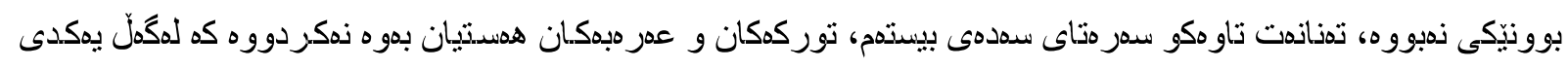

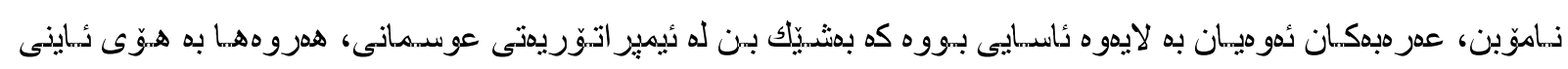

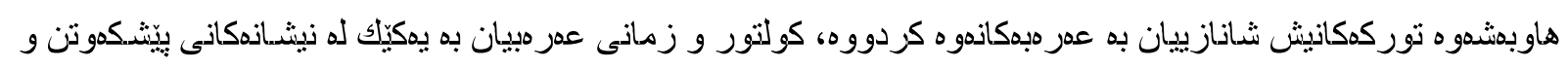

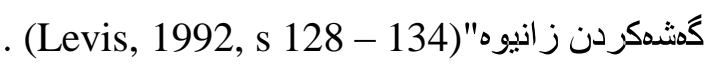




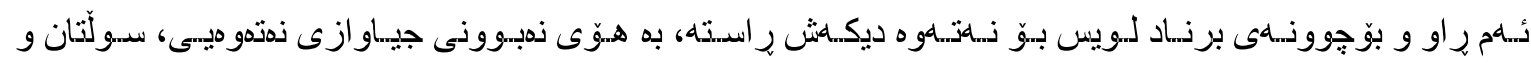

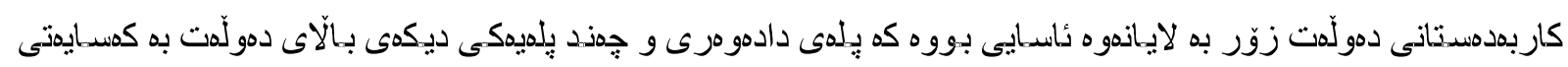

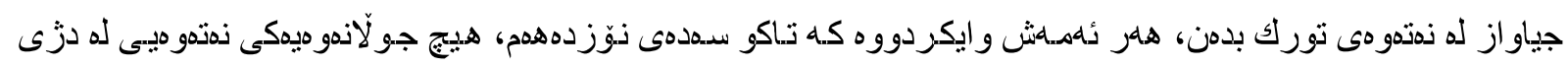

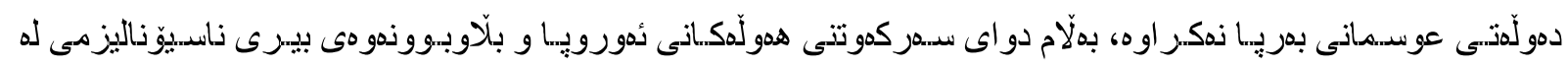

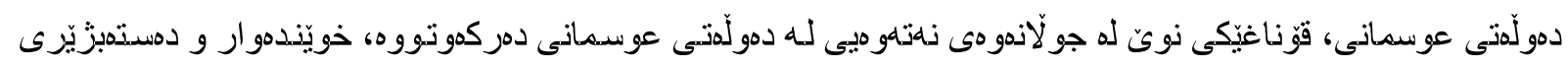

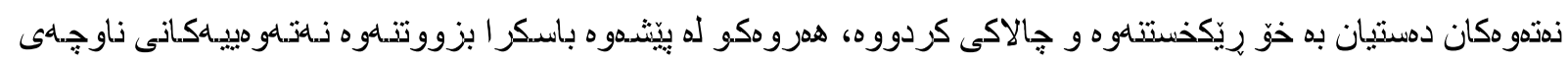

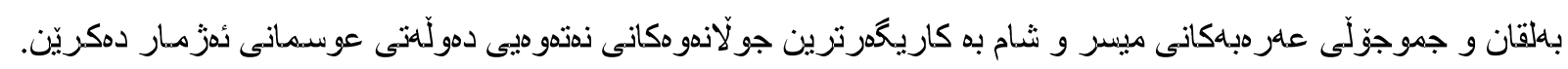

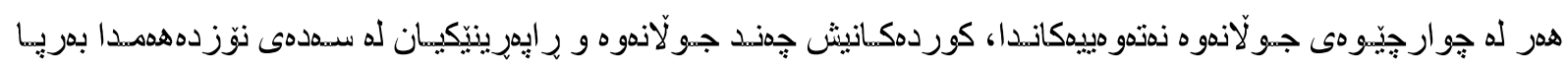

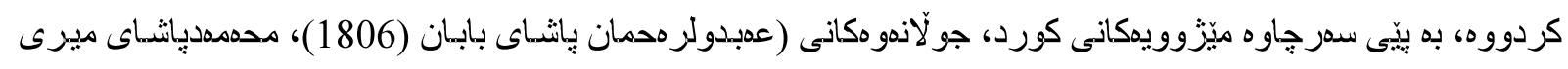

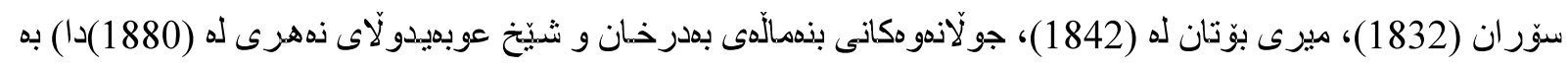

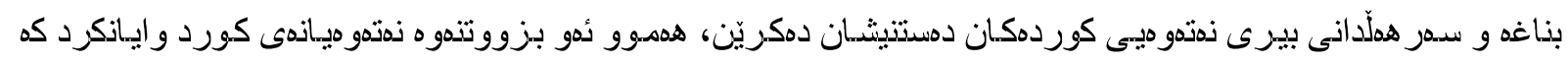

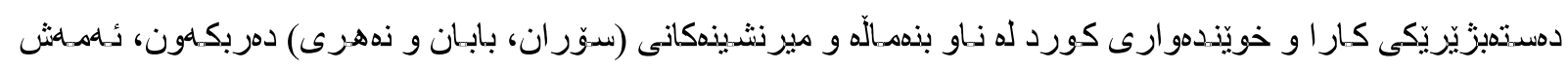

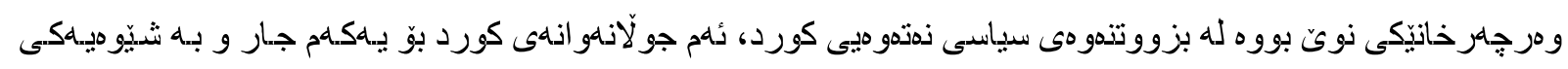

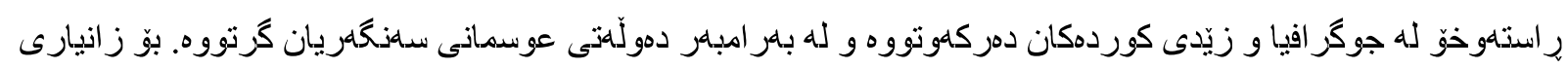

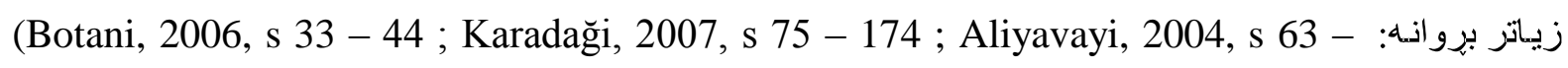

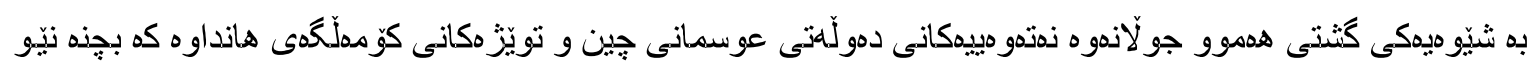

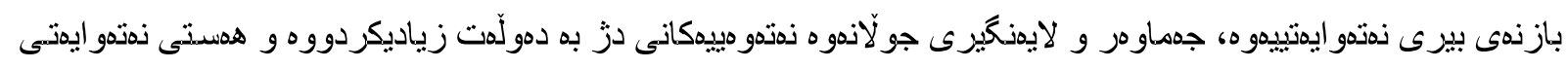

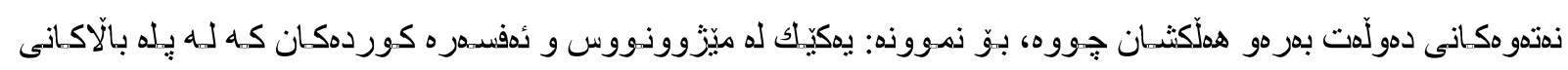

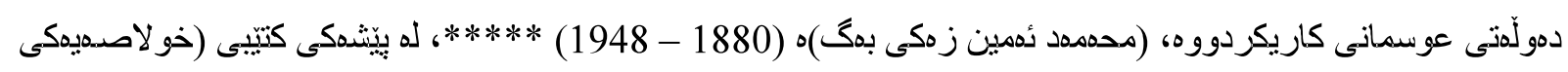
تاريخى كورد و كوردستان)دا دملّيت:

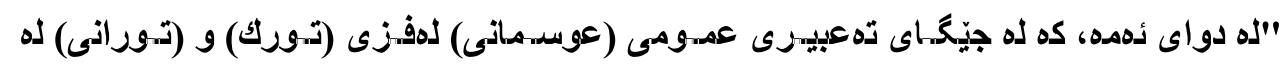

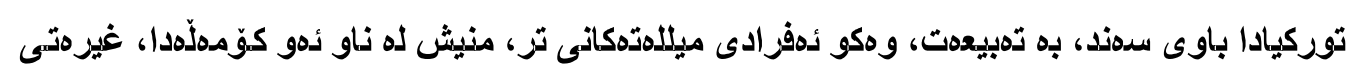

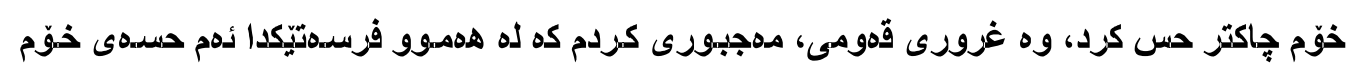

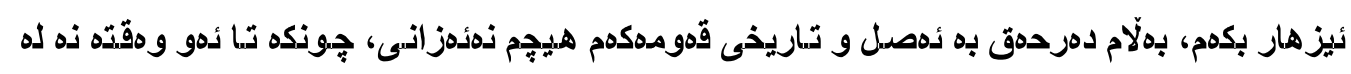

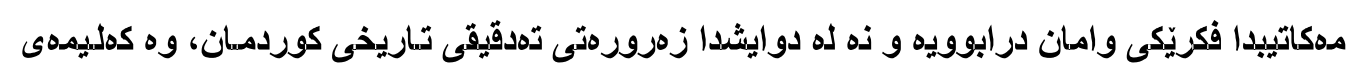

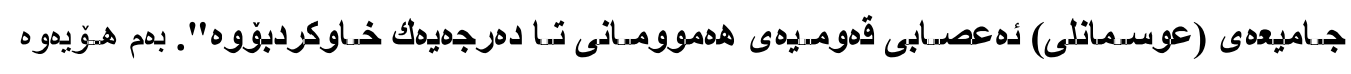

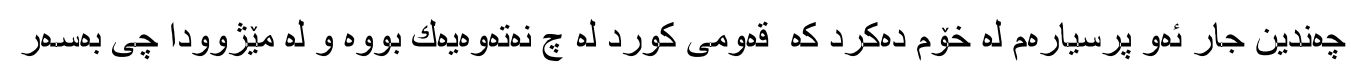

هاتووه (Zeki Bag, 2000, s 7).

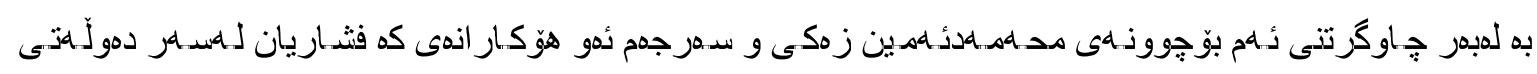

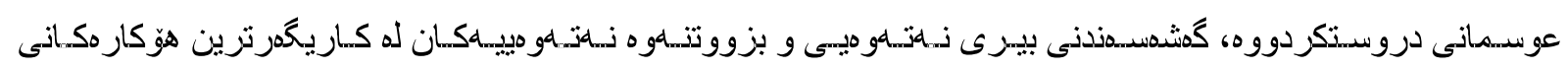

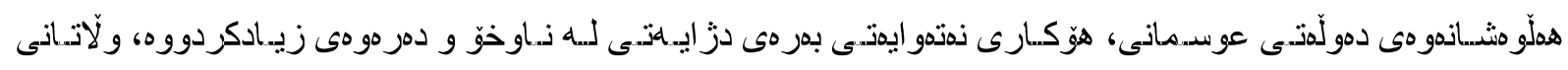

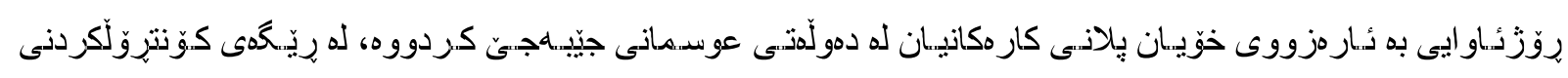

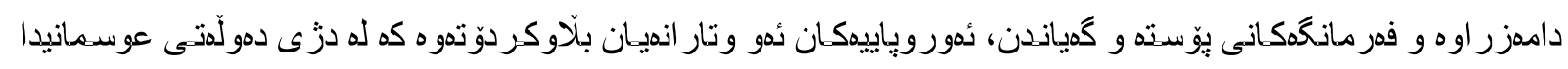




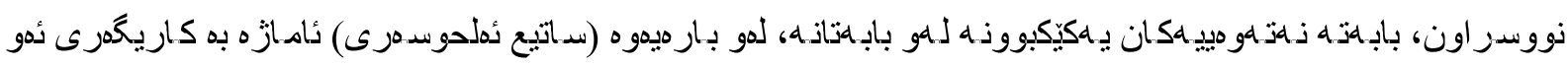

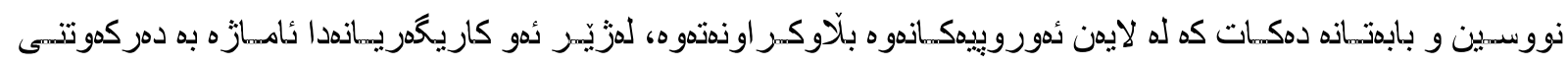

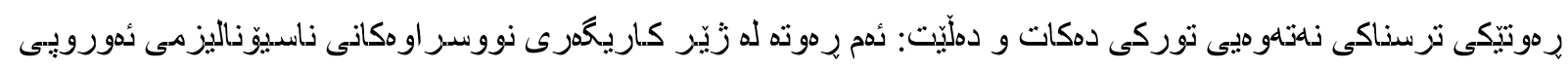

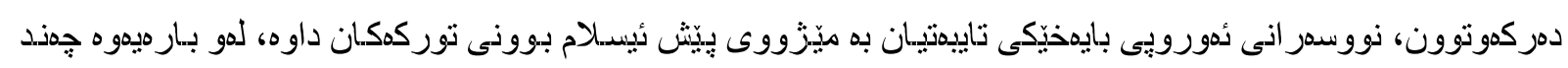

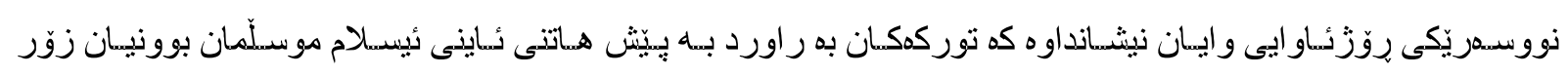

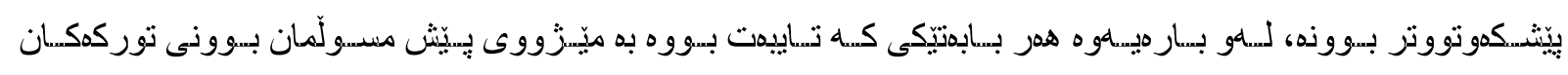

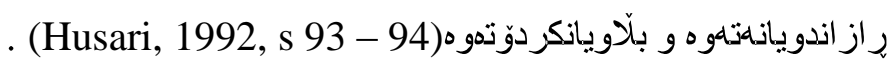

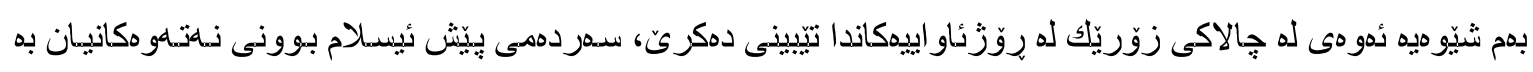

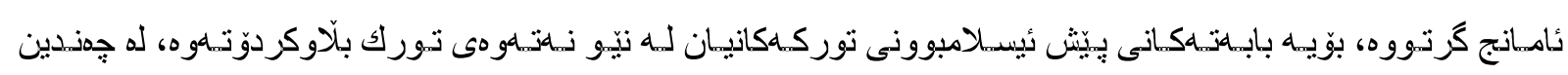

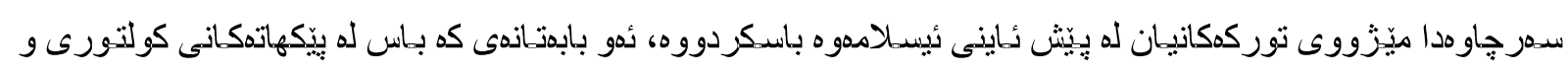

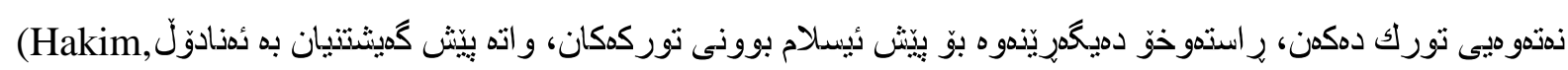

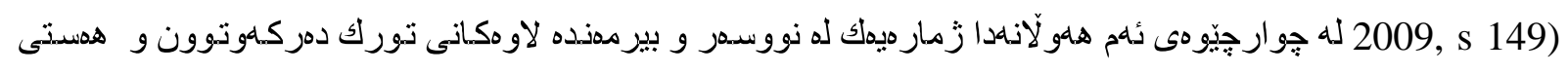

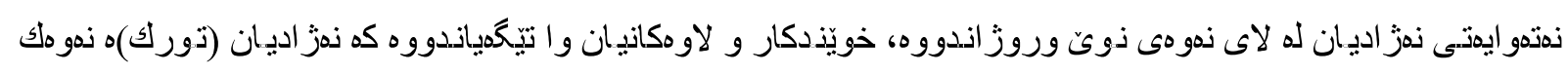

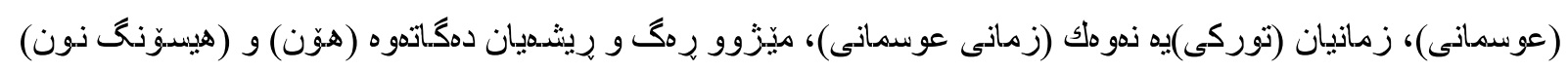

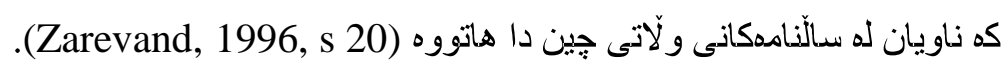

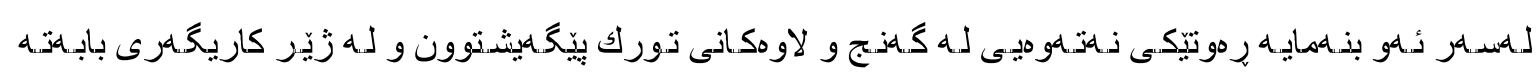

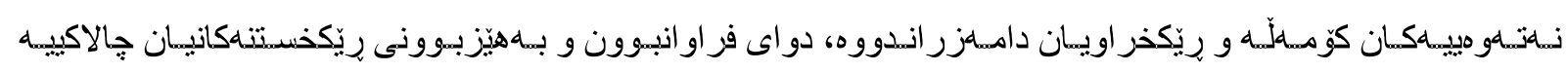

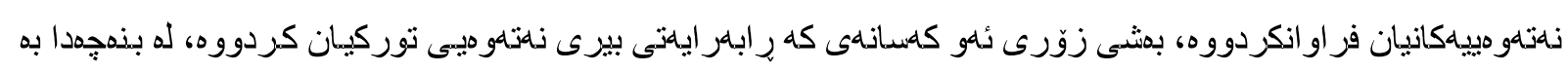

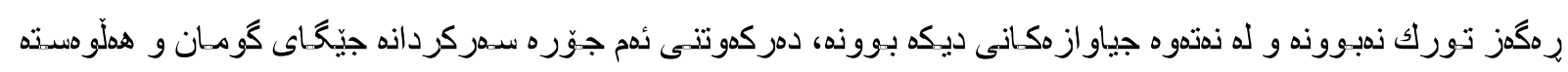

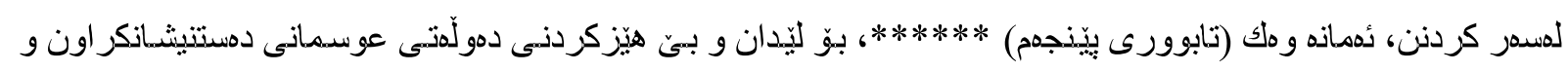

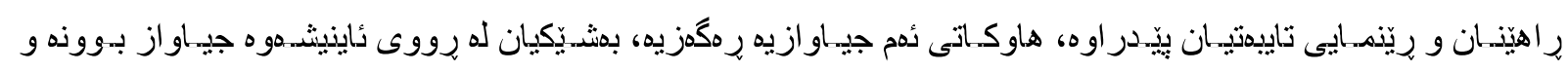

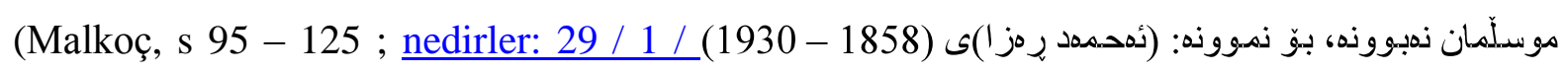

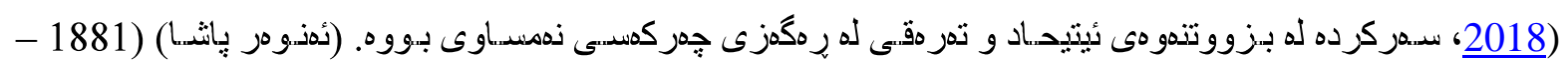

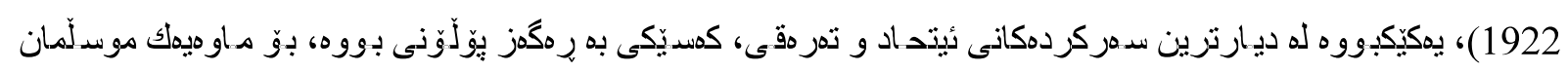

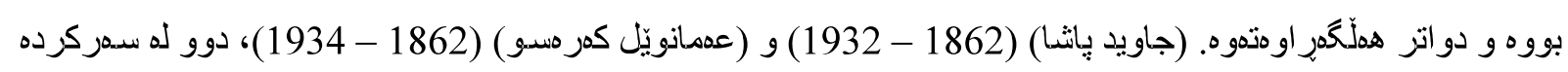

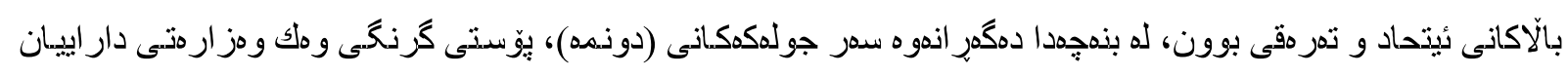

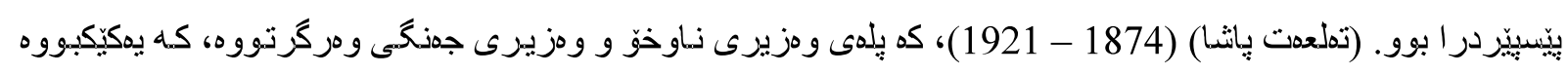

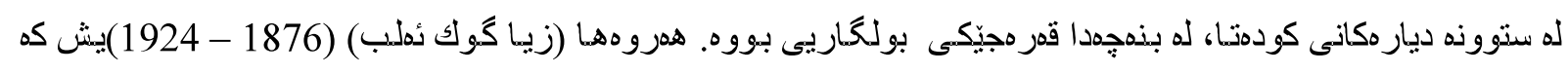

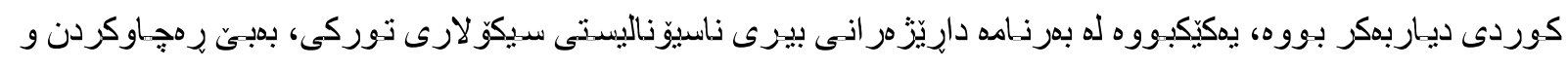

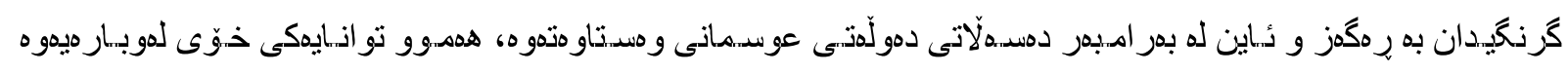

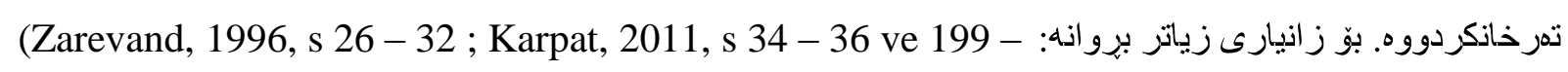

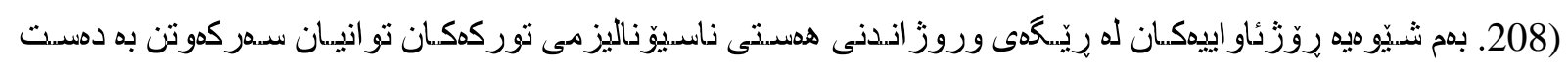

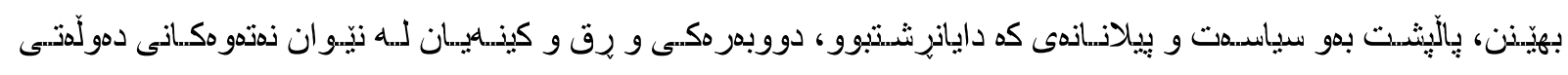

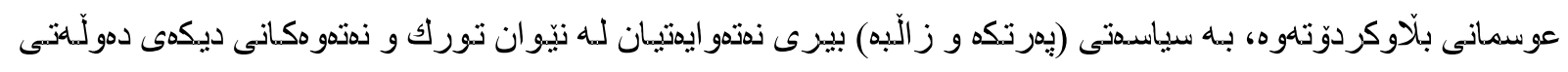




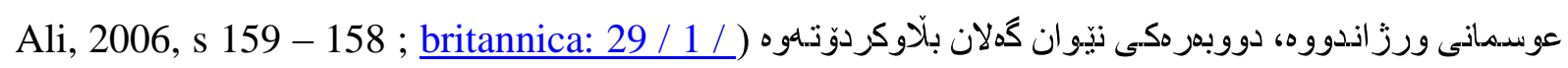

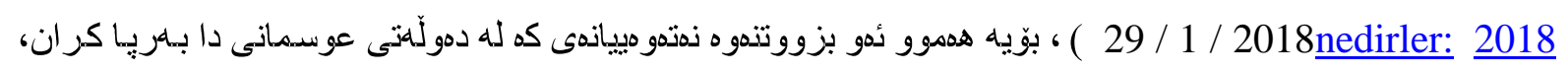

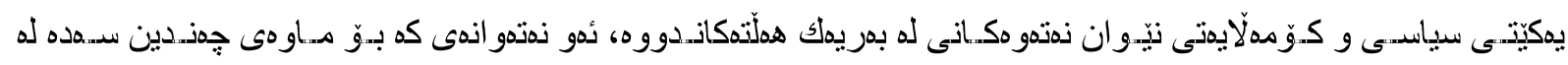

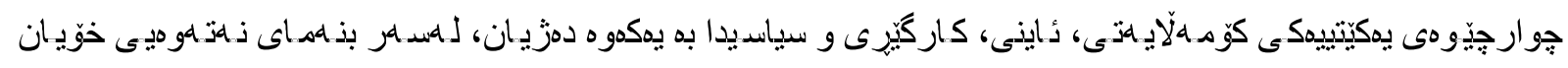

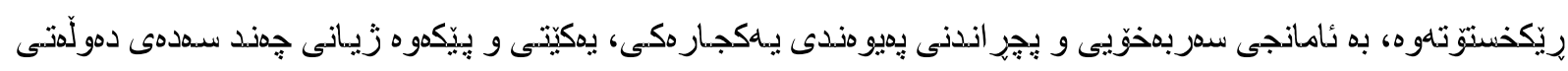

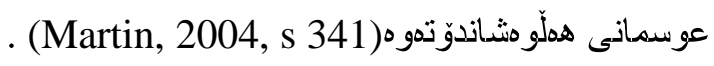

ئلذجامهكان:

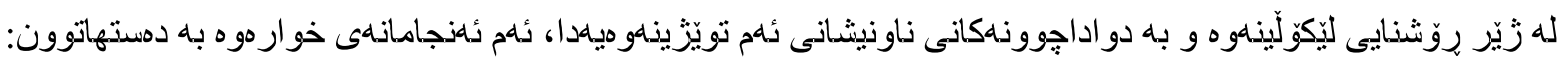

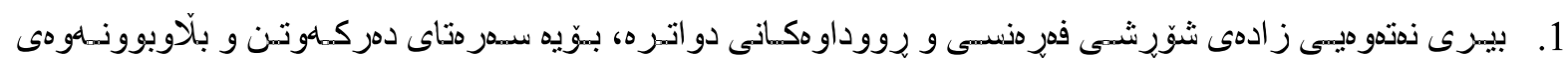

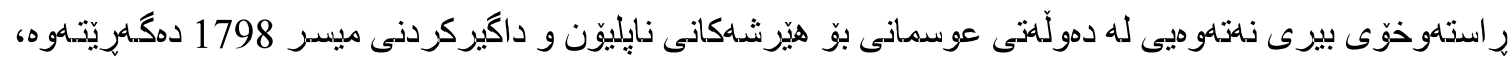

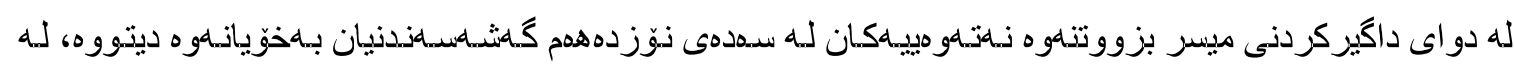

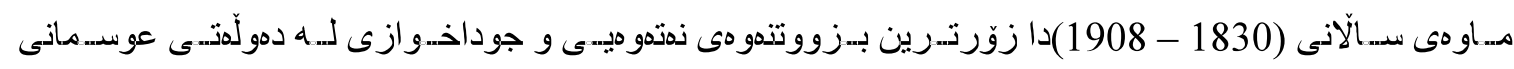
دمركموتوون.

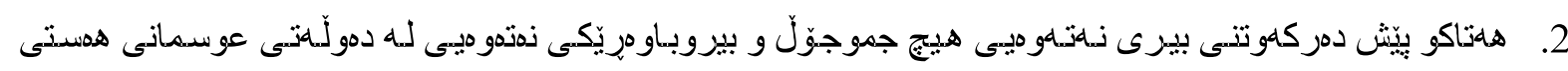

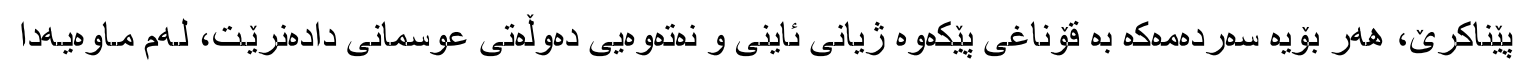

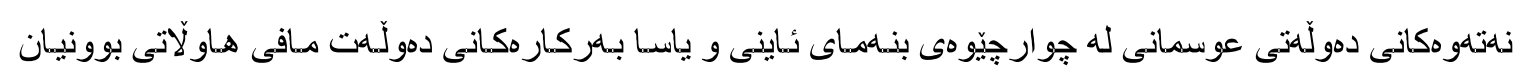
هلبووه.

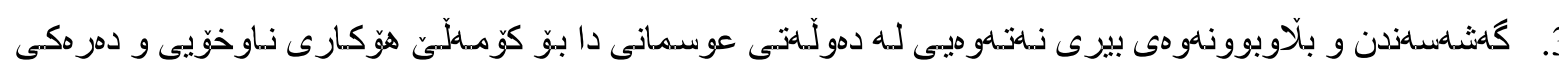

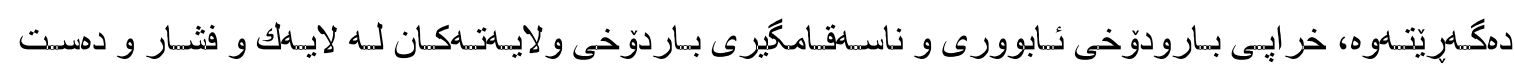

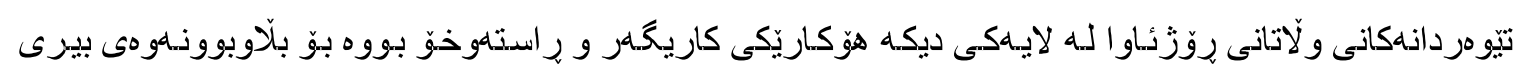

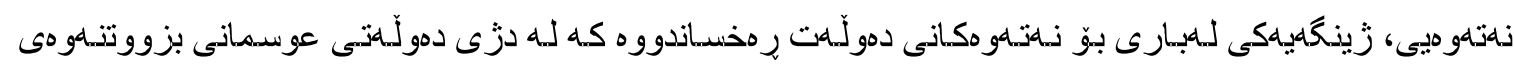
ذهنهو ايهنى بهريا بكهن.

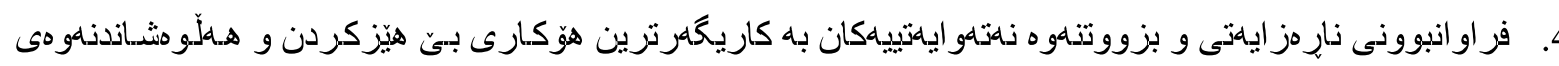

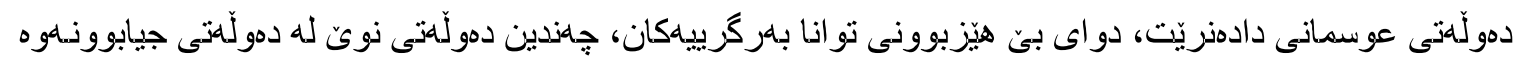
و لهسدر بذهماى ذهنهو ميى سذوورى ولّاتهكانيان دياريكرد. 


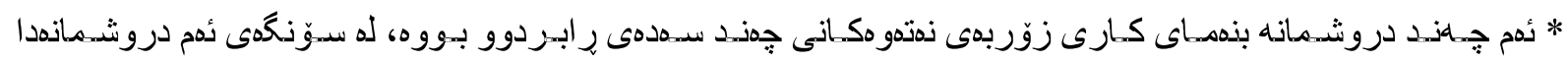

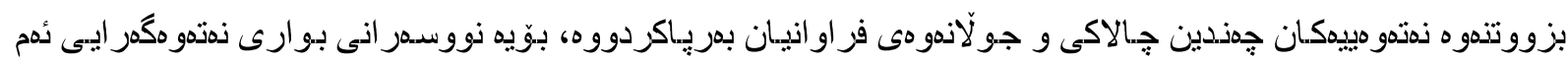
دروشمانديان به بذهماو هيّماى بيرى ناسيوّناليزم ناساندووه (تويّزّهر ).

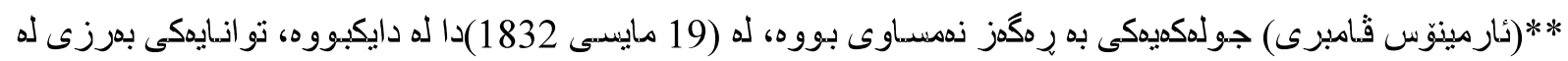

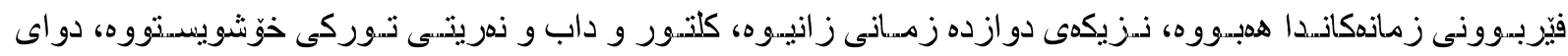

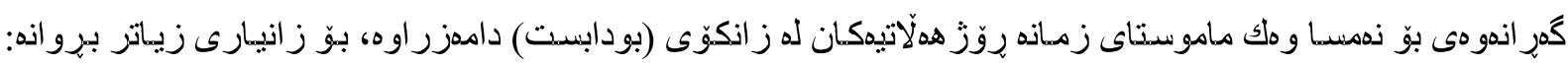
. (3/4/2018 findagrave:)

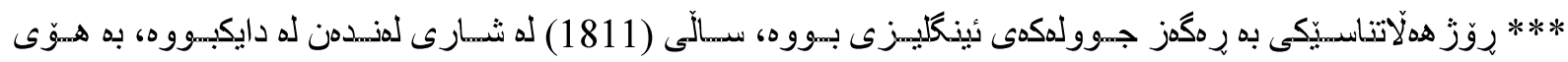

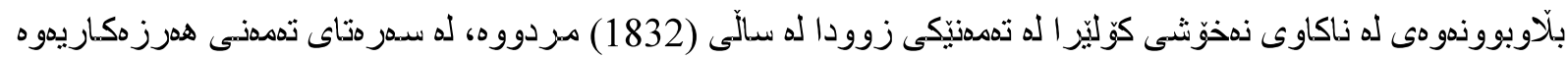

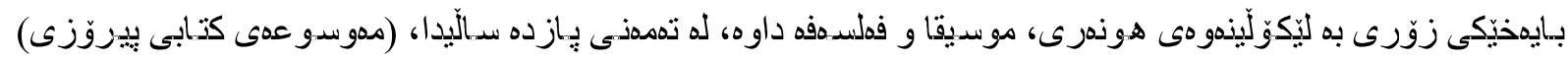

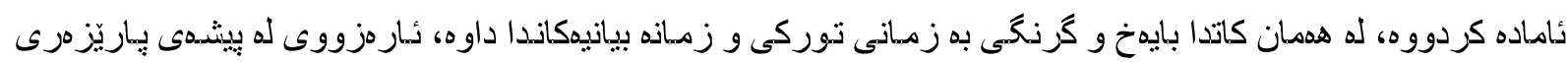

بووه و دهنتى به بيشهى باريّزهرى كردووه. ( 24 / 1 / 2018jewishencyclopedia:

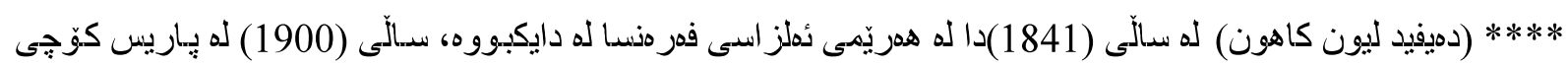

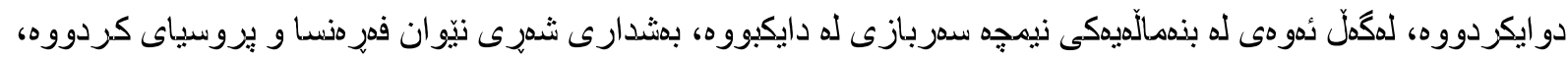

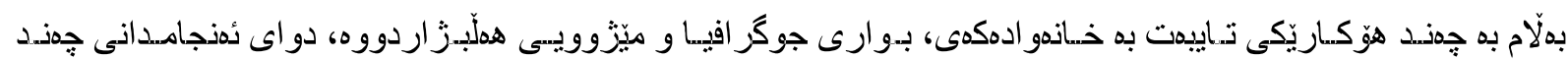

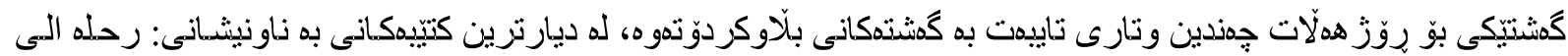

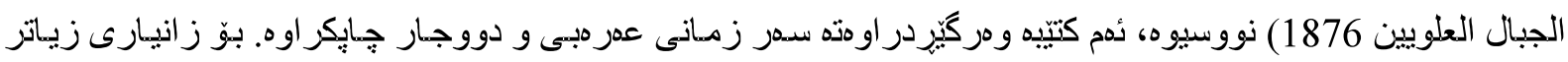

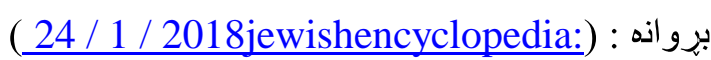

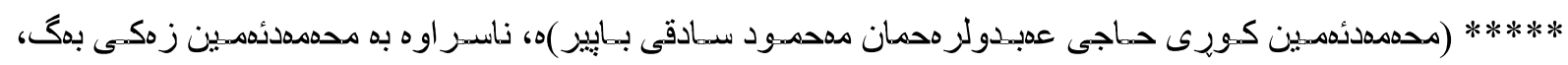

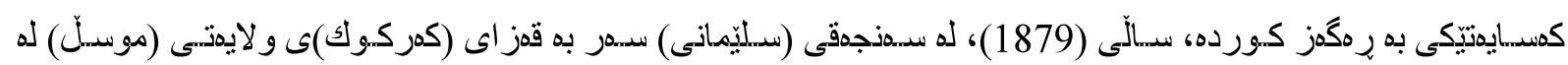

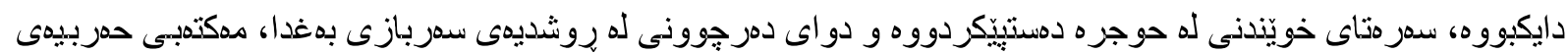

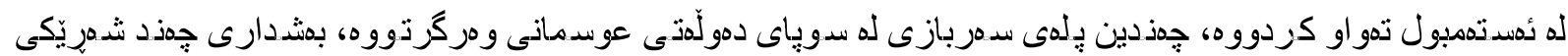

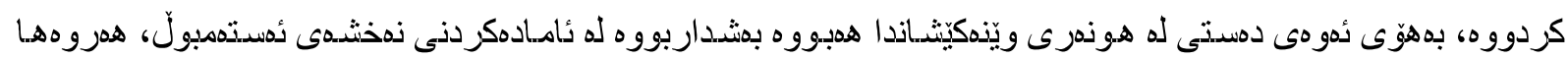

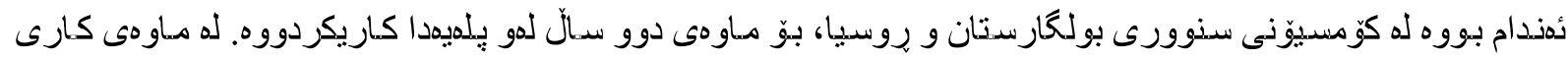

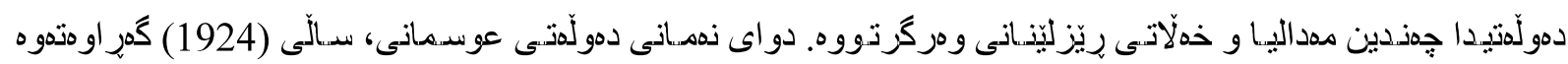

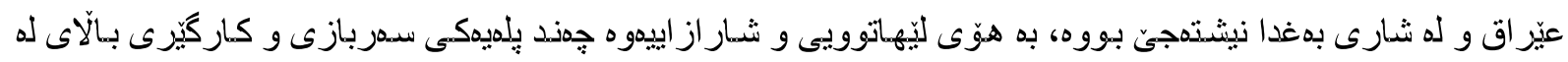

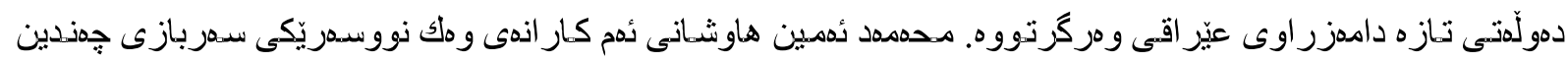

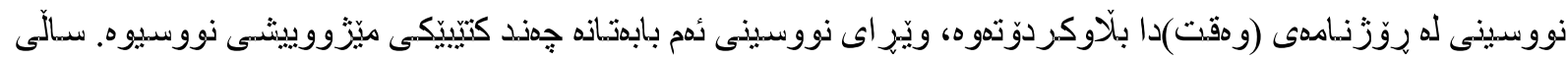

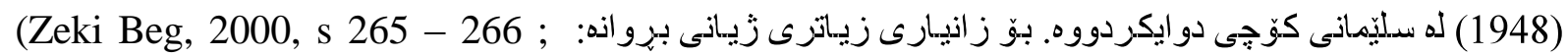

.Salih, s $6-9)$

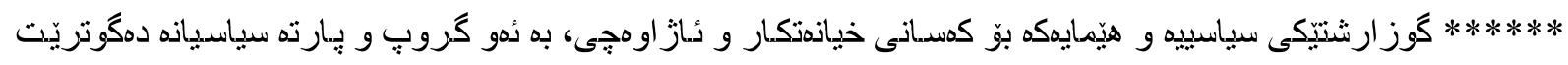

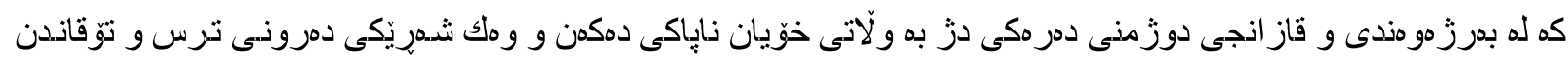

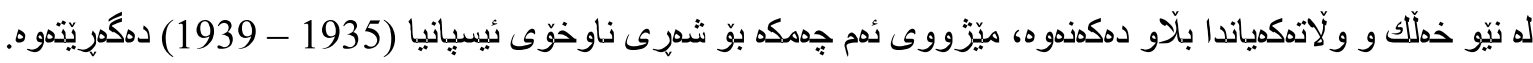




\section{Serçavekan}

\section{A: Ktêbekan}

A'zavi, Keyîs Cavad el-A'zavî (2003). el-daule el-Osmanîye Karaa Cedîde Lila'uaml İnhitat, taabaa sanîye, Beyrut.

Abdulhalik, Mesud, (2008). Mavsua'i Cudî, Çapî Yekem, Blavkravey Nûsîngey Tefsîr, Erbil. Abdulkarîm, Ahmad, (1970). El-kaumîye val mazahib el-siyasîye, matbaa elskafîye, Kahire.

Abdulvahab el-Kayalî, (1990). Mausaa el-siyasîye, tabaa salisa, Beyrut.

Abrîşemî, Abdulla Abrîşemî, Netevehvazî, Vergêranî: Selahedîn Aştî, Çapî Yekem, Çaphaney Şvan

Ahmad, İbrahîm Halîl, (2005). Tarîh el-vatan el-a'rabî Fîl a'hd osmanî 1516 - 1916, Dar İbn asîr Liltiba'a valnașr.

Akgündüz, Ahmed, (2014). El-vasayik Tntk Bilhakayek, İmak ofsît, İstanbül

Ali, Osman, (2011). El-haraka el-kürdîye el-ma'asr dirasat Tarîhîye vsaikîye1833 - 1946, tabaa sanîye, maktabe el-tafsîr Lilnaşr valilan, Erbil.

Aliyaveyî, Abdulla, (2004). Kürdistan Leserdemî Devletî Osmanîda Le Naverastî Sedey Nozdehemeve Ta Cengî Yekemî Cîhan, Senterî Lêkolînevey Stratîjî Kürdstan, Slêmanî.

Baktiaya, Adil, (2017). Osmanlı Suriyesi'nde Arapçılğın Doğuşu Sosyal - Ekonomik Değişim ve Siyasi Düşünce, 1. Baskı, İletişim Yayınları, İstanbul.

Botani, Abdulfetah Ali, (2006). Seretakanî Hestî Netevayetî Kurd Le Mêjuuy Nvêda, Vergêranî: Selah Omer, Çapî Yekem, Çaphaney Minare, Hevlêr.

Bozarsalan, Hamit, (2015). Ortadoğu: Bir Şiddet Tarihi Osmanlı İmparatorluğu'nun Sonundan El-Kaiyde'ye, Çeviren: Ali Berktay, 4. Baskı, İletişim Yayınları, İstanbul.

Buyid, Şîfer, (1966). El-kaumîye (A'rz Va tahlîl), Tercüme: Ca'far Hasbak va A'dnan elhumeyîrî, Dar Maktaba el-hayat Bilmşarka Maa' Mosasa Franklin, Bagdad - Nîvork.

Ca'fer, Alî, (2013). Nasyonalîzm Û Nasyonalîzmî Kurdî, Çapî Duvam, Çaphaney Rojhelat, Hevlêr.

Corc, Antonîyos, (1987). Yakza el-arabiye, Tercüme: Dr. Nasraldîn Asd va Dr. İhsan A'bas, tabaa samina, Daru A'lam Lilmlayîn, Beyrut.

Cvrî, Bravn, (2009). Puhtey Mêjuuy Eurupa Le Koneve Ta Emro, Vergêranî: Nihad Celal Hebîbu Allh, Çapî Yekem.

Dabağyan, Levon Panos, (2011). Sultan Abdülhamid Han ve Ermeniler, 3. Bask1, Kum Saatı, İstanbul.

Darîvş, Aşurî u Dr. Bahadîn Pazargad, (2011). Ferhengî Nvê, Vergêranî: Burhan Kanii', Çapî Çvarem, Slêmanî.

Davids, Arthur Lumley, (2013). Türk Dili Grameri, Çeviren: Serdar Yavuz Diğerleri, Birnci Baskı, Yayınevi, Nobel Akademik Yayıncılık.

Donald, Kuataert, (2005). The ottoman empire 1700-1922, second edition, Cambridge University.

Donald, Kvatrt, (2004). El-davla el-osmaniye 1700 - 1922, Tercüme, Aymen el-Arminazî, Maktaba el-A'ubeykan, Ryaz.

Elbêrt, Îsa, (2008). Nasyonalîzmî A’rabî Le Împratoryetî Osmanyeve Bo İrakî Serdemî Faşîzm, Çapî Yekem, Çaphaney Sardam, Slêmanî.

El-müncid fî elluğa val aa'lam, (2012). Tabaa el-hams val arbaa’un, dar almişk, Beyrut.

Endo, Vînsînt (2007). Aydolojiya modêrne siyasîyekan, vergêranî: Omer Mevludî, çapî yekem, çaphaney Mukryanî, Hevlêr. 
Eriksen, Thomas Hylland, (2004). Etnisite ve Milliyetçilik Antropolojik Bir Bakış, Çeviren: Ekin Uşaklı, 1. Baskı, Barış Matbaacılık, Istanbul.

Fatih, Akın (2006). Türkiye'de Azınlık Politikaları 6 - 7 Eylül Olayları, 1. Baskı, Kum Saati, İstanbul.

Fazil, Hüsen Û D., Kazm, Haşm Na'me, (2012). Mêjuuy Nvêy Eurupa 1815 - 1939, Vergêranî: Mustafa Sa'îd Alî, Çapî Dvam, Çaphaney Çvarçra.

Garib, Hassan H., (2000). Fî Sabîl İlaka Slmiye Beyîne A’ruba Val İslam Bahs Fî Tarîh Val aydolociya, tabaa Avla, Dar el-tulayaa' Liltibaa' Valnaşr, Beyrut.

Güler, Ali, (2003). Osmanlı Cumhuriyete Azınlıklar, Bask1 Poyraz Ofset, Ankara.

Hatum, Nuradîn, (1967). Tarîh el-Harakat el-Kaumîye, el-Tabaa' Avla, Darulfikr el-hadîs, Lübnan, Cüzü 1 .

Husari, Abu Haldun Sati, (1985). Ela'ruba Avlan, tabaa' sanîye, Markaz Dirasat el-vahda Arabîya, Beyrut.

Husari, Abu Haldun Sati, Muhazrat Fî Nşu el-fikre kumîye, tabaa' sanîye, Merkez Dirasat elvahda A'rabyîe, Beyrut.

Karadaği, A’ta Karadaği (2007). Gutarî Nasyonalîzmî Kurdî, Çapî Yekem, Çaphaney Renc, Slêmanî.

Karpat, Kemal H., (2011). Osmanlı Günümüze Ortadoğu'da Millet, Milliyet, Milliyetçilk, 1. Baskı, Timaş Yayınları, İstanbul.

Komelêk, Nûser, (2017). Nasyonalîzm Rêbazêkî Siyasî Bo Bniyatnanî Vlat, Çapî Yekem, Çaphaney Serdem, Slêmanî.

Levis, Bernard Levis, (1992). Islam in history (ideas, people, and events in the Middle East, second edition, Chicago.

Malkoç, Eminalp, (2007). Doğu - Batı Ekseninde Bir Osmanlı Aydını: Ahmet Rıza Yaşamı ve Düșünce Dünyas1

Martin, Richard C., (2004). Encyclopedia of Islam and the Muslim Vorld, Macmillan Reference, United States of America.

Michael, Rundell, (2007). Macmillan Engish Dictionary, second edition.

Ortaylı, İlber, (2013). İmpratorluğun Son Nefesi Osmanlı'nın Yaşayan Mirası Cumhuriyet, 3. Baskı, Timaş Yayınları, İstanbul.

Oxford Dictionary, (2007). Third edition.

Razvan, Valîd, (2006). El-I'lakat el-A'rabîye el-Türkîye, tabaa aval, Lübnan.

Sino, A'bdulrauf, (1998). El-Nza'at el-kiyanîya el-İslamîye Fî el-daule el-Osmanîye 1877 1881, Bilad Şam, Hicaz, Kürdistan, Albaniya, Taba'a avla, Bîsan Lilnaşr Valtauzî', Bîrut.

Slti, Süheyir el-tel, (2002). Haraka el-kaumîyîn A'rab Va İna’tafatha el-fkrîye, tabaa sanîye, Markaz Dirasat el-vahda Arabîy'a, Beyrut.

Sofuoğlu, Ebubekir, (2014). Balkanlar'da Kuşatma Var, 1. Baskı, Babıali Kültür Yayıncılı̆̆ı, İstanbul

Studard, Lusrub, (1973). Hazr A'lam el-İslamî, Tercüme: A'Cc Nuiyhez, tabaa rabiya'a Beyrut, Cild 2.

Şahabadîn, Abu A'mru, (2005). El-muncid, tabaa avla, Beyrut.

Tahsin, Paşa, (2007). Sultan Abdülhamid Tahsin Paşa'nın Yıldız Hatıraları, Beşinci Baskı, Boğaziçi Yayınları, İstanbul.

Türk Dil Kurumu, (1988). Türkçe Sözlük, Türk Tarih Kurumu Basım Evi, Ankara, Cilt 2.

Zahır, Ahmad Cemal, (1988). Dirasat Fî falsafe elsiyasiye, tabaa' eval, Dar va Maktaba elkndî, Arbd.

Zarevand, Zarevand, (1996). Turançetî u derkevtn, Aydolojiya Û Bername, Vergêranî: Ebubekir Hoşnav, Çapî Yekem, Hevlêr. 
Zekî Beg, Muhammad Emîn, (2000). Hulaseyekî Tarîhî Kurd Û Kürdistan, Çaphaney Serdem, Slêmanî.

\section{B: Govarekan}

Hekîm, Ahmad, (2009). Derbarey serheldanî hzrî nasyonalizm, "Mêjû" (govar), jmare (12)î payzî.

Salih, Sdîk, Emîn Zekî Beg kêye, "Rovar" (govar), jmare (73), Slêmanî

\section{C: Pêge Elîktronîyekan.}

Hassan Halîl Garîb, el-a'vaml el-tarîhîye aletî ashamat fî̀ takvin el-fikr alkaumî el-a'rbî, http://arabrenewal.info $11 / 10 / 2018$.

Kamal Hamd, ya'kub Sanua' (1838 -1912): Aa'lamî yhudî Msrî nasr el-saura el-mahdîye, http://sudaneseonline.com $31 / 1 / 2018$.

https://www.findagrave.com 3 Nîsanî 2018

http://nedirler.com 29 kanunî duvemî 2018 .

http://www.Tdk.Gov.Tr 27/11/2017

http://www.tarihportali.org $20 / 1 / 2018$

http://www.jewishencyclopedia.com 24 / 1 / 2018

http://www.jewishencyclopedia.com 24 / 1 / 2018 .

http://nedirler.com 29 / 1 / 2018.

https://www.britannica.com/biography/Ziya-Gokalp 29/ 1 / 2018

http://www.osmanlidevleti.gen.tr 29 / 1 / 2018

https://www.marefa.org $30 / 1 / 2018$ 